\title{
Truce-Smiles rearrangement of substituted phenyl ethers
}

Joel R. Kosowan, Zemane W'Giorgis, Ravneet Grewal, Tabitha E. Wood*

Department of Chemistry, The University of Winnipeg, 515 Portage Avenue, Winnipeg, Manitoba, Canada, R3B 2E9

\section{Supporting Information}

Item

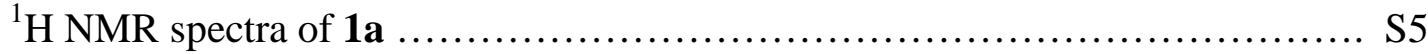

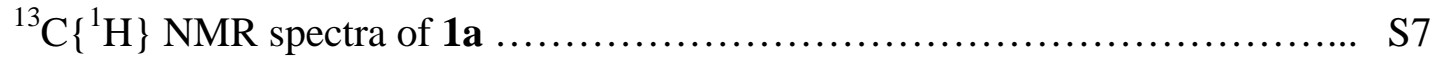

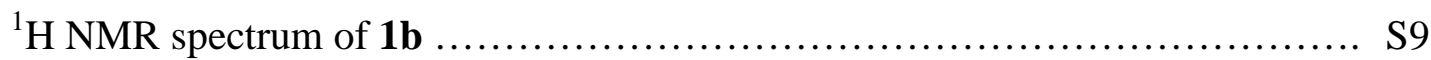

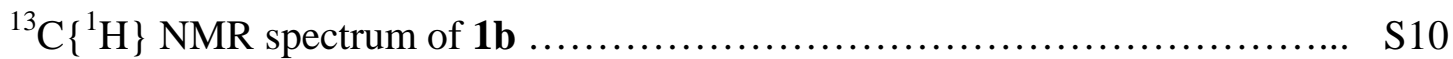

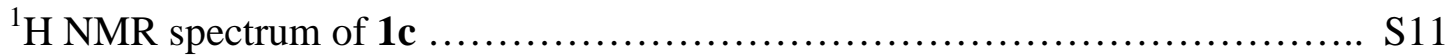

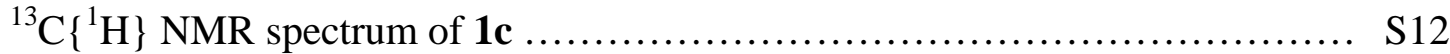

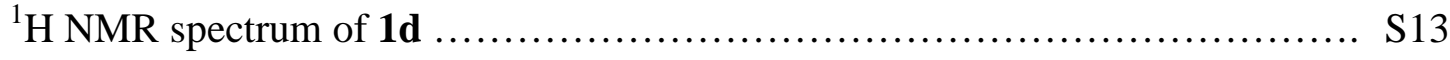

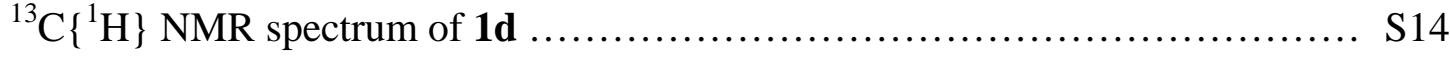

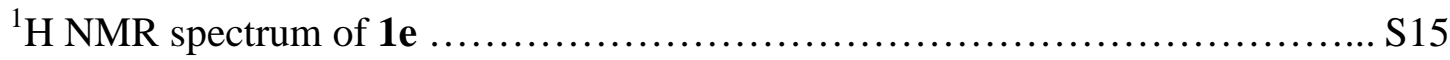

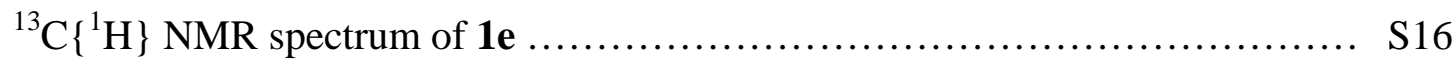

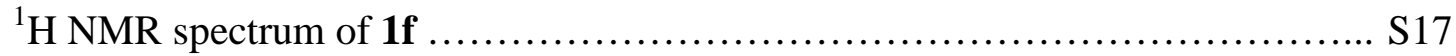

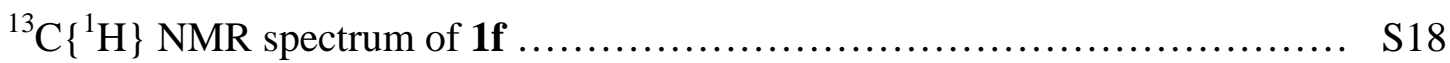

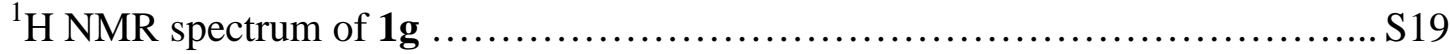

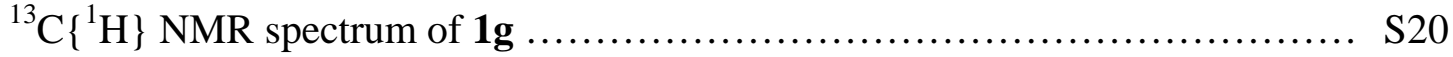

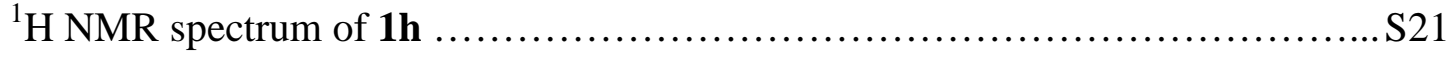

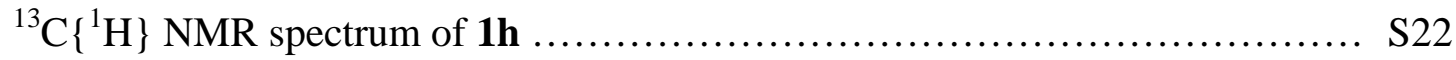

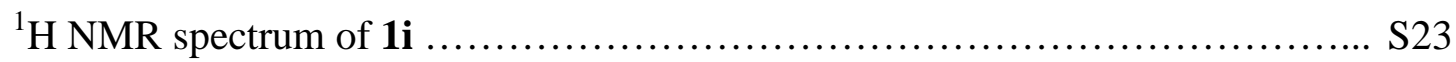

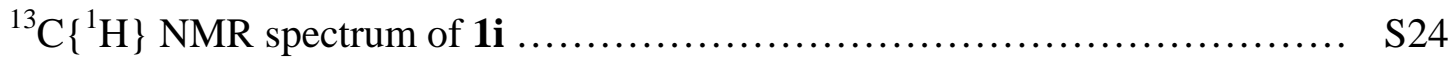




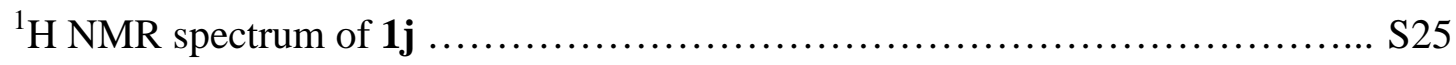

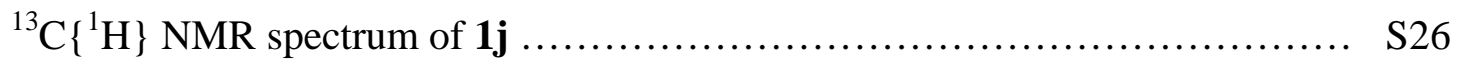

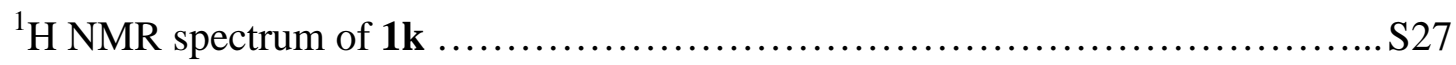

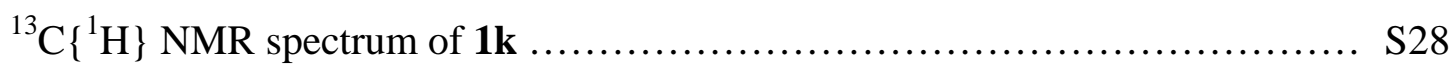

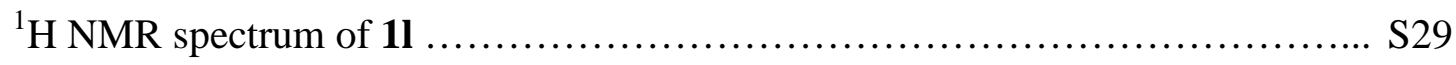

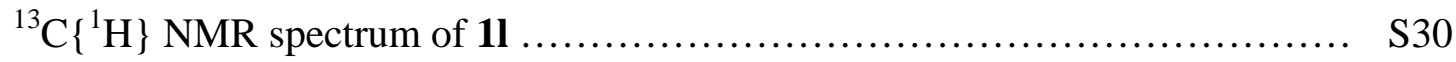

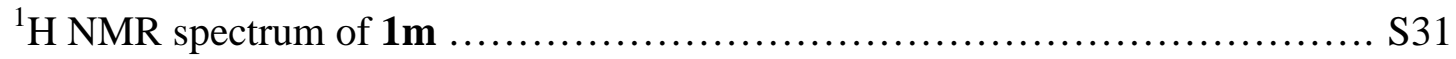

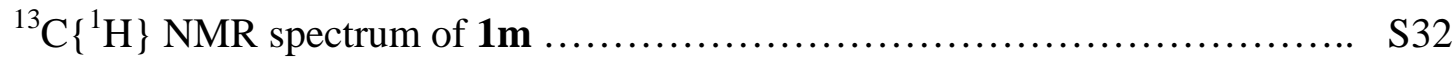

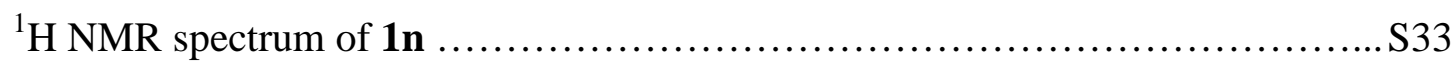

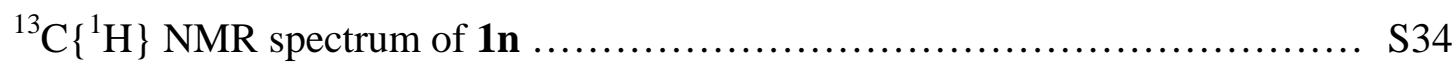

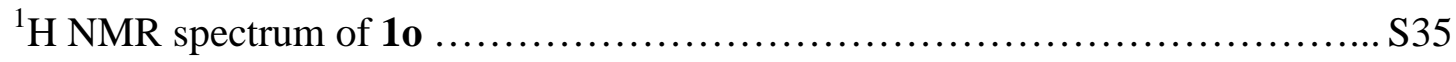

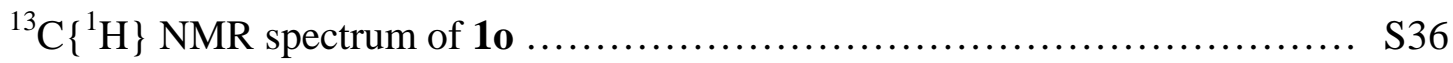

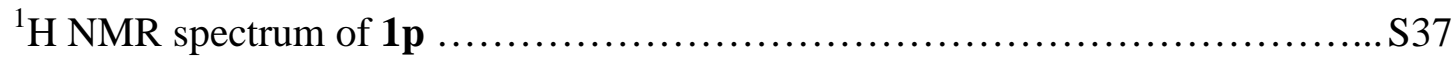

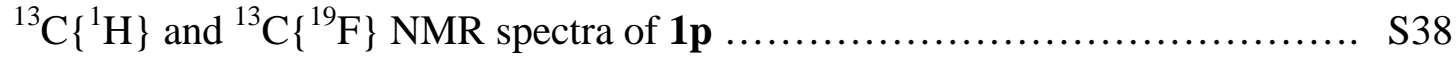

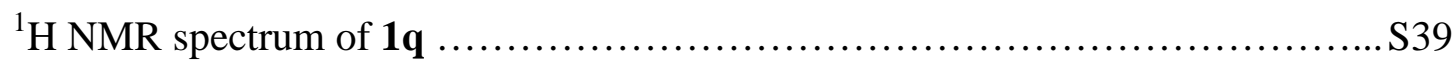

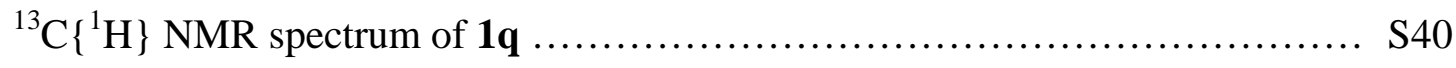

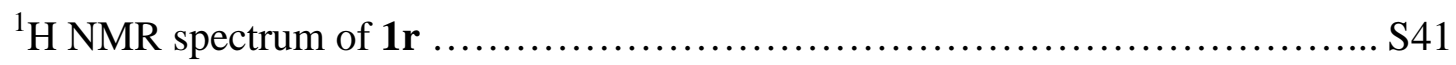

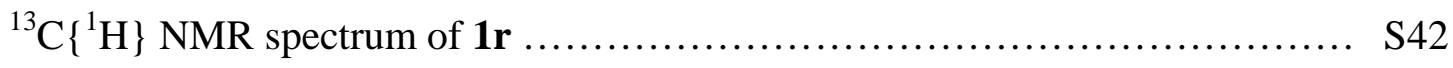

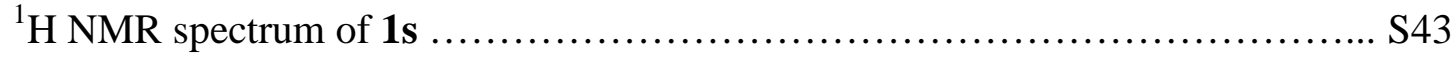

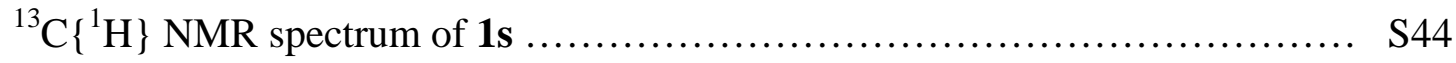

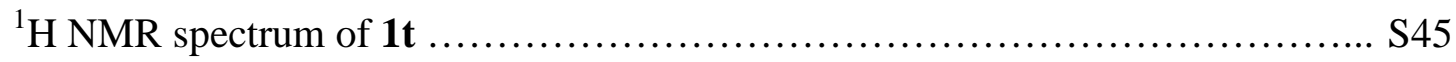

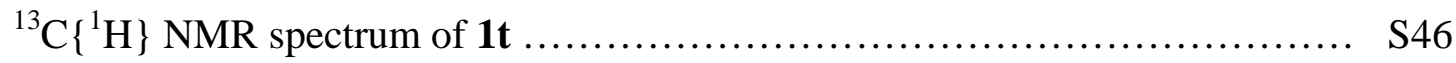

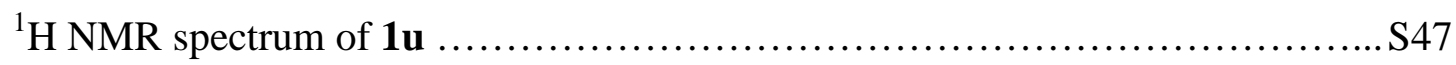

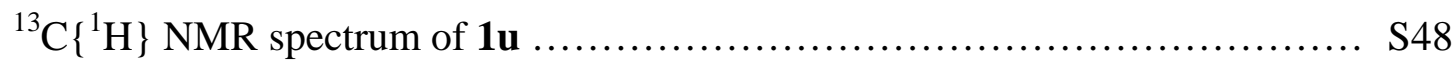

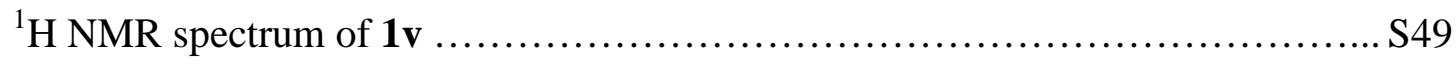




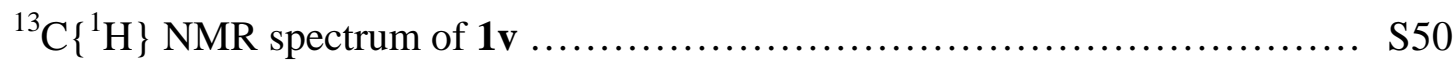

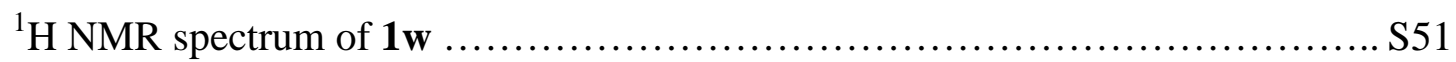

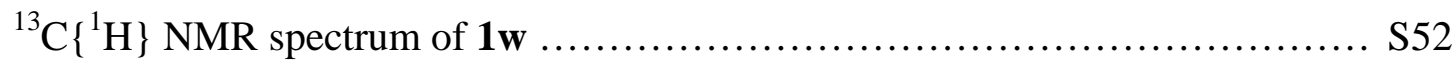

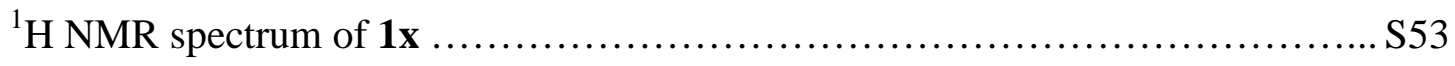

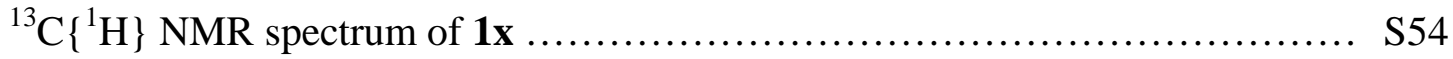

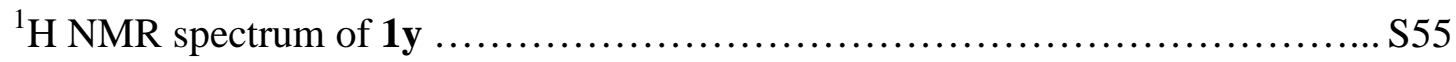

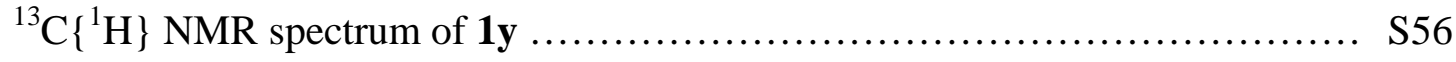

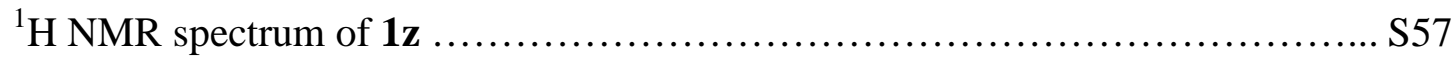

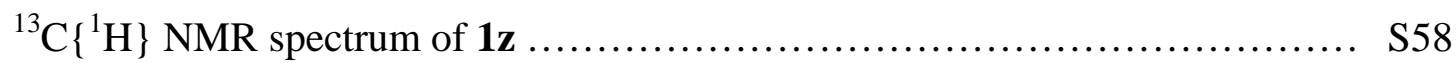

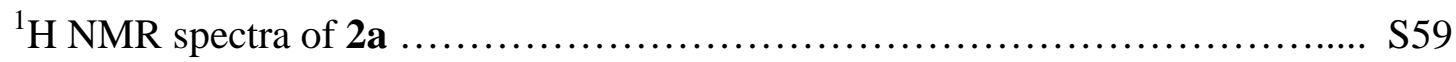

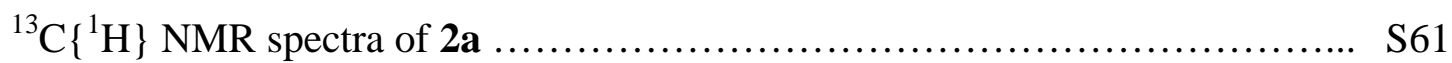

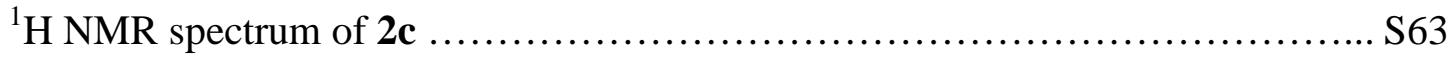

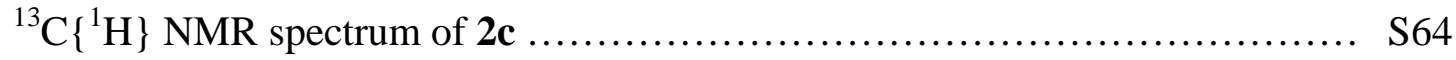

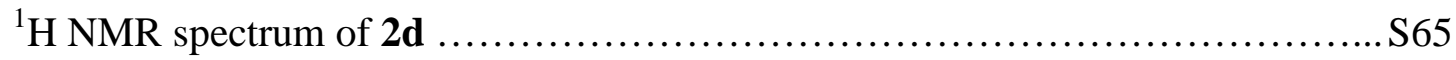

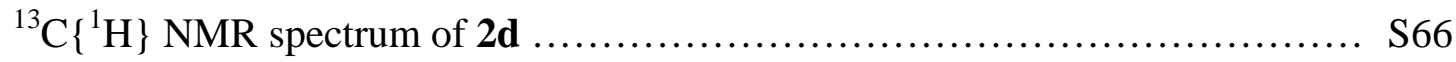

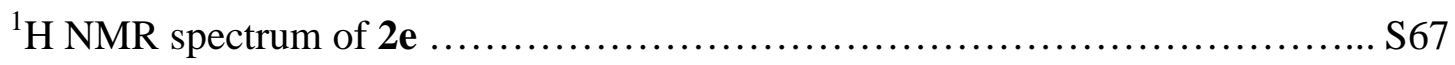

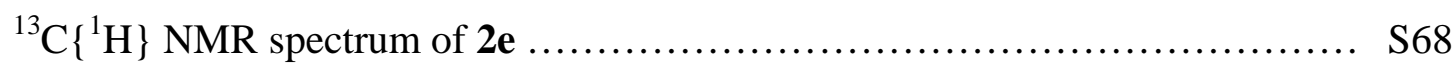

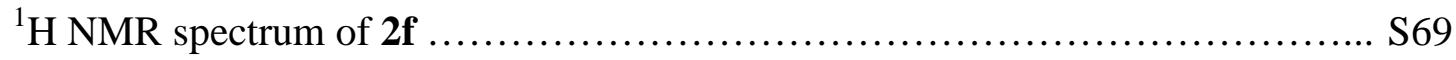

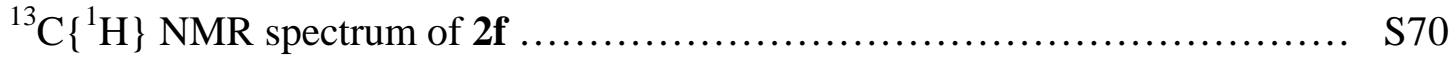

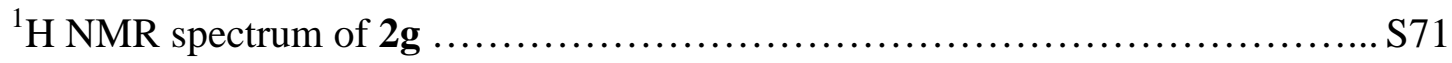

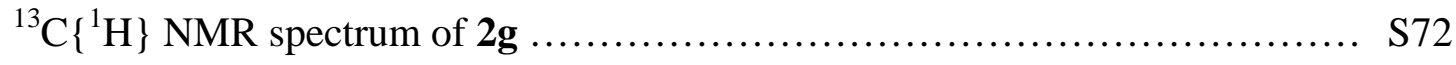

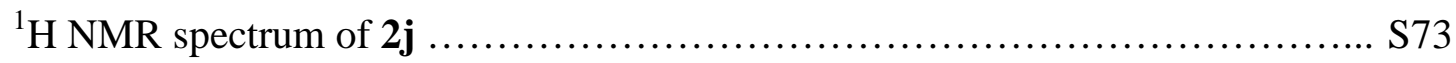

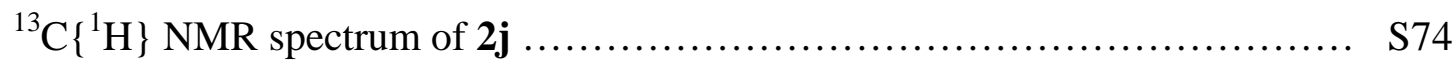

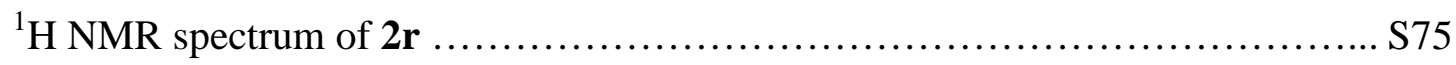

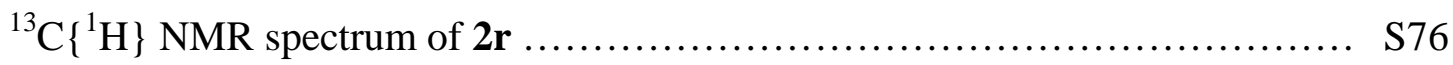




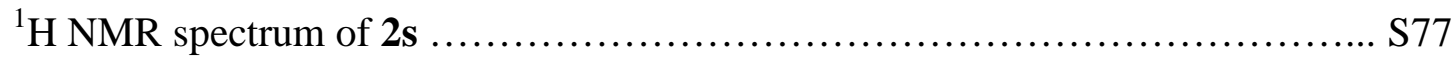

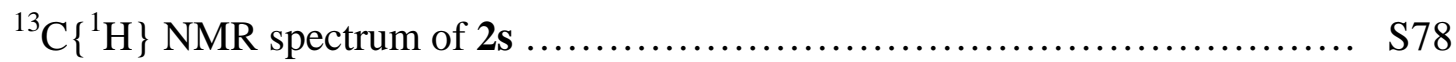

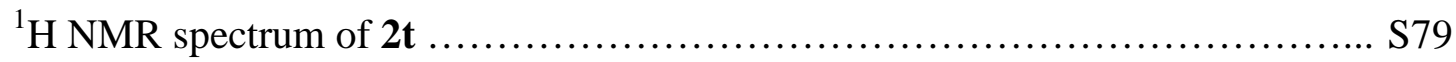

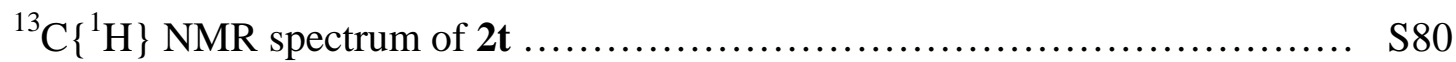

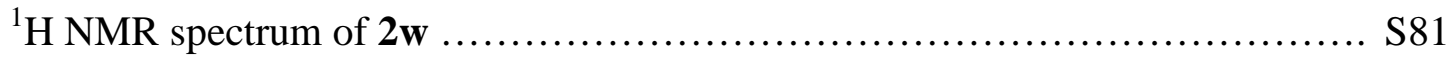

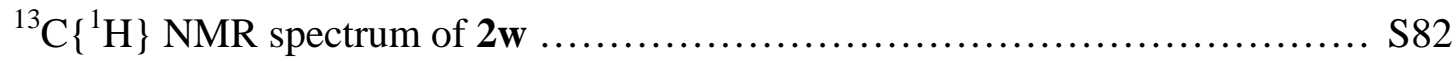

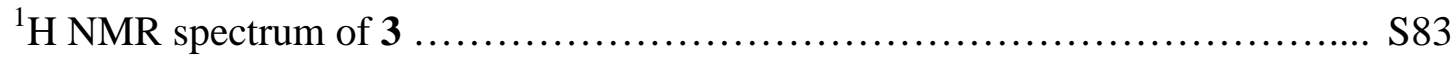

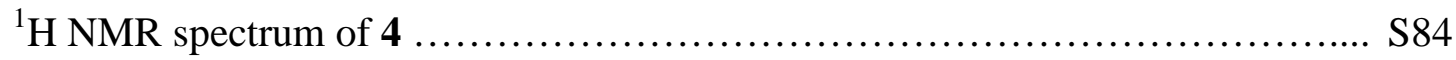

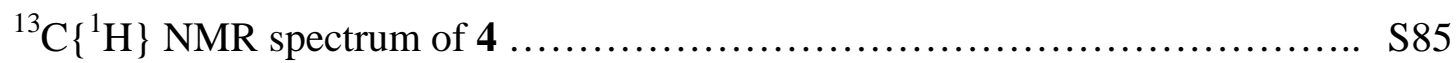

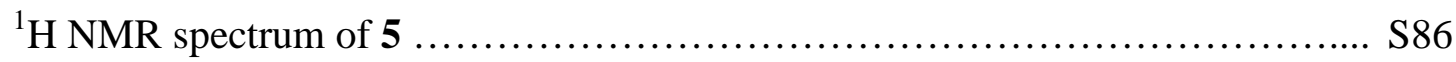

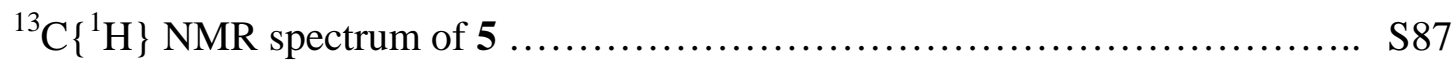

${ }^{1} \mathrm{H}$ NMR spectrum of Meisenheimer intermediate ......................... S88

${ }^{13} \mathrm{C}\left\{{ }^{1} \mathrm{H}\right\}$ NMR spectrum of Meisenheimer intermediate ..................... S89 
${ }^{1} \mathrm{H}$ NMR spectrum of $1 \mathrm{a}$ in $\mathrm{CDCl}_{3}$ with $0.05 \% \mathrm{v} / \mathrm{v}$ TMS $(400 \mathrm{MHz})$

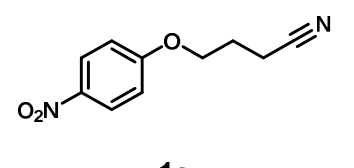

$1 a$
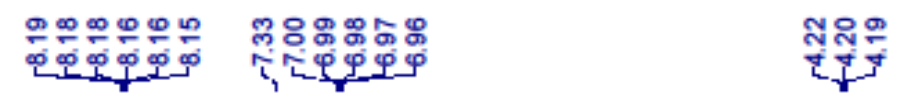

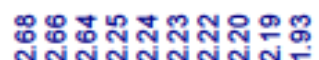

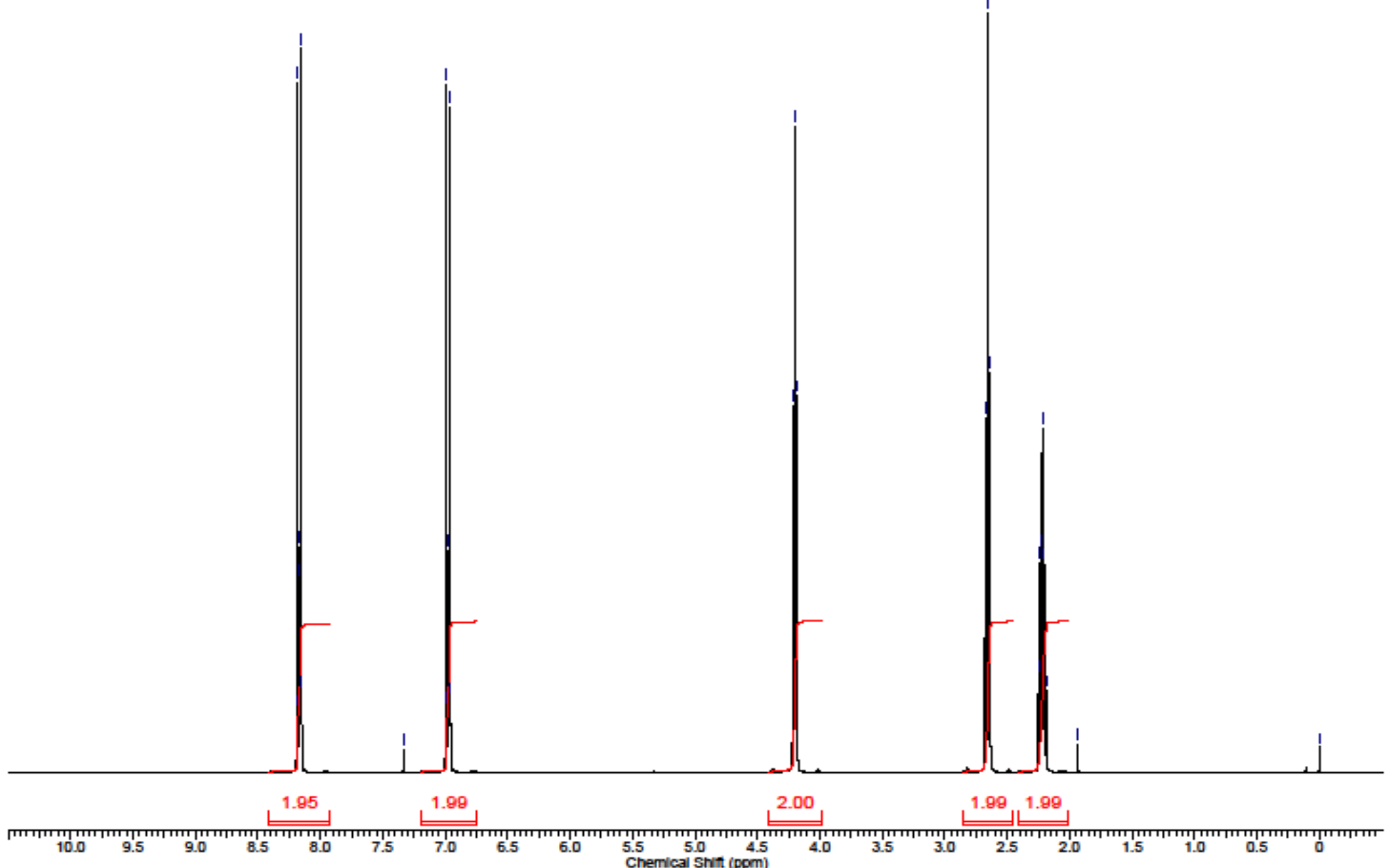


${ }^{1} \mathrm{H}$ NMR spectrum of 1a in $\left(\mathrm{CD}_{3}\right)_{2}$ SO with $0.05 \% \mathrm{v} / \mathrm{v}$ TMS $(400 \mathrm{MHz})$

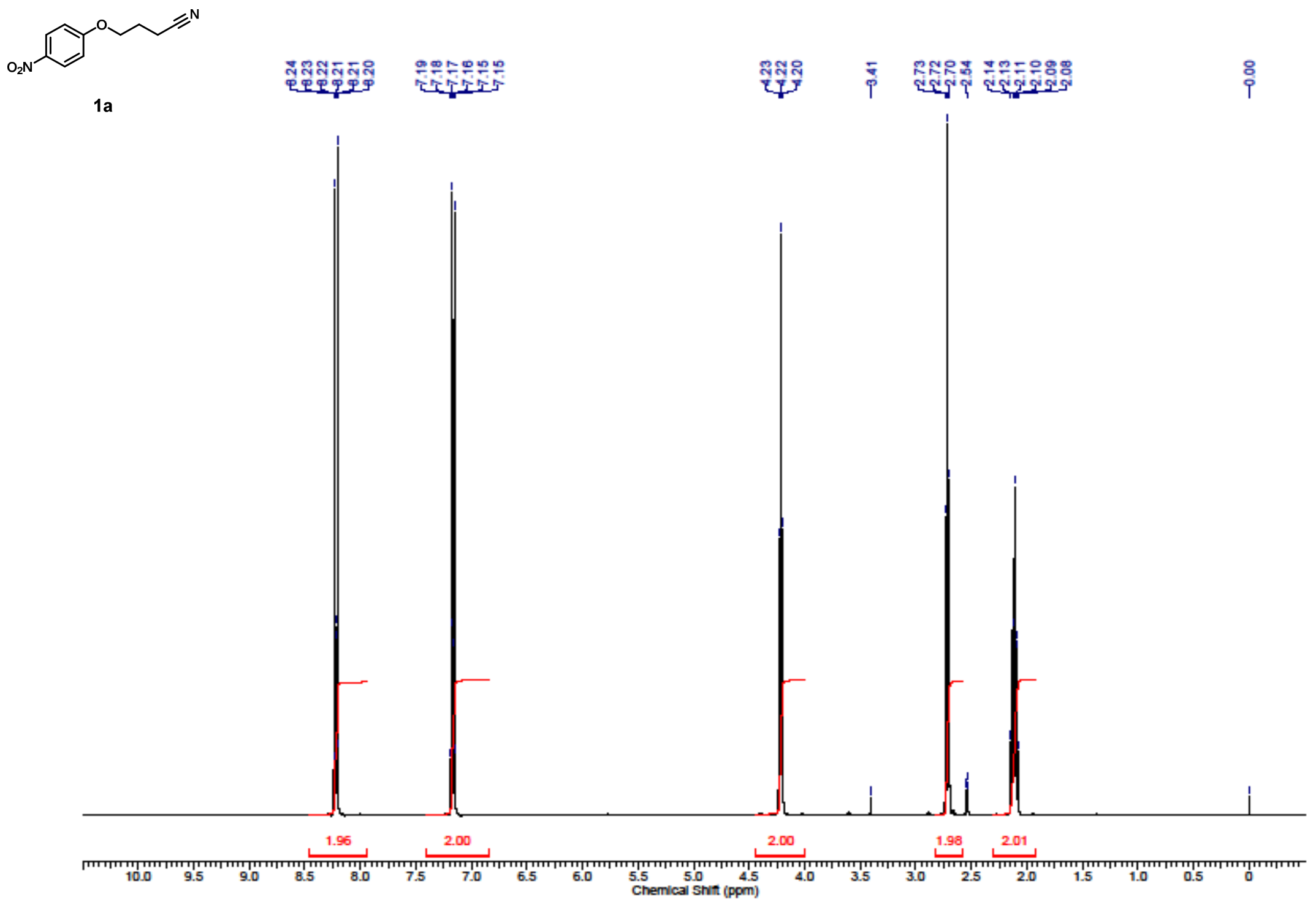


${ }^{13} \mathrm{C}\left\{{ }^{1} \mathrm{H}\right\}$ NMR spectrum of $\mathbf{1 a}$ in $\mathrm{CDCl}_{3}$ with $0.05 \% \mathrm{v} / \mathrm{v}$ TMS (100 MHz)<smiles>N#CCCCOc1ccc([N+](=O)[O-])cc1</smiles>

$1 \mathrm{a}$

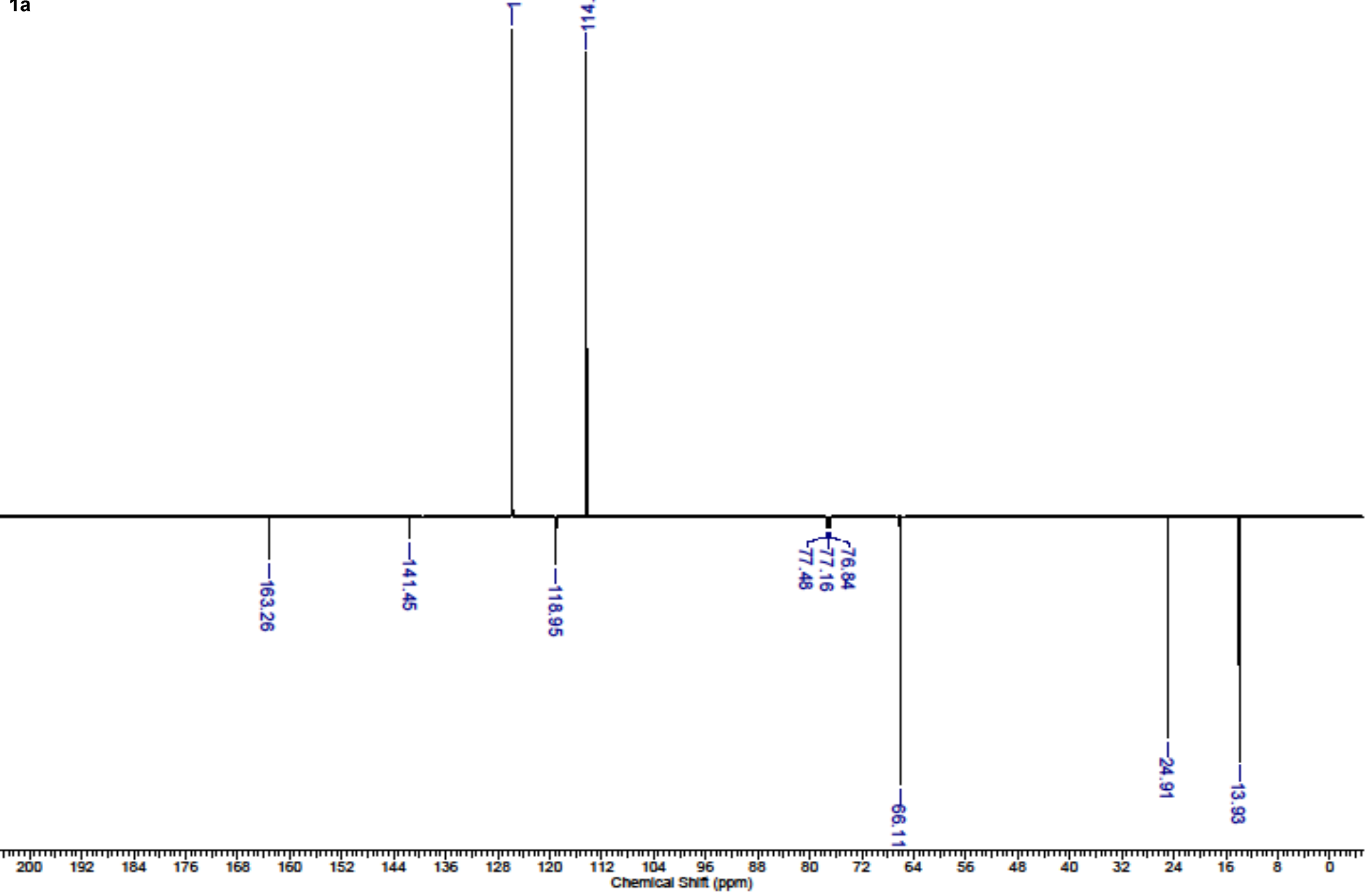


${ }^{13} \mathrm{C}\left\{{ }^{1} \mathrm{H}\right\}$ NMR spectrum of $1 \mathrm{a}$ in $\left(\mathrm{CD}_{3}\right)_{2} \underline{S O}$ with $0.05 \% \mathrm{v} / \mathrm{v}$ TMS $(100 \mathrm{MHz})$

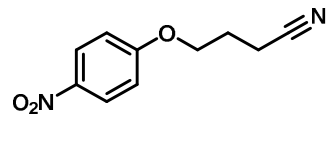

$1 \mathrm{a}$

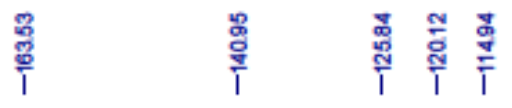

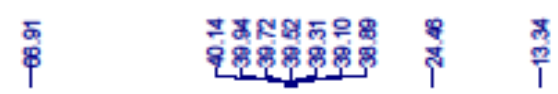

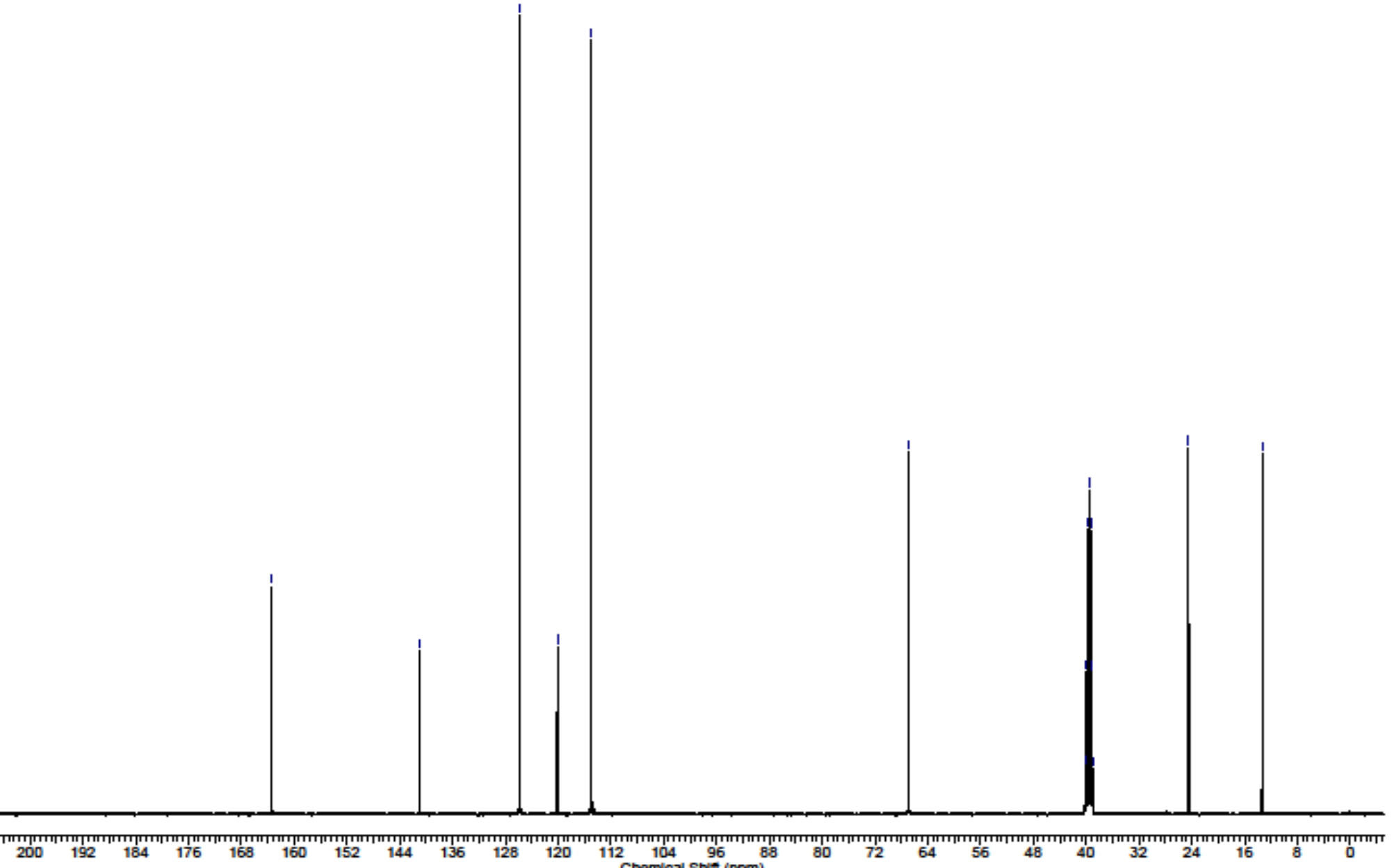


${ }^{1} \mathrm{H}$ NMR spectrum of $\mathbf{1 b}$ in $\mathrm{CDCl}_{3}$ with $0.05 \% \mathrm{v} / \mathrm{v}$ TMS (400 MHz)

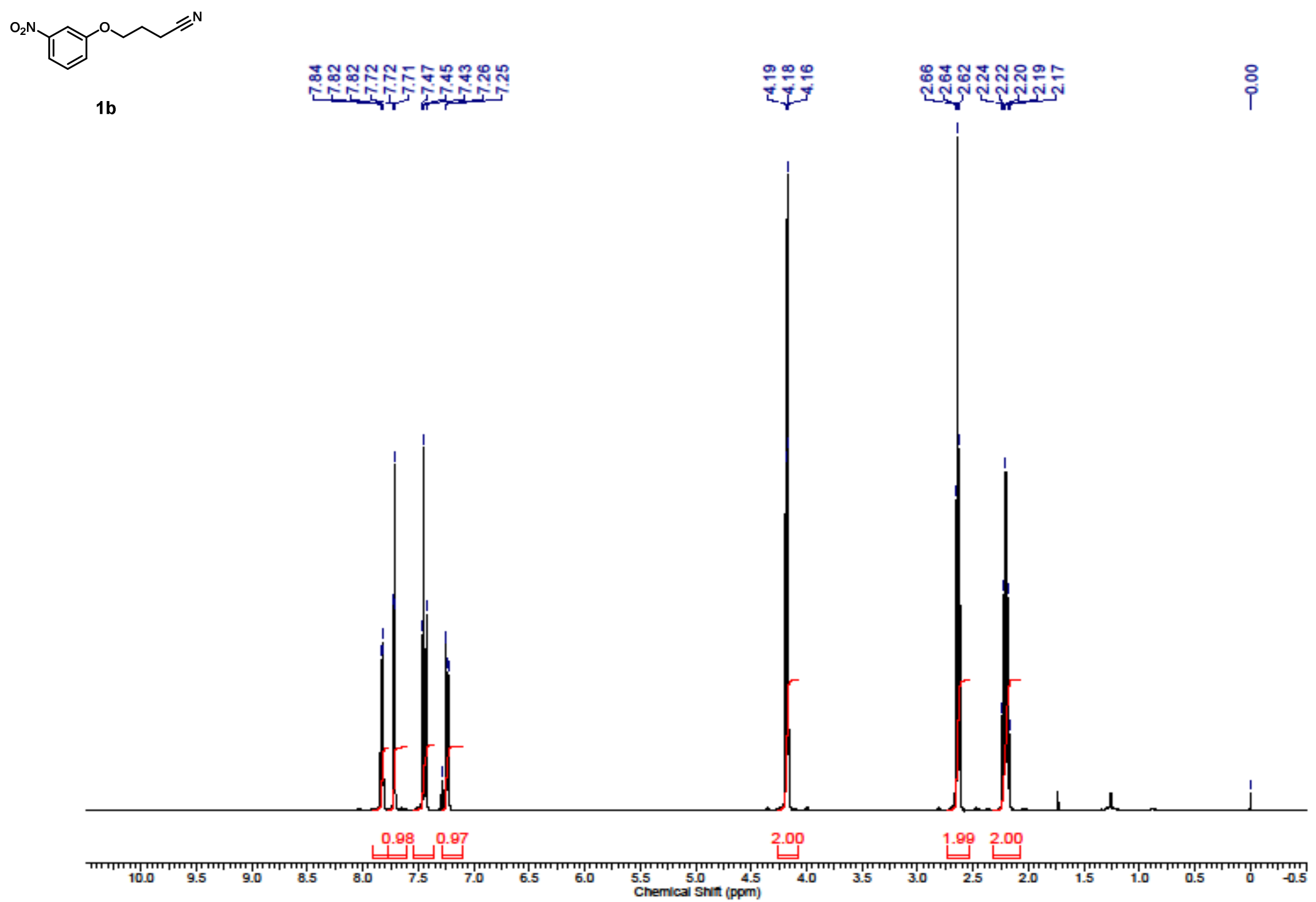


${ }^{13} \mathrm{C}\left\{{ }^{1} \mathrm{H}\right\}$ NMR spectrum of $\mathbf{1 b}$ in $\mathrm{CDCl}_{3}$ with $0.05 \% \mathrm{v} / \mathrm{v}$ MS $(100 \mathrm{MHz})$

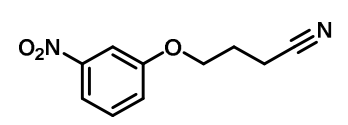

$1 \mathrm{~b}$
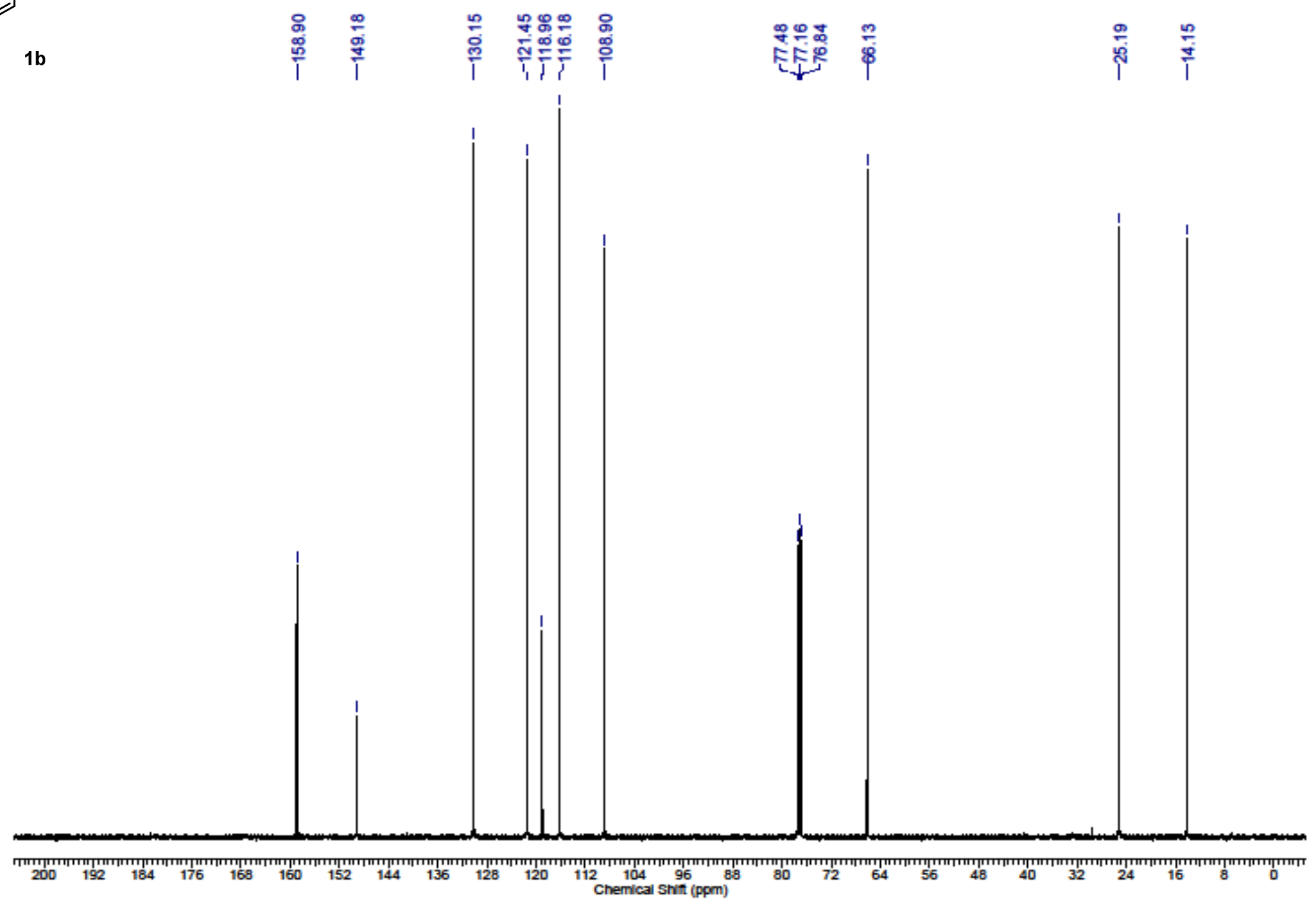

S10 
${ }^{1} \mathrm{H}$ NMR spectrum of $1 \mathrm{c}$ in $\mathrm{CDCl}_{3}$ with $0.05 \% \mathrm{v} / \mathrm{v}$ TMS $(400 \mathrm{MHz})$

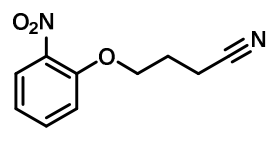

$1 c$

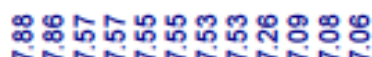

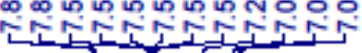

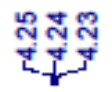

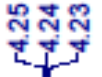

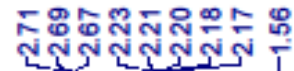

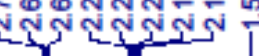

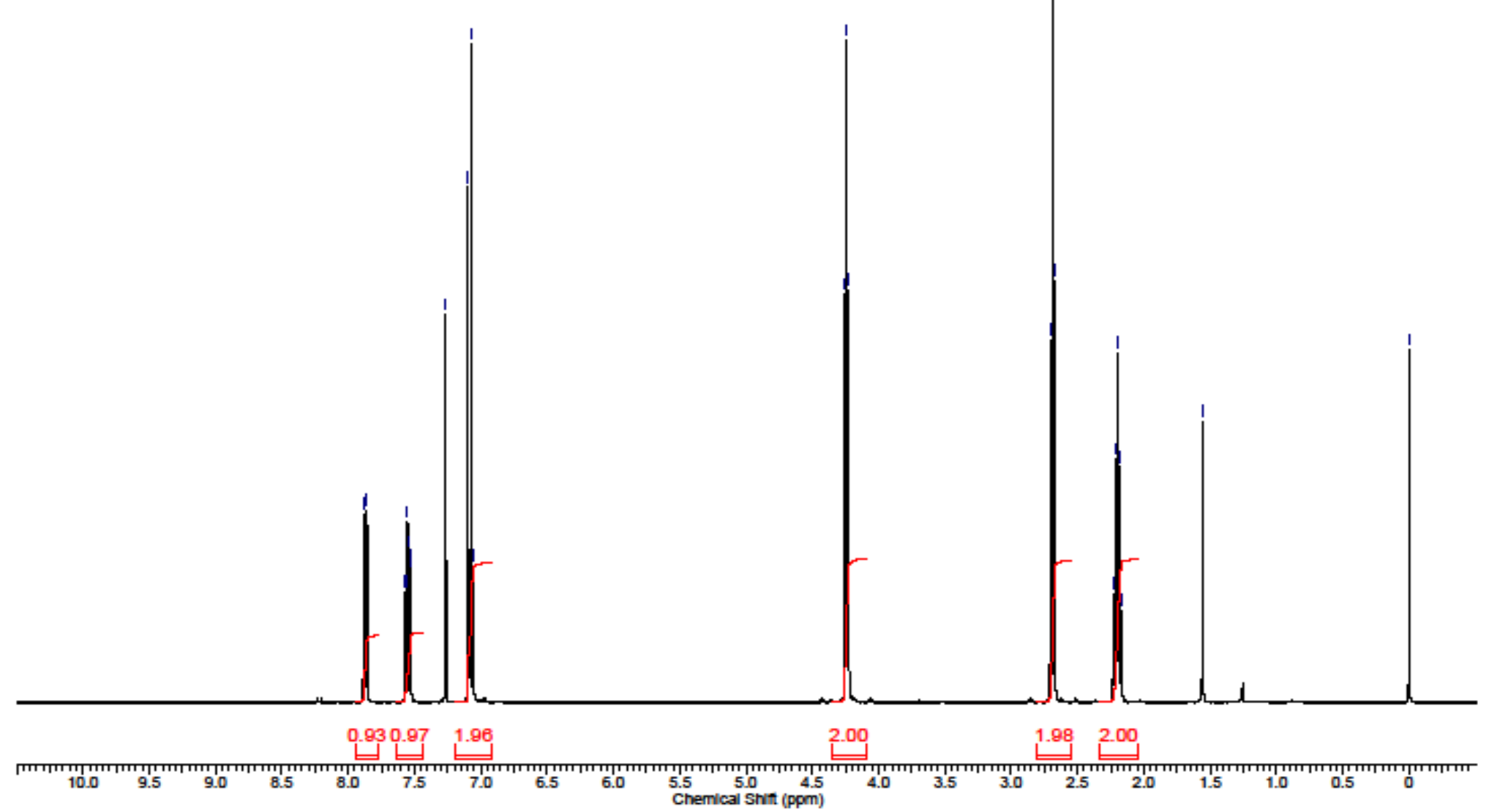


${ }^{13} \mathrm{C}\left\{{ }^{1} \mathrm{H}\right\}$ NMR spectrum of $1 \mathrm{c}$ in $\mathrm{CDCl}_{3}$ with $0.05 \% \mathrm{v} / \mathrm{v}$ TMS $(100 \mathrm{MHz})$

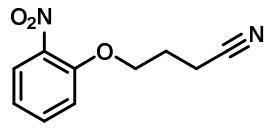

1c

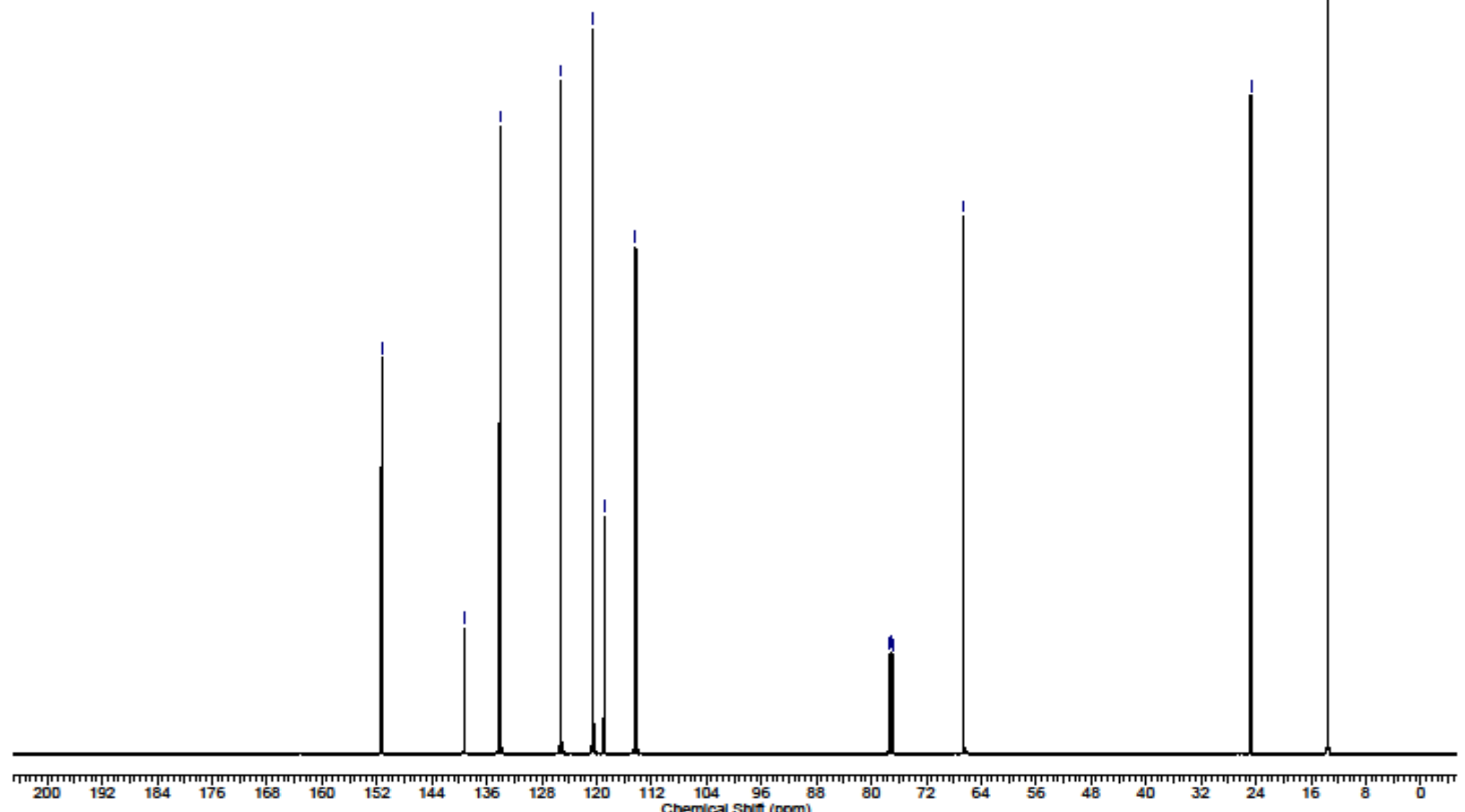


${ }^{1} \mathrm{H}$ NMR spectrum of $\mathbf{1 d}$ in $\mathrm{CDCl}_{3}$ with $0.05 \% \mathrm{v} / \mathrm{v}$ TMS $(400 \mathrm{MHz})$
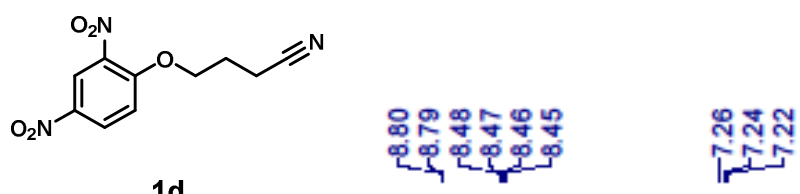

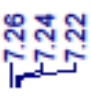

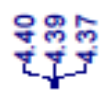

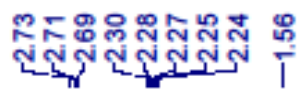

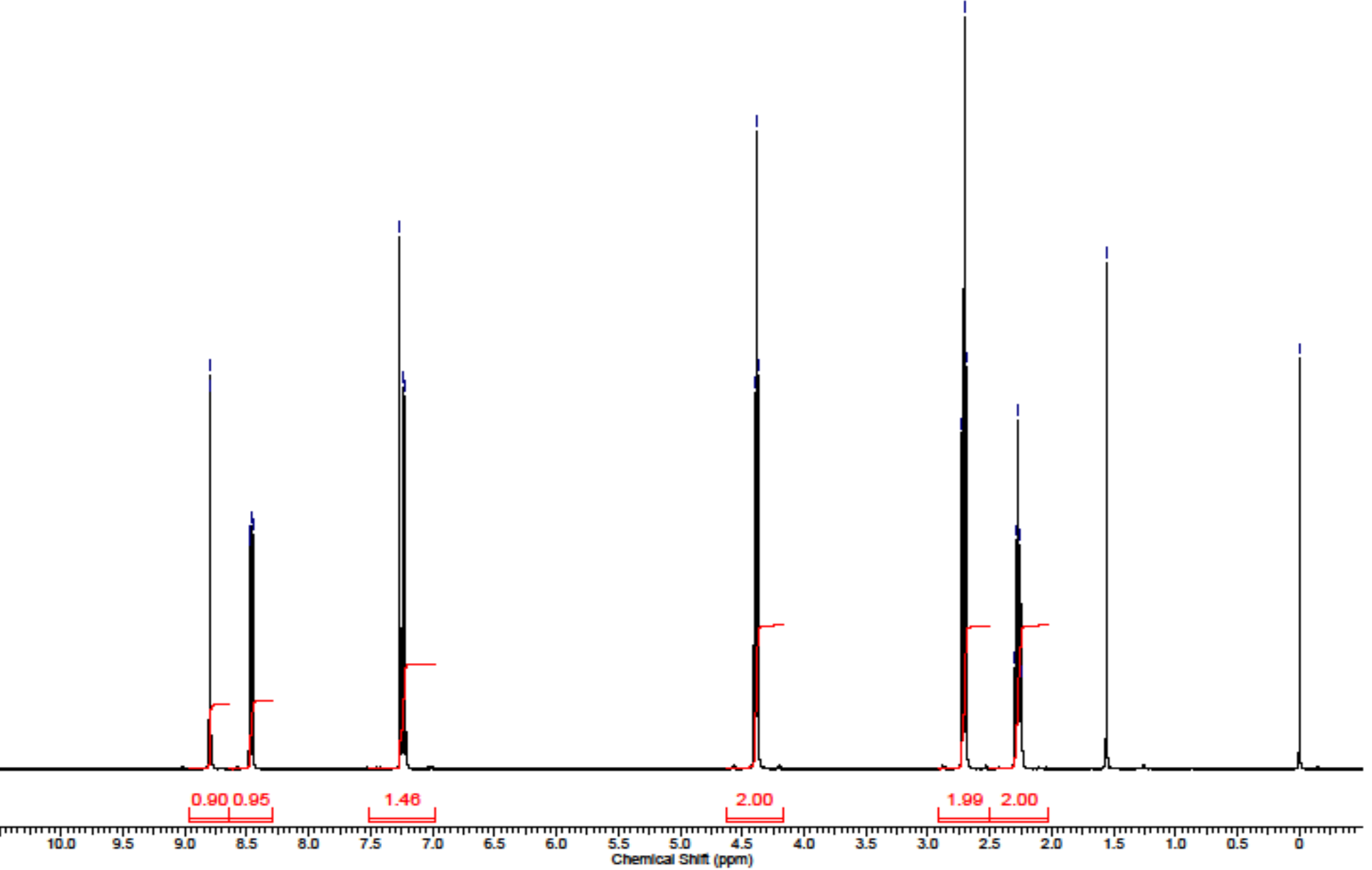


${ }^{13} \mathrm{C}\left\{{ }^{1} \mathrm{H}\right\}$ NMR spectrum of $\mathbf{1 d}$ in $\mathrm{CDCl}_{3}$ with $0.05 \% \mathrm{v} / \mathrm{v}$ TMS (100 MHz)

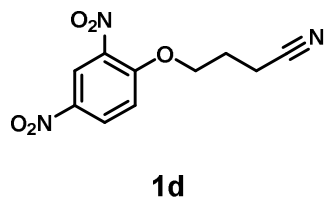

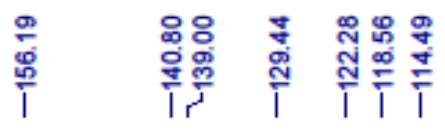

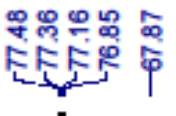

एक

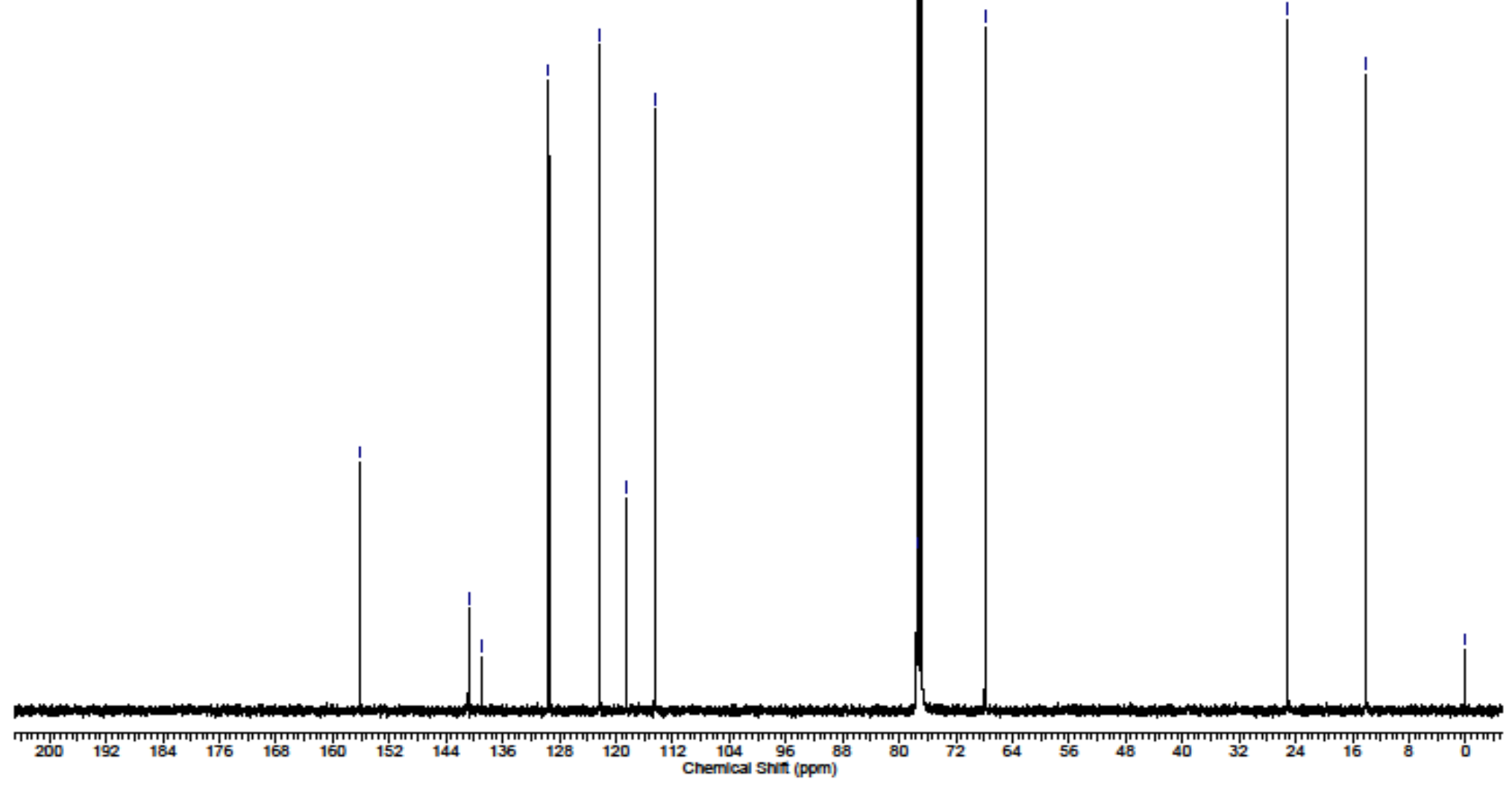


${ }^{1} \mathrm{H}$ NMR spectrum of $1 \mathrm{e}$ in $\mathrm{CDCl}_{3}$ with $0.05 \% \mathrm{v} / \mathrm{v}$ TMS (400 MHz)
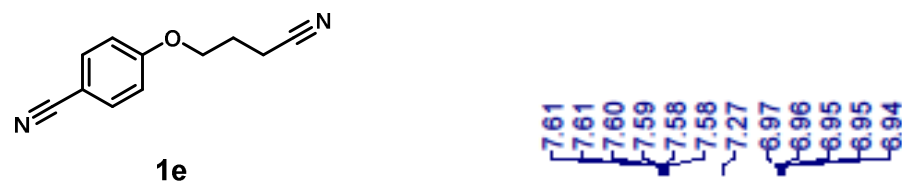

$\frac{\pi}{4} \frac{m}{i}$

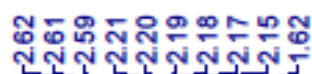

i

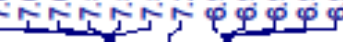

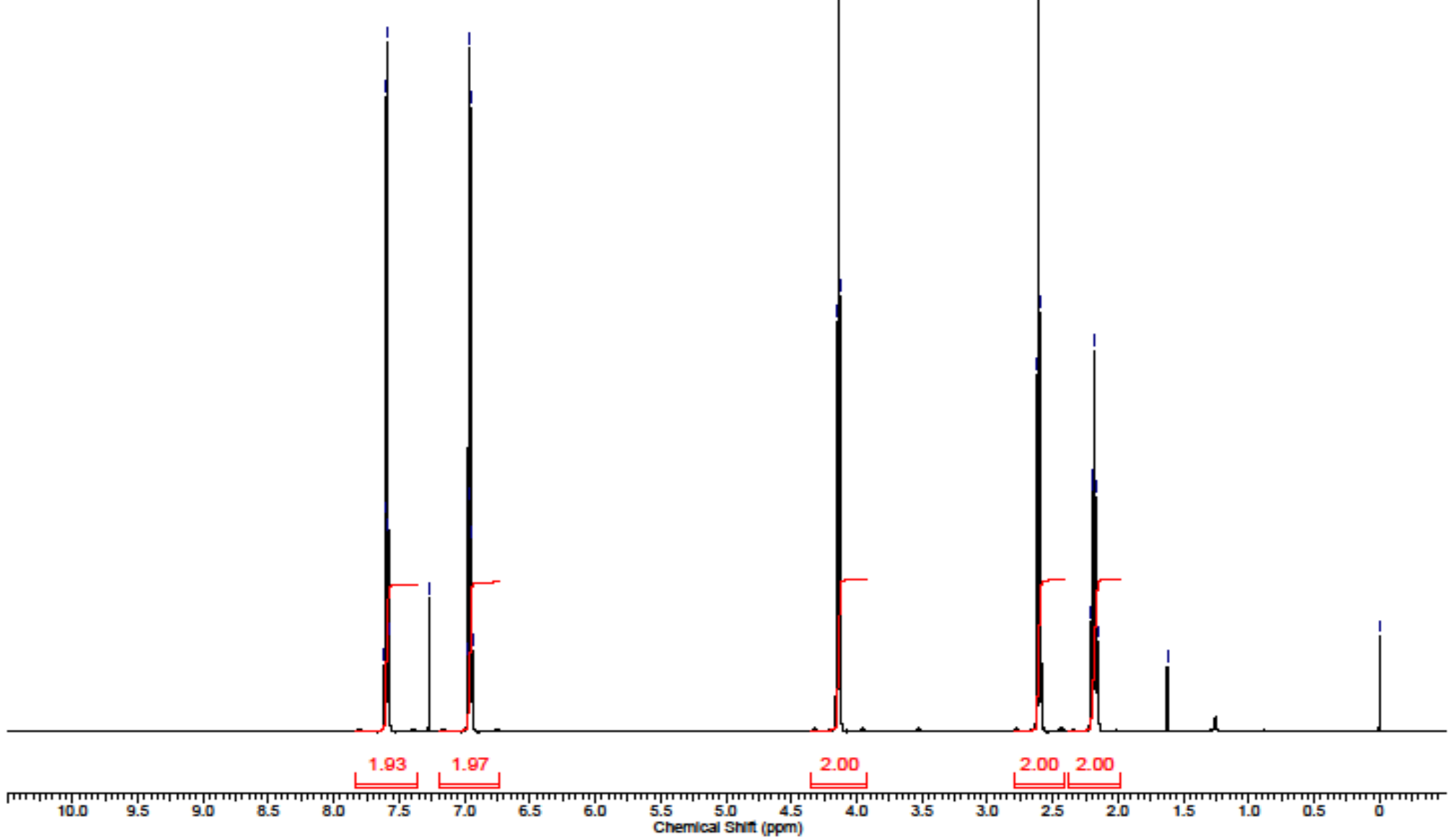


${ }^{13} \mathrm{C}\left\{{ }^{1} \mathrm{H}\right\}$ NMR spectrum of $1 \mathrm{e}$ in $\mathrm{CDCl}_{3}$ with $0.05 \% \mathrm{v} / \mathrm{v}$ TMS $(100 \mathrm{MHz})$

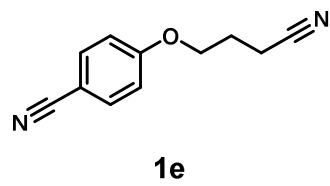

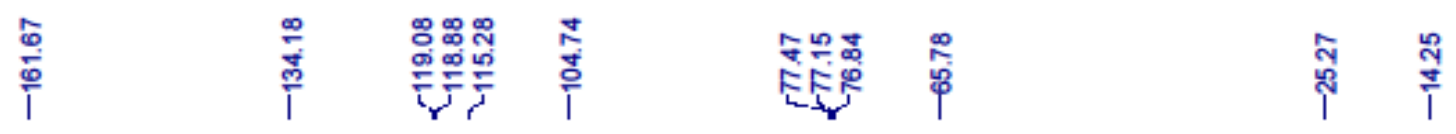

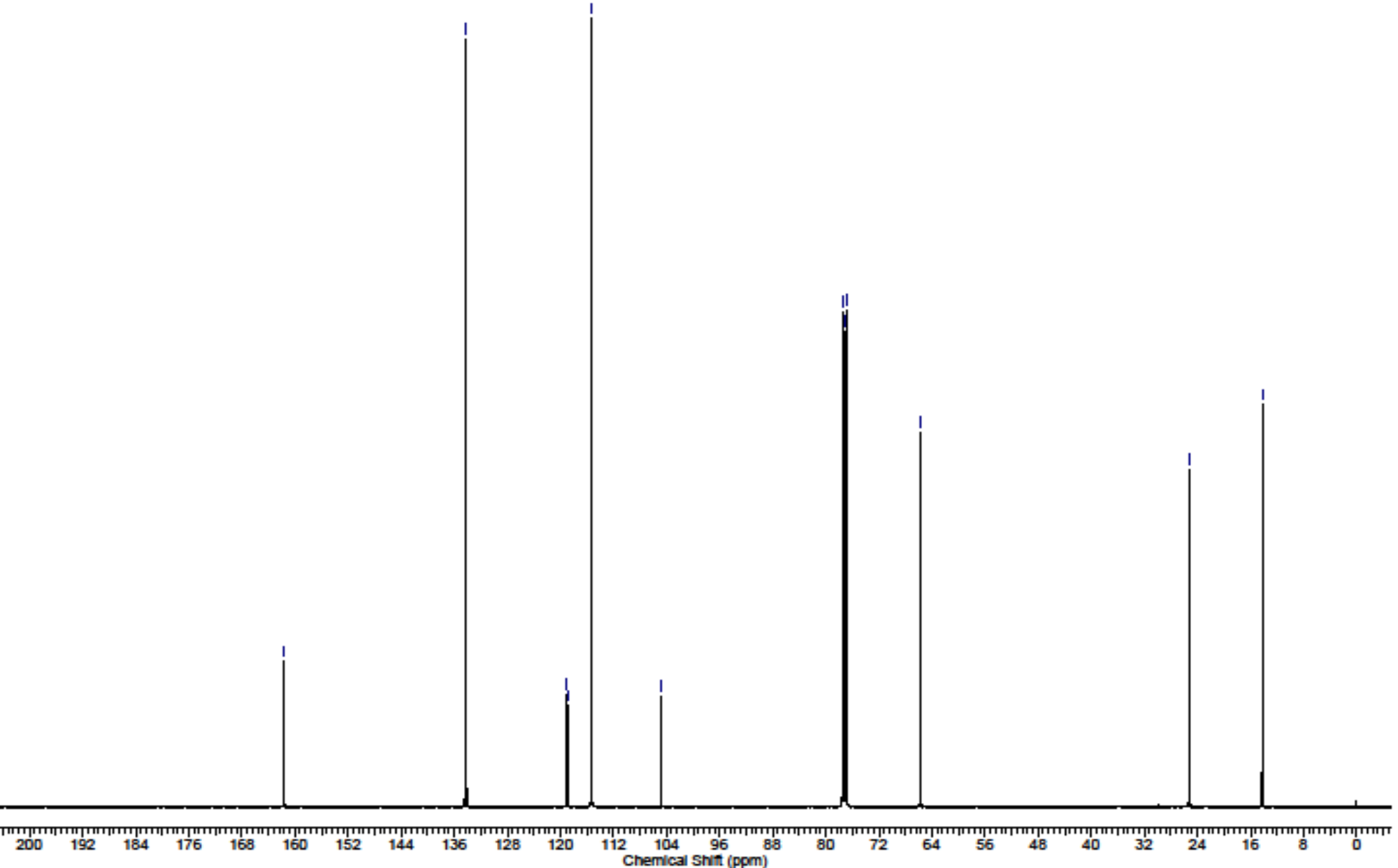


$\underline{{ }^{1} \mathrm{H} \text { NMR spectrum of } \mathbf{1 f} \text { in } \mathrm{CDCl}_{3} \text { with } 0.05 \% \mathrm{v} / \mathrm{v} \text { TMS (400 MHz) }}$

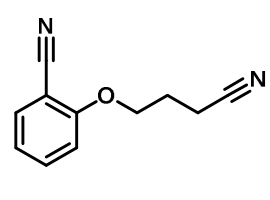

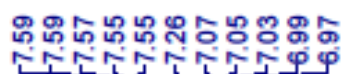

$1 f$
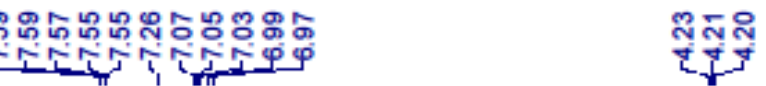

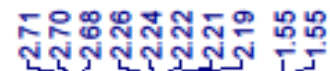
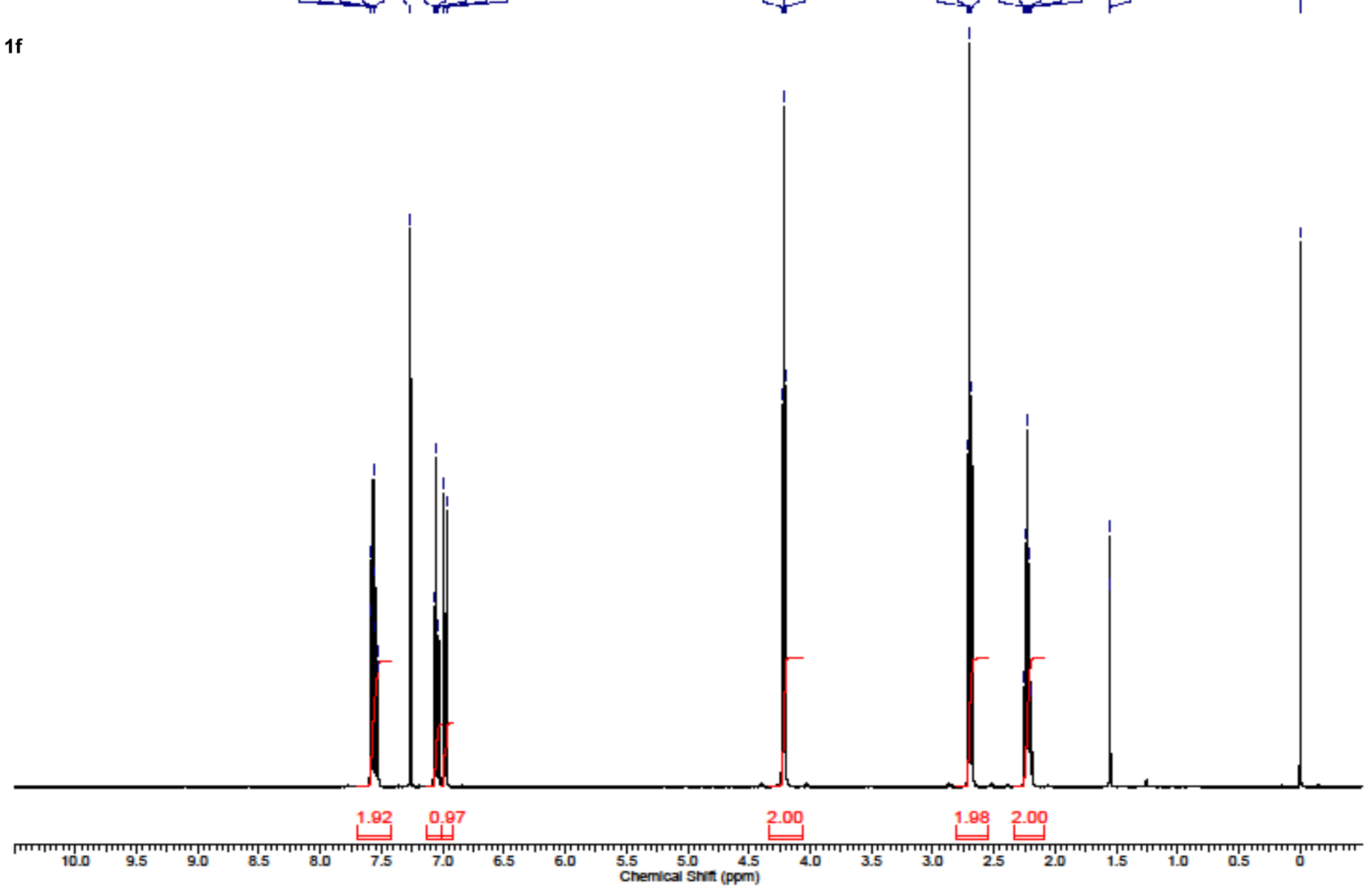
${ }^{13} \mathrm{C}\left\{{ }^{1} \mathrm{H}\right\}$ NMR spectrum of $\mathbf{1 f}$ in $\mathrm{CDCl}_{3}$ with $0.05 \% \mathrm{v} / \mathrm{v}$ TMS (100 MHz)

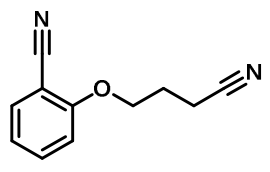

$1 f$

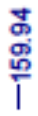

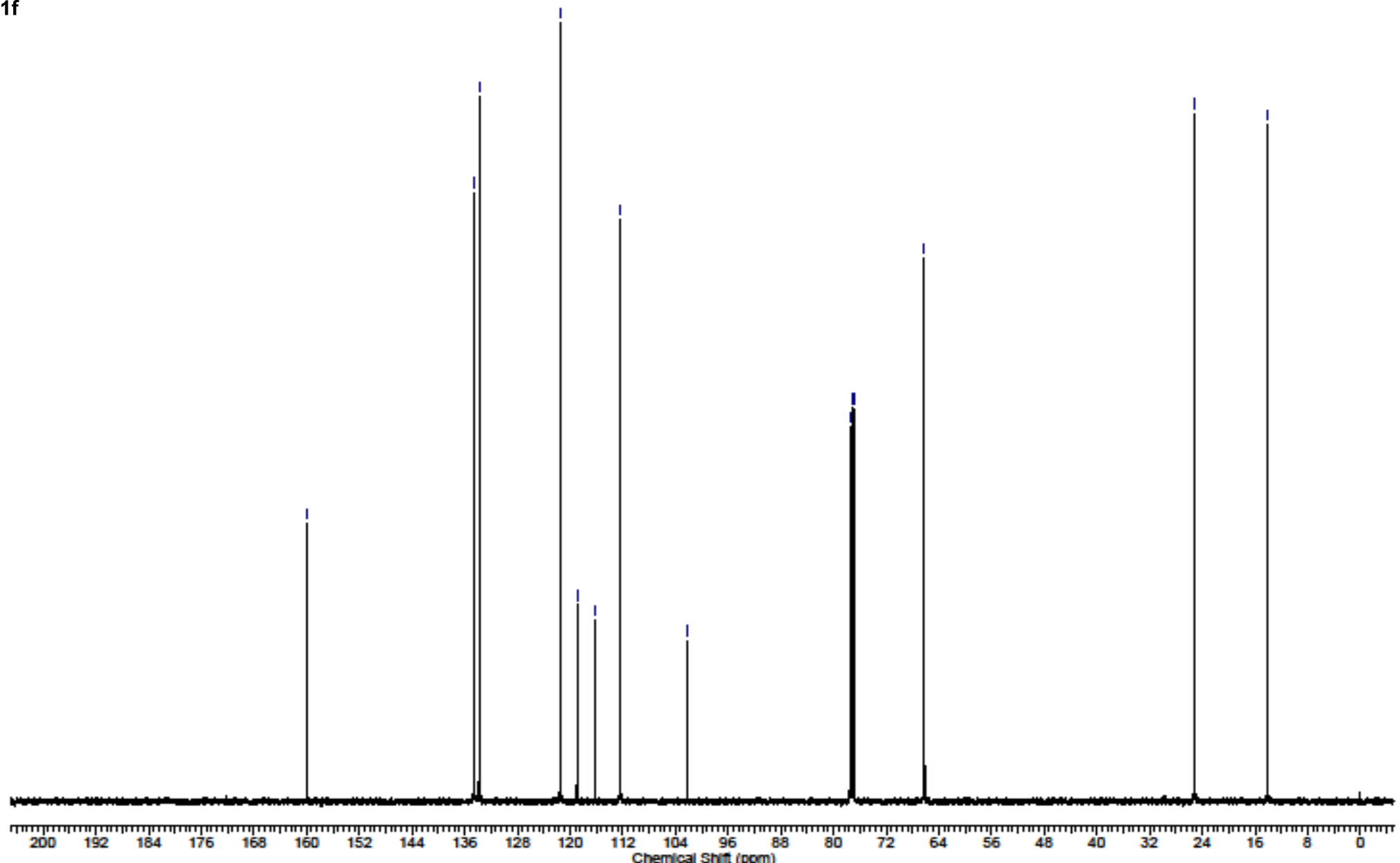

สู่

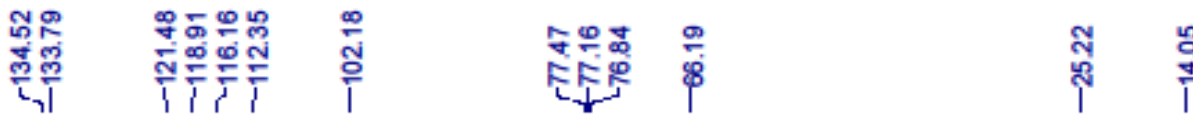

Chemical Sritt (ppm) 
${ }^{1} \mathrm{H}$ NMR spectrum of $1 \mathrm{~g}$ in $\mathrm{CDCl}_{3}$ with $0.05 \% \mathrm{v} / \mathrm{v}$ TMS $(400 \mathrm{MHz})$

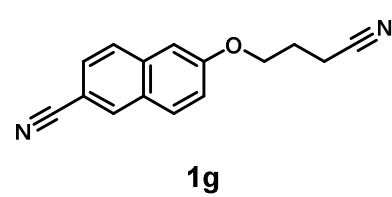

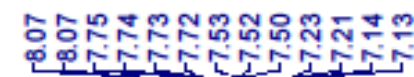
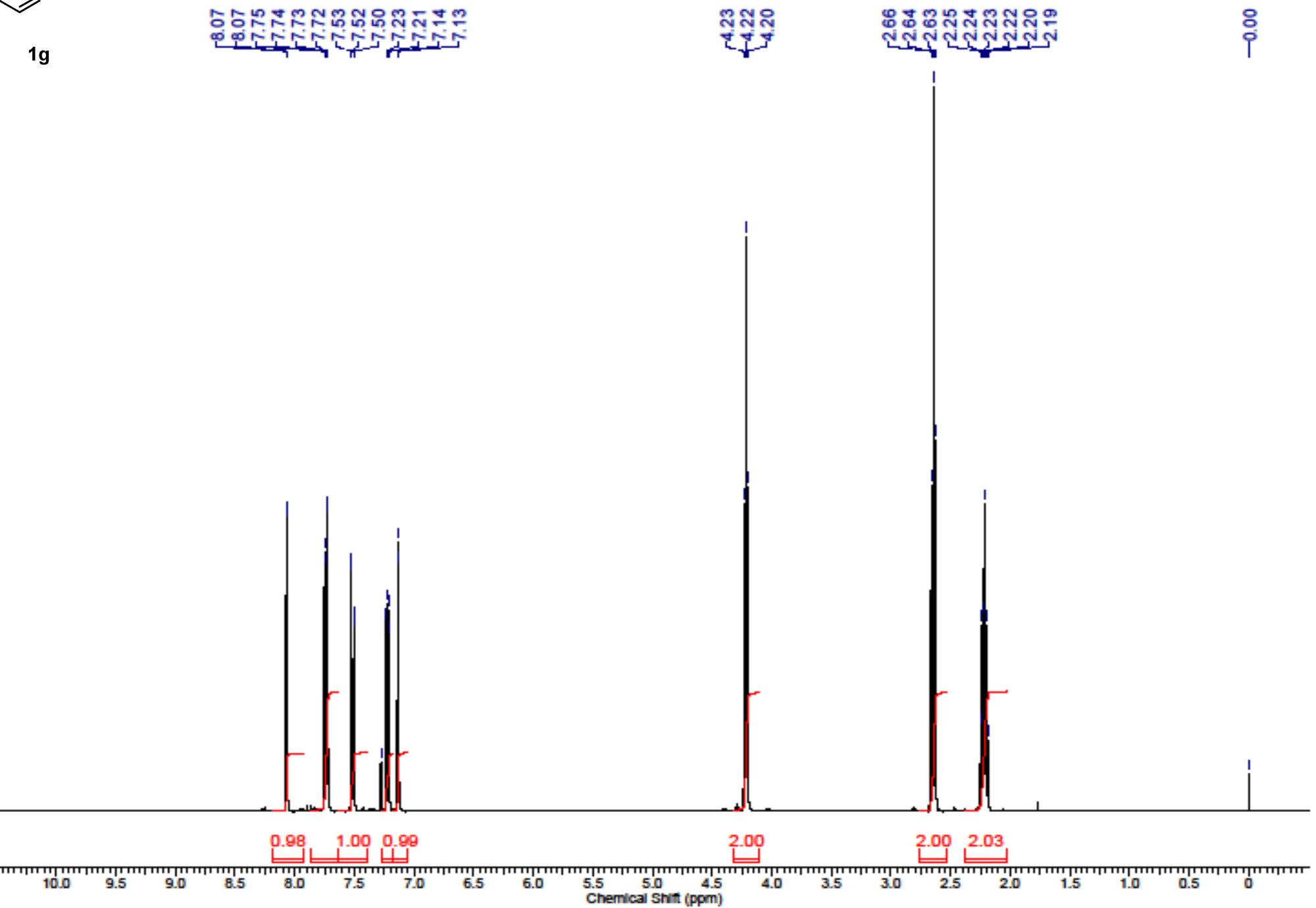
${ }^{13} \mathrm{C}\left\{{ }^{1} \mathrm{H}\right\}$ NMR spectrum of $\mathbf{1 g}$ in $\mathrm{CDCl}_{3}$ with $0.05 \% \mathrm{v} / \mathrm{v}$ TMS (100 MHz)
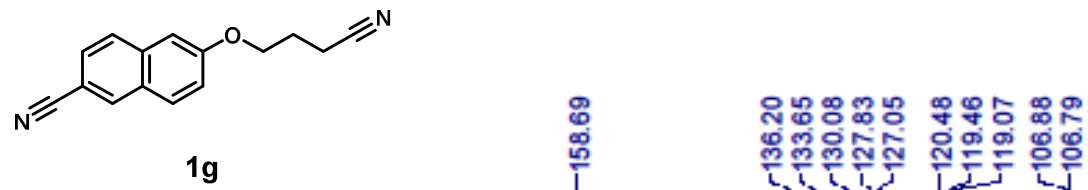

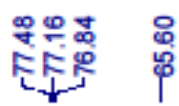

สู้ สุ

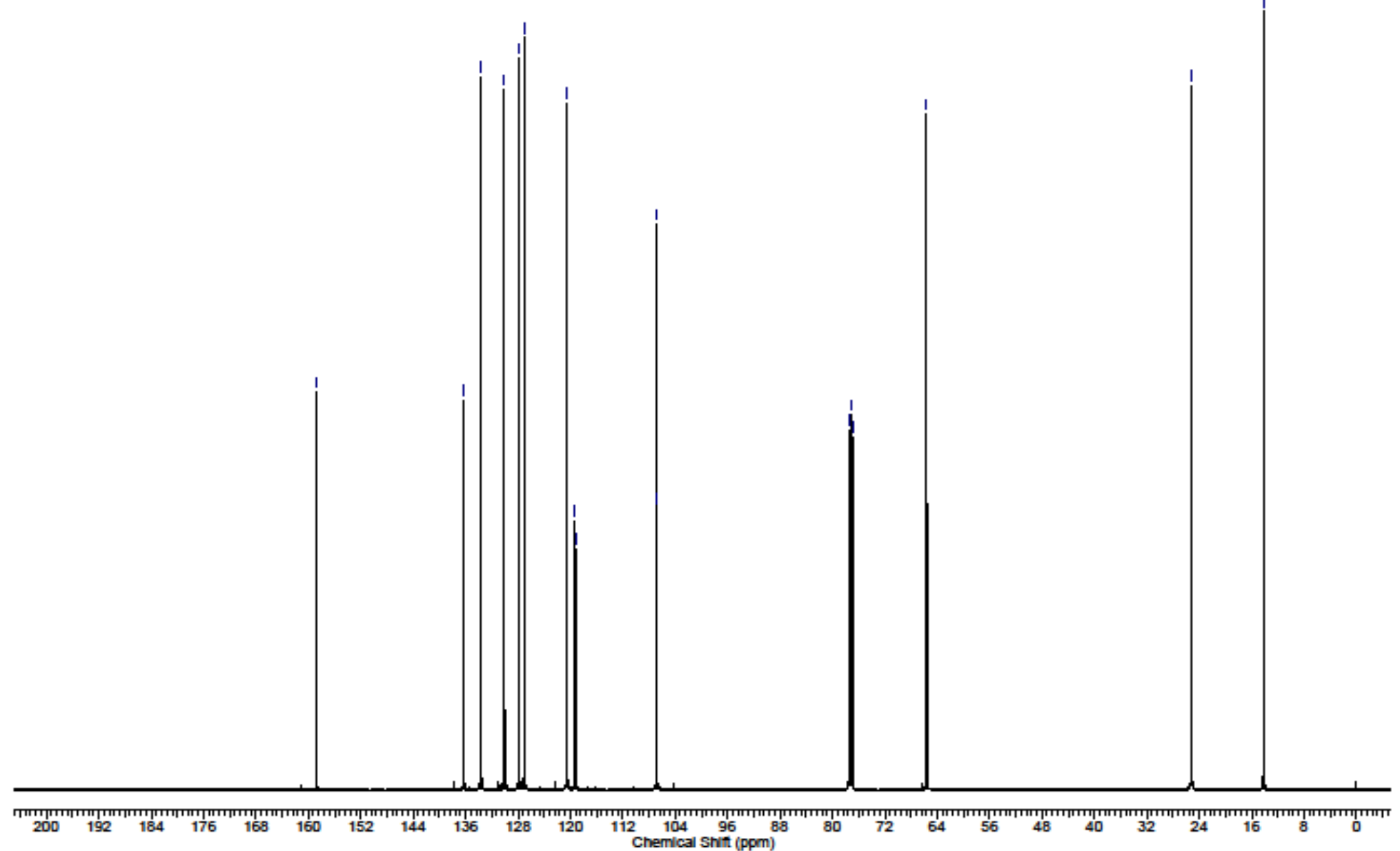


${ }^{1} \mathrm{H}$ NMR spectrum of $\mathbf{1 h}$ in $\mathrm{CDCl}_{3}$ with $0.05 \% \mathrm{v} / \mathrm{v}$ TMS (400 MHz)
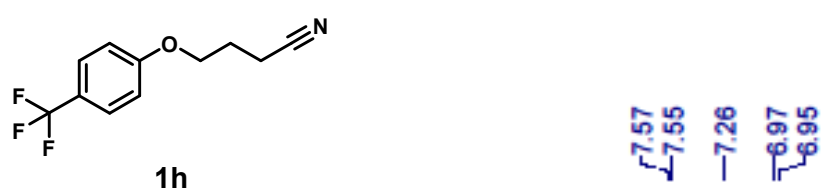

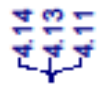

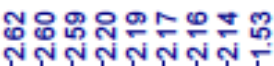
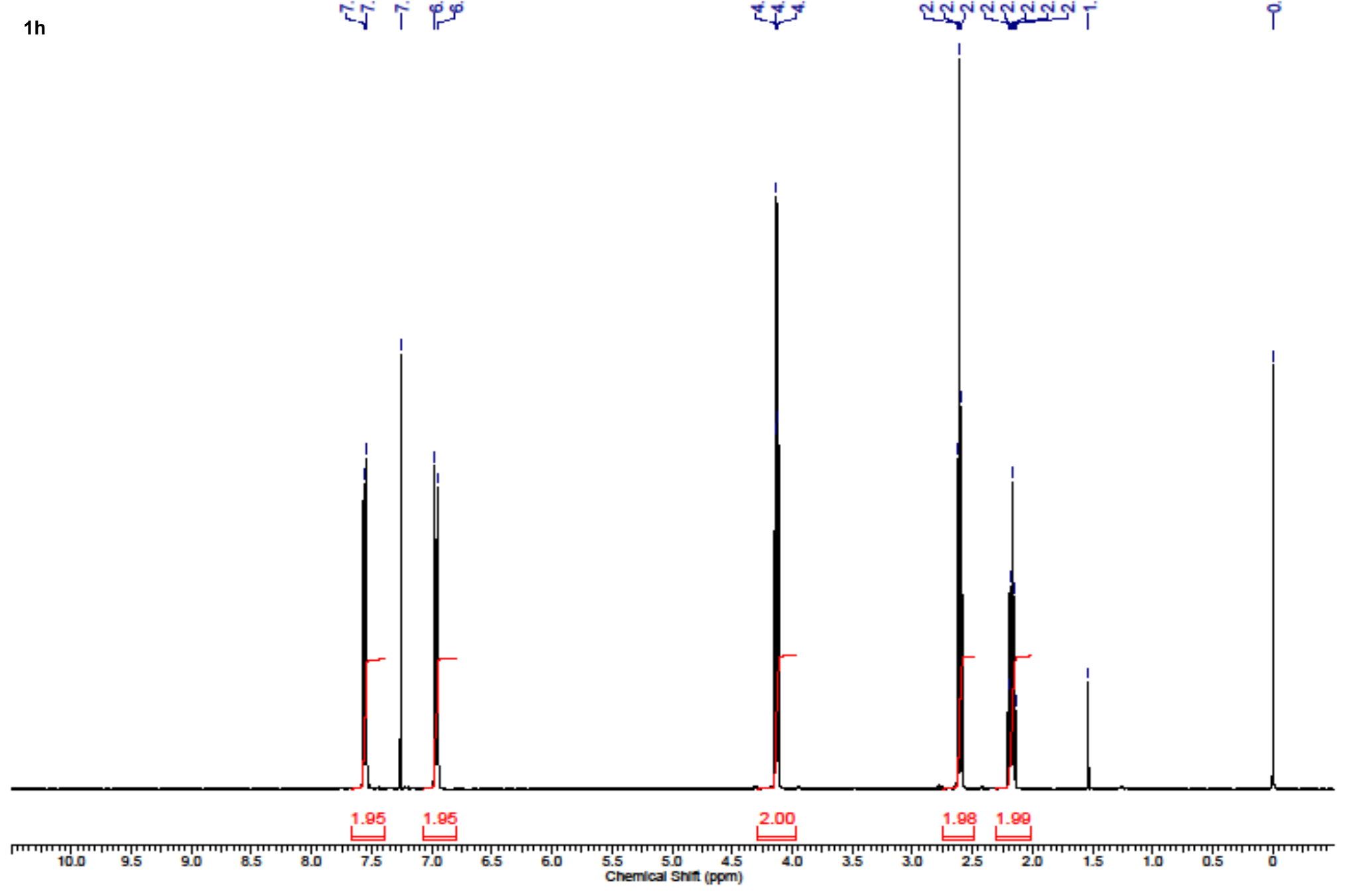
$\left.{ }^{13} \mathrm{C}^{1}{ }^{1} \mathrm{H}\right\}$ NMR spectrum of $\mathbf{1 h}$ in $\mathrm{CDCl}_{3}$ with $0.05 \%$ v/v TMS (100 MHz)

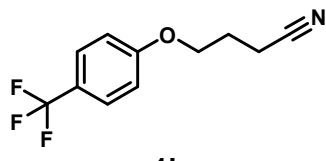

$1 \mathrm{~h}$

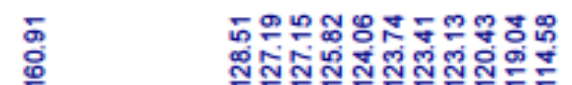

$\stackrel{\oplus}{\text { I }}$

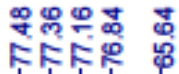

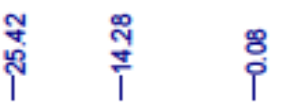


$\underline{{ }^{1} \mathrm{H} \text { NMR spectrum of } 1 \mathbf{i} \text { in } \mathrm{CDCl}_{3} \text { with } 0.05 \% \mathrm{v} / \mathrm{v} \text { TMS }(400 \mathrm{MHz})}$

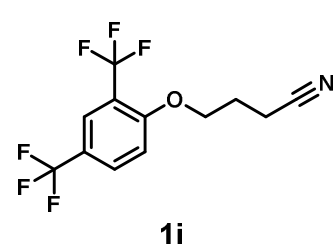

makR 우요

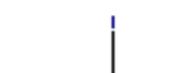

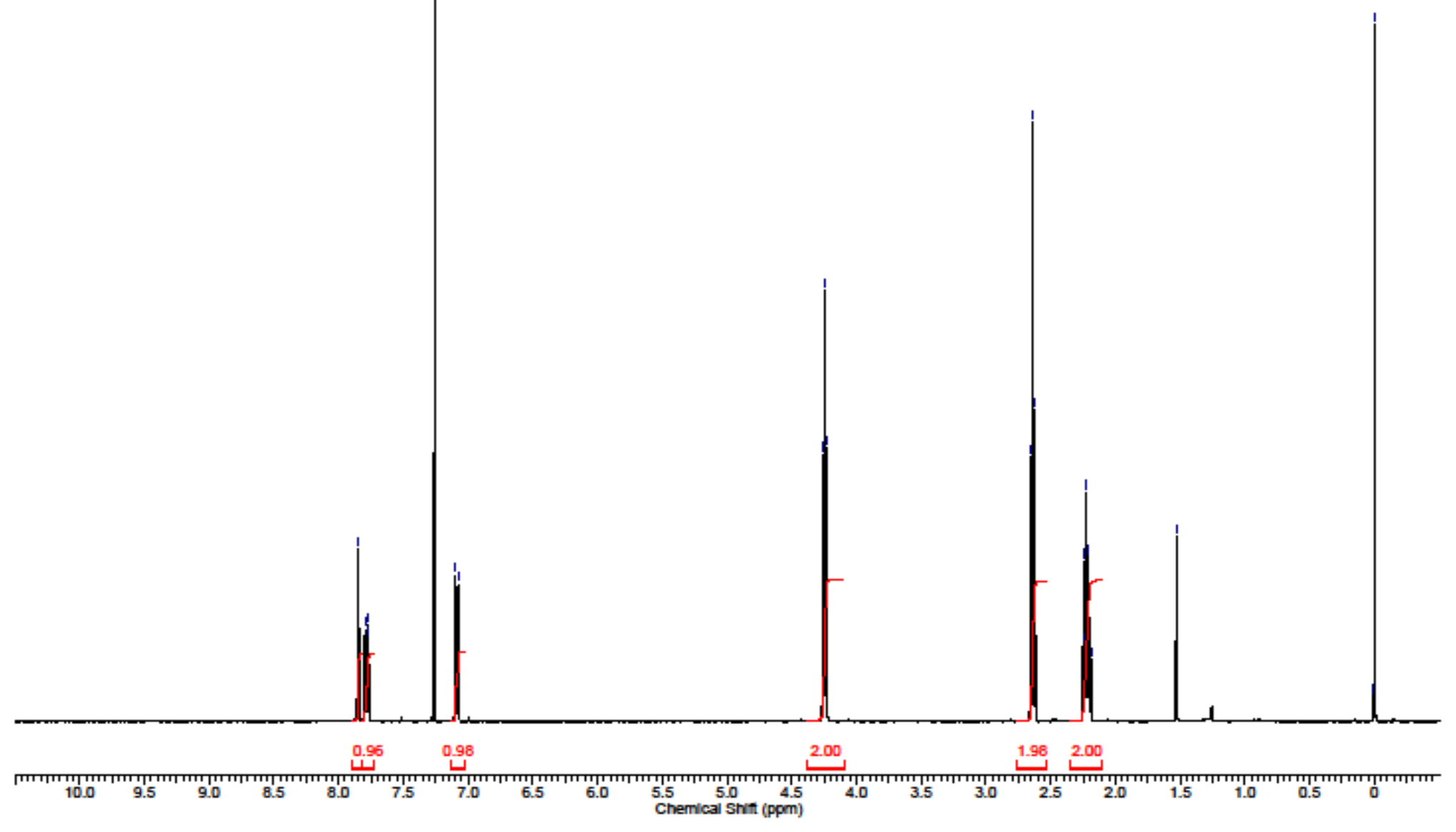


${ }^{13} \mathrm{C}\left\{{ }^{1} \mathrm{H}\right\}$ NMR spectrum of $1 \mathrm{i}$ in $\mathrm{CDCl}_{3}$ with $0.05 \% \mathrm{v} / \mathrm{v}$ TMS $(100 \mathrm{MHz})$
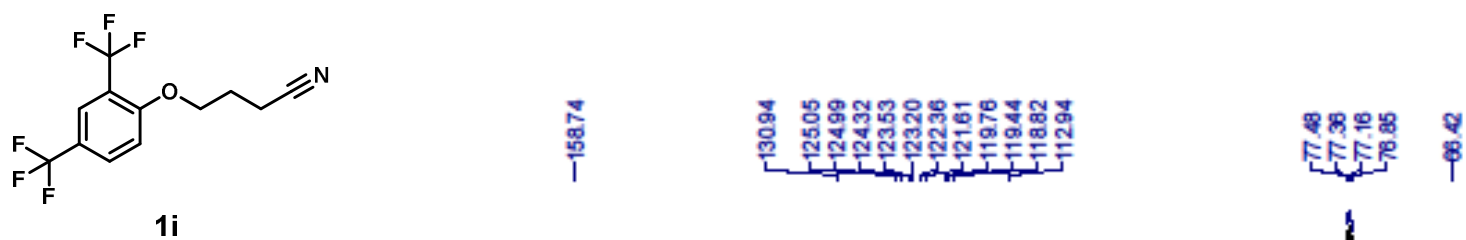

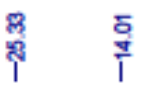

$1 i$

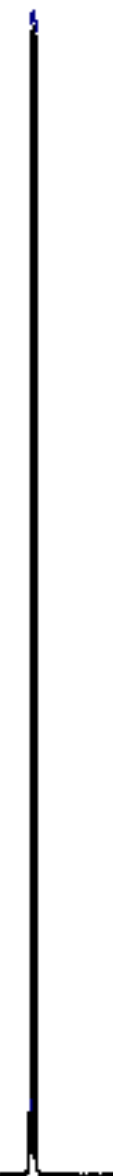

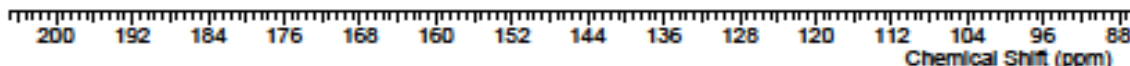


${ }^{1} \mathrm{H}$ NMR spectrum of $\mathbf{1} \mathbf{j}$ in $\mathrm{CDCl}_{3}$ with $0.05 \% \mathrm{v} / \mathrm{v}$ TMS $(400 \mathrm{MHz})$

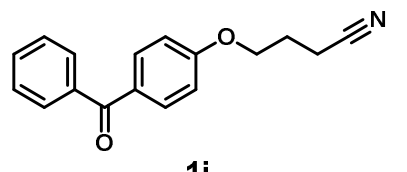

1j

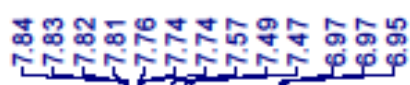

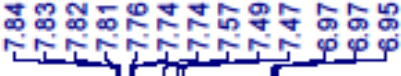

$2.97 \quad 1.98$

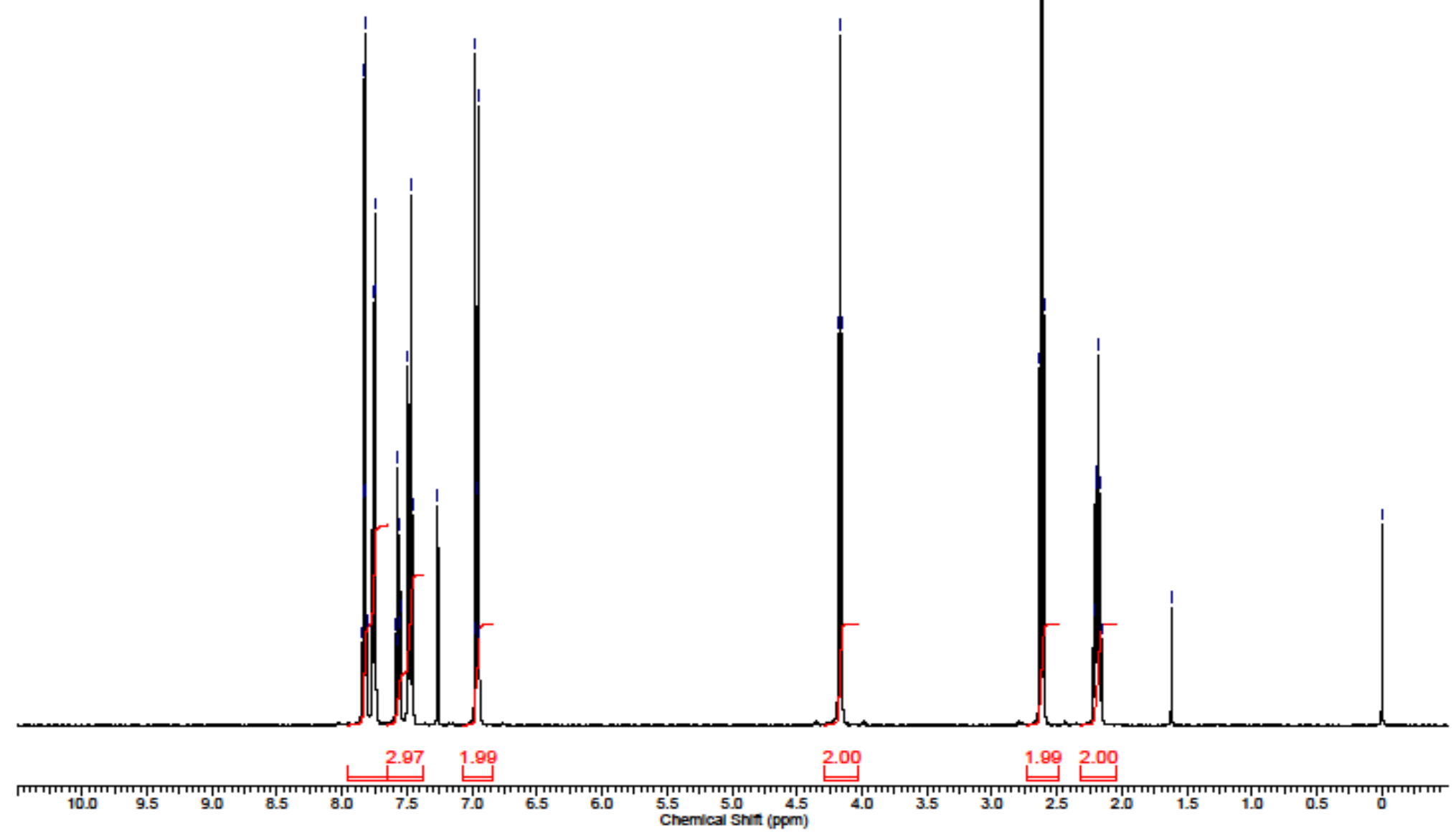

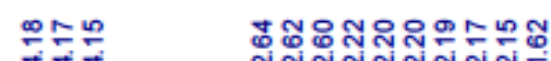

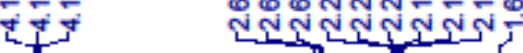

i 


$$
I_{1}
$$


${ }^{1} \mathrm{H}$ NMR spectrum of $\mathbf{1 k}$ in $\mathrm{CDCl}_{3}$ with $0.05 \% \mathrm{v} / \mathrm{v}$ TMS $(400 \mathrm{MHz})$

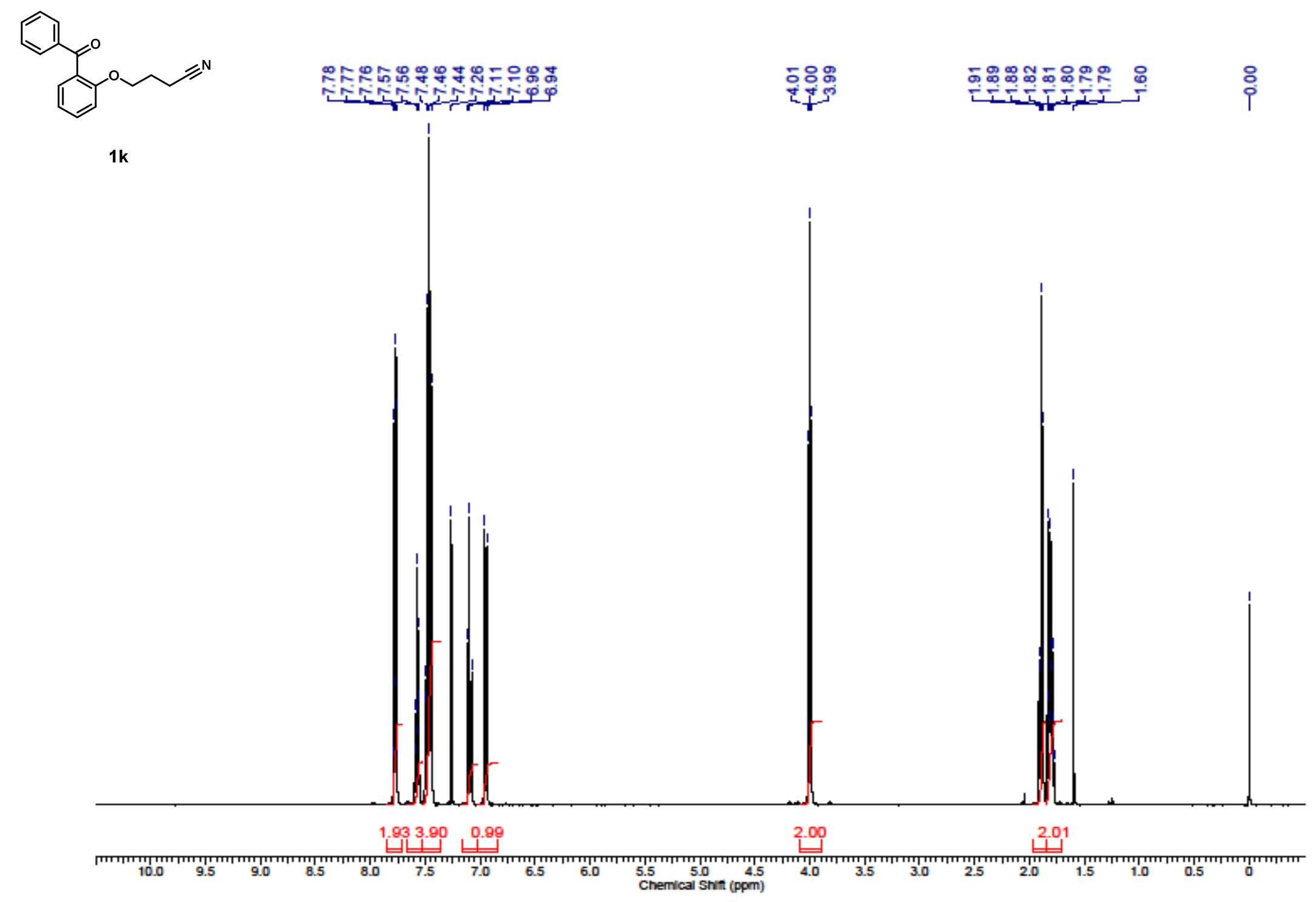


$\left.{ }^{13} \mathrm{C}_{\{}{ }^{1} \mathrm{H}\right\}$ NMR spectrum of $\mathbf{1 k}$ in $\mathrm{CDCl}_{3}$ with $0.05 \% \mathrm{v} / \mathrm{v}$ TMS (100 MHz)

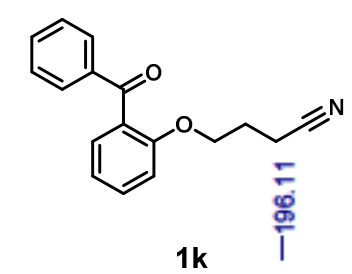

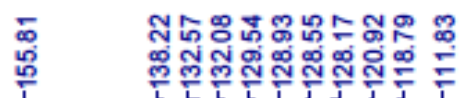

1k

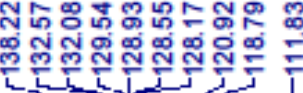

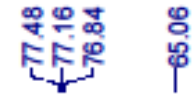

孪

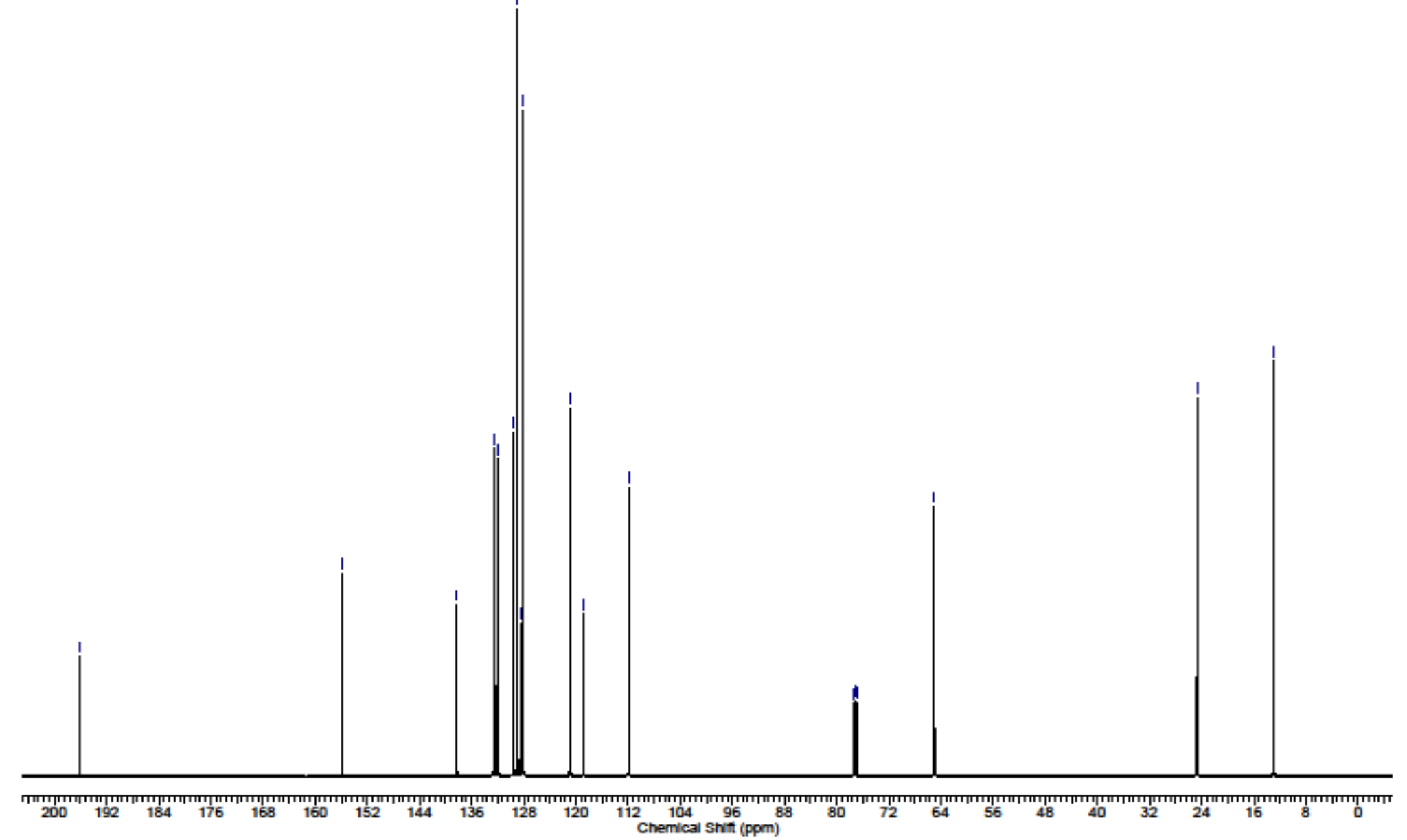


${ }^{1} \mathrm{H}$ NMR spectrum of 11 in $\mathrm{CDCl}_{3}$ with $0.05 \% \mathrm{v} / \mathrm{v}$ TMS (400 MHz)

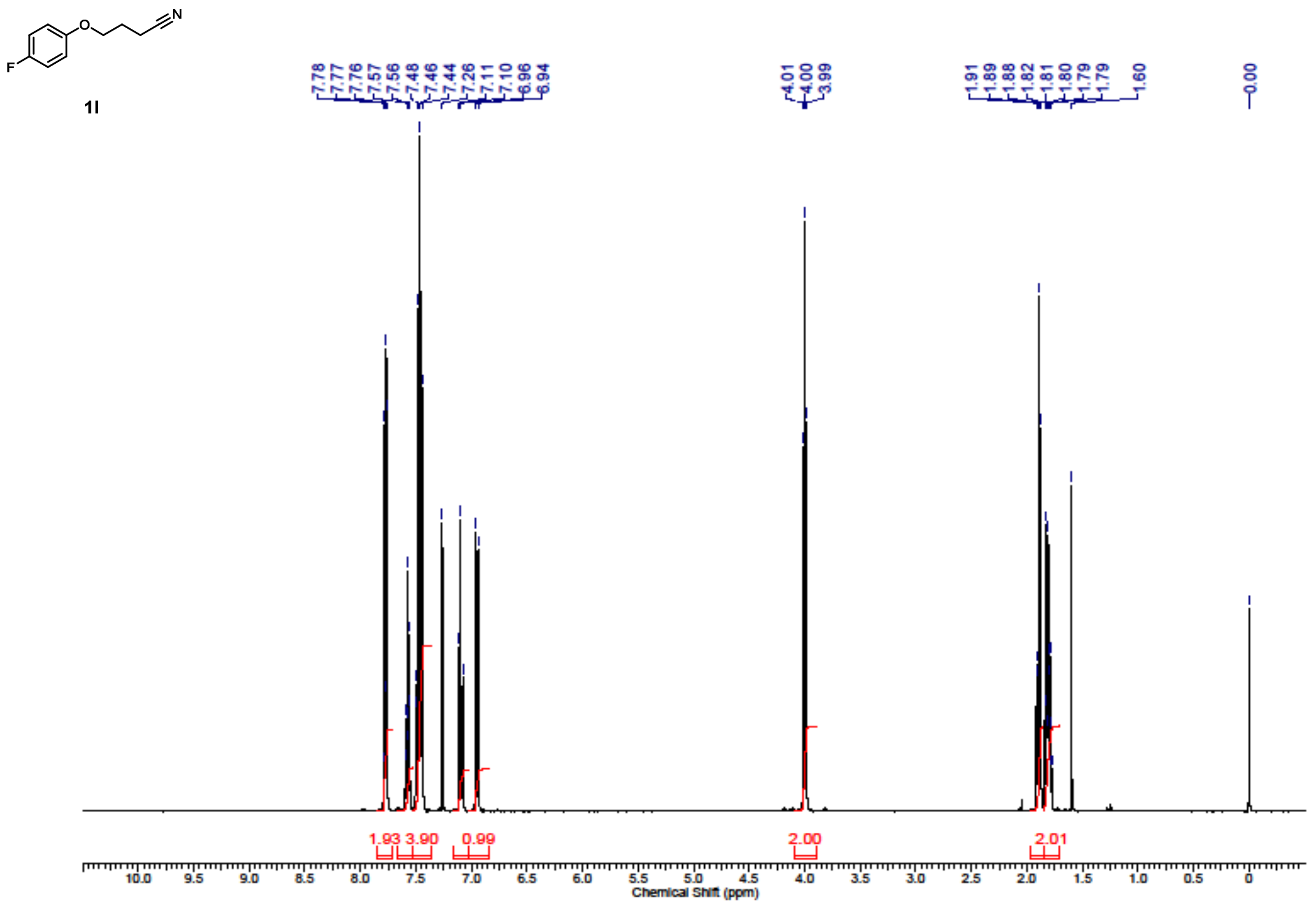


${ }^{13} \mathrm{C}\left\{{ }^{1} \mathrm{H}\right\}$ NMR spectrum of $\mathbf{1 1}$ in $\mathrm{CDCl}_{3}$ with $0.05 \% \mathrm{v} / \mathrm{v}$ TMS (100 MHz)

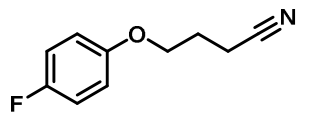

11

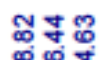

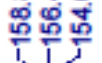

추ำ주유

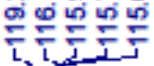

,

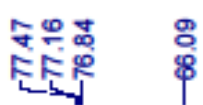

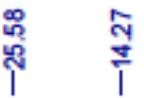

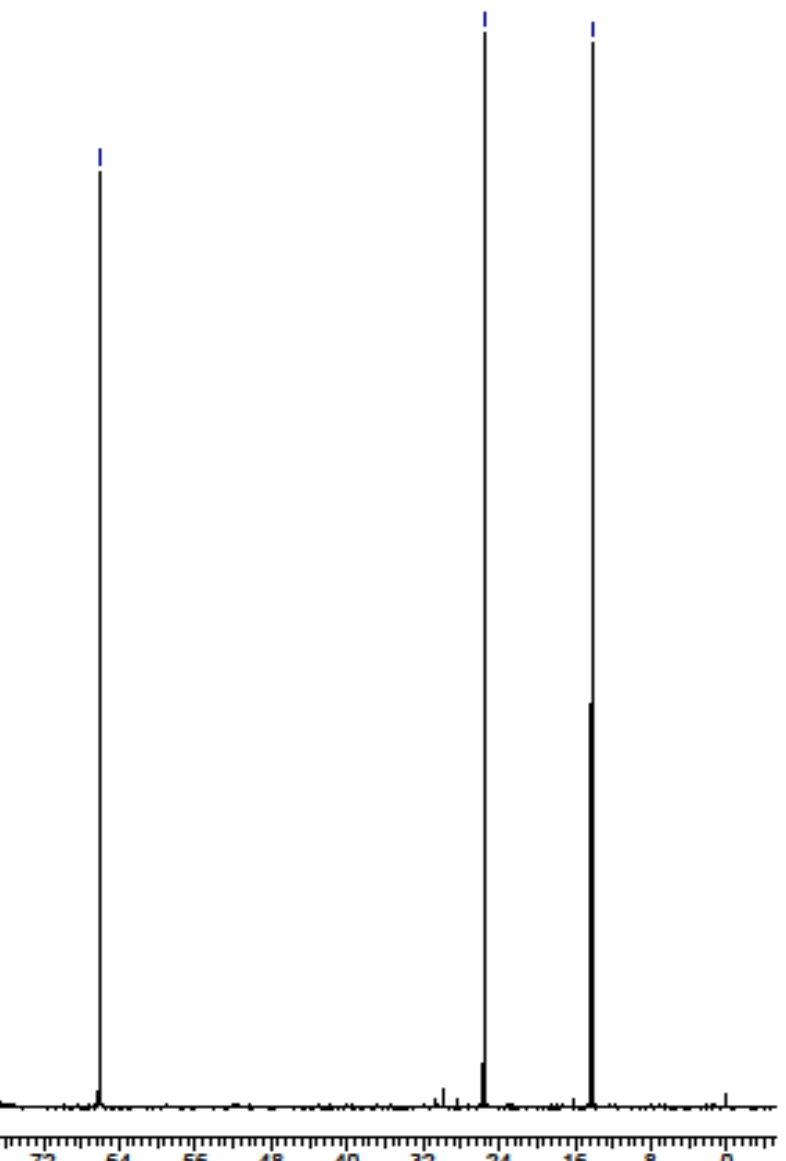




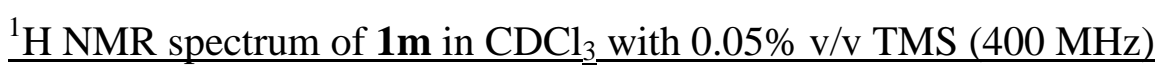

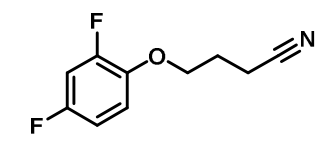

$1 \mathrm{~m}$

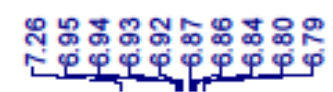

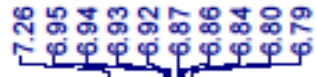

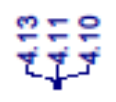

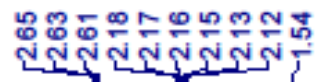

$1.99 \quad 2.01$

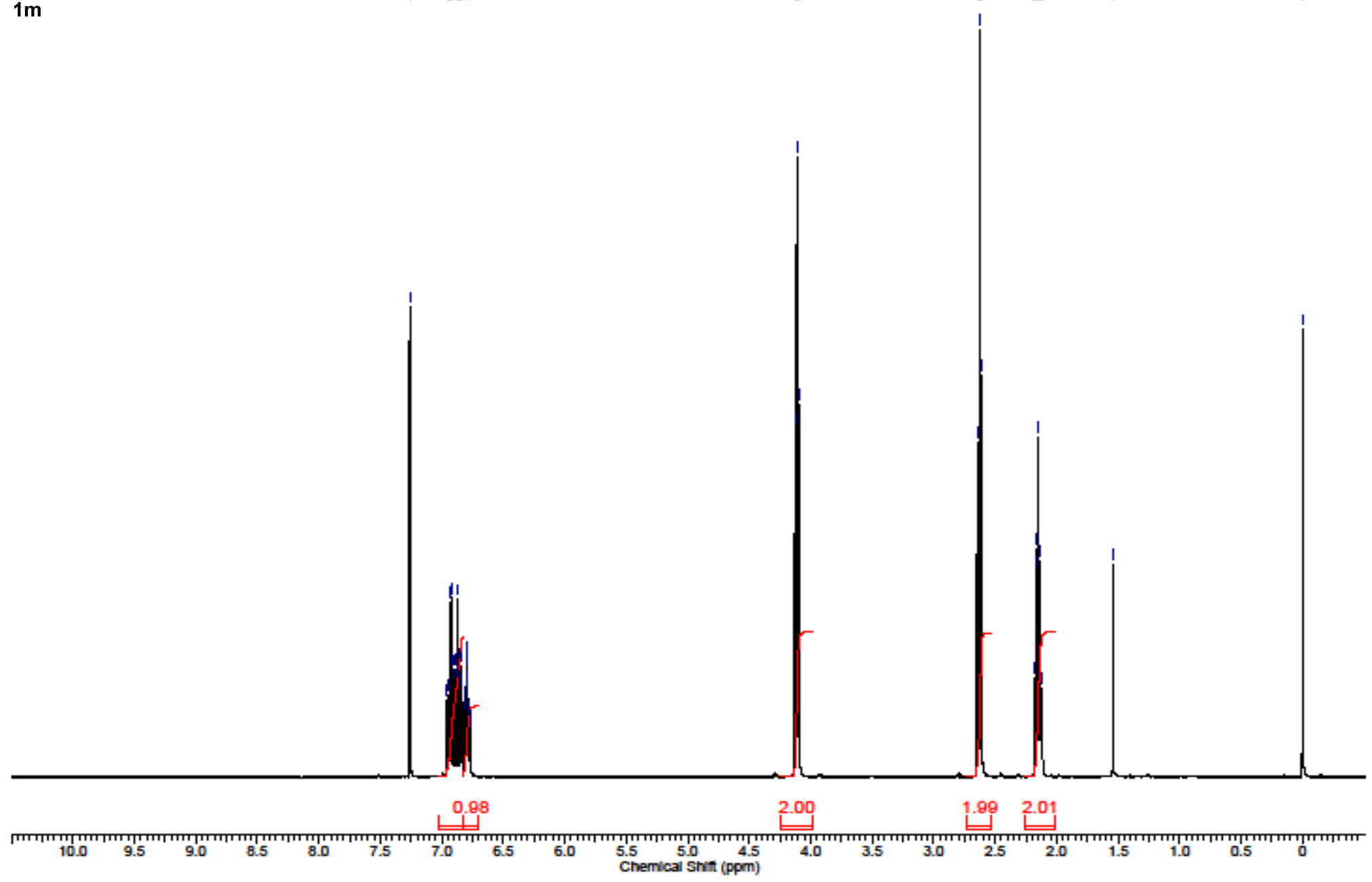


${ }^{13} \mathrm{C}\left\{{ }^{1} \mathrm{H}\right\}$ NMR spectrum of $\mathbf{1 m}$ in $\mathrm{CDCl}_{3}$ with $0.05 \% \mathrm{v} / \mathrm{v}$ TMS $(100 \mathrm{MHz})$

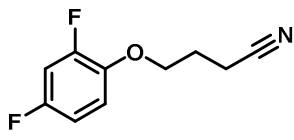

$1 \mathrm{~m}$

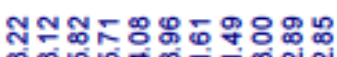

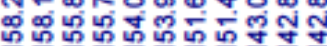

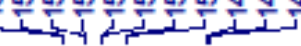

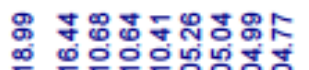

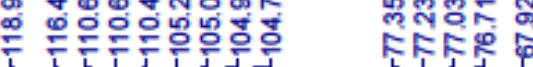

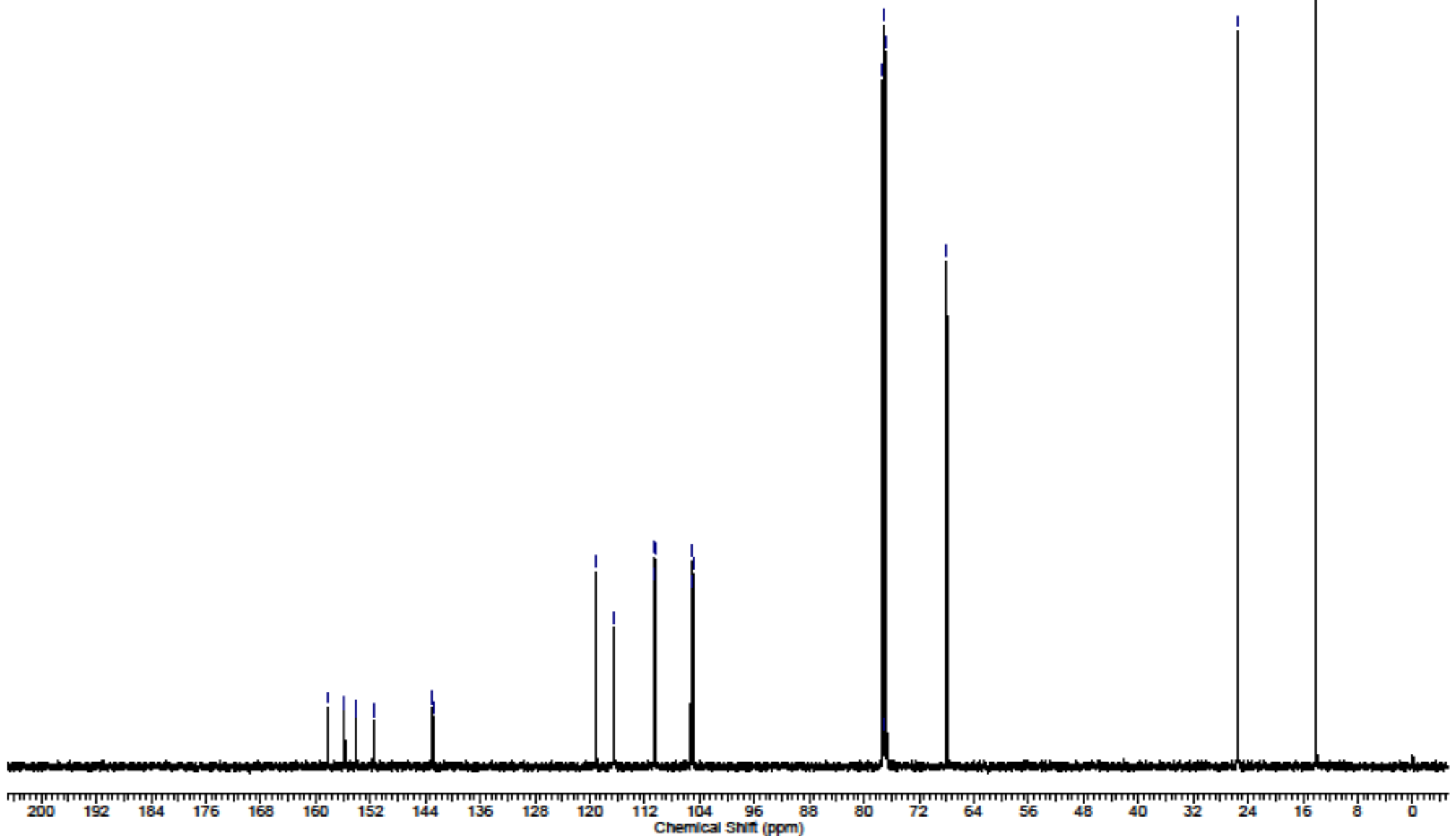


${ }^{1} \mathrm{H}$ NMR spectrum of $\mathbf{1 n}$ in $\mathrm{CDCl}_{3}$ with $0.05 \% \mathrm{v} / \mathrm{v}$ TMS (400 MHz)

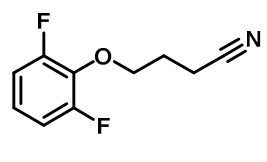

1n

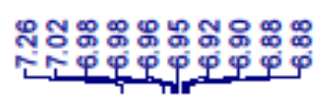

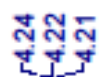

ind

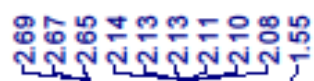

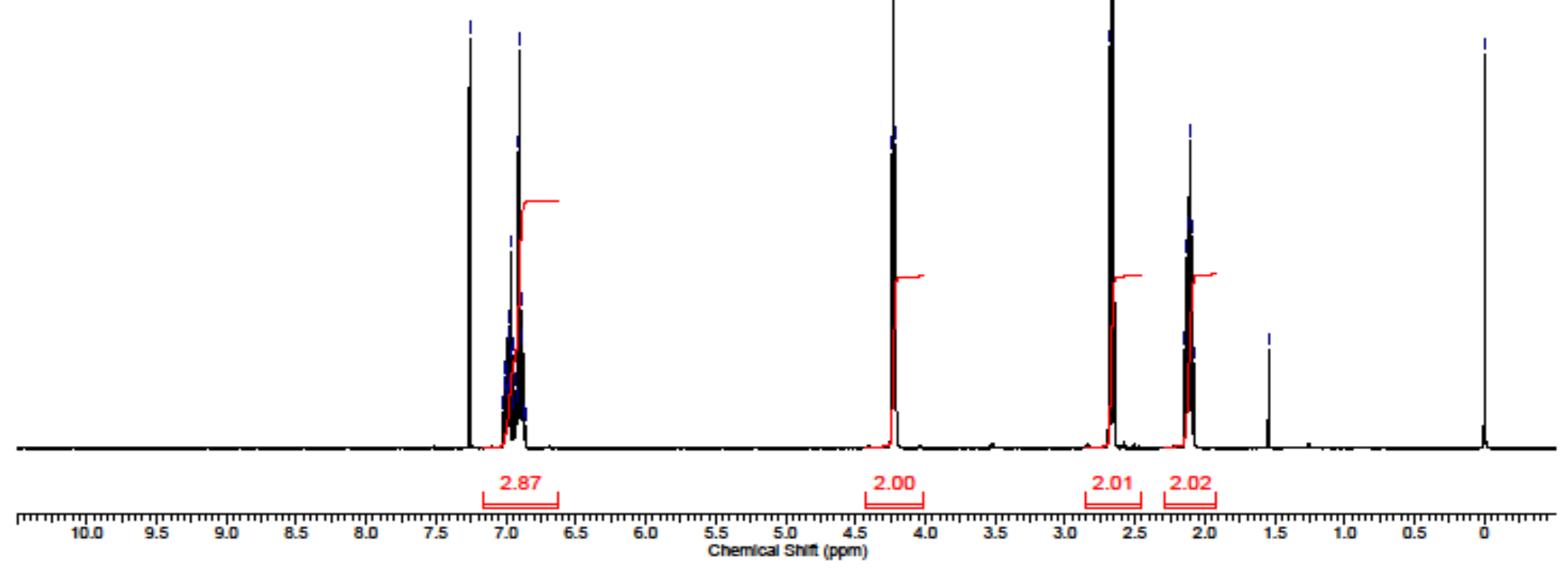


$\left.{ }^{13} \mathrm{C}^{1}{ }^{1} \mathrm{H}\right\}$ NMR spectrum of $1 \mathrm{n}$ in $\mathrm{CDCl}_{3}$ with $0.05 \%$ v/v TMS (100 MHz)

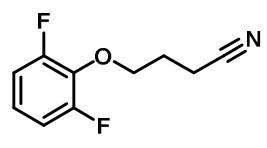

1n

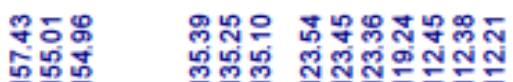

फํㄴ문

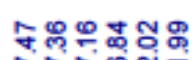

EFF日勺

네

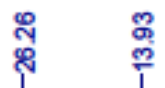

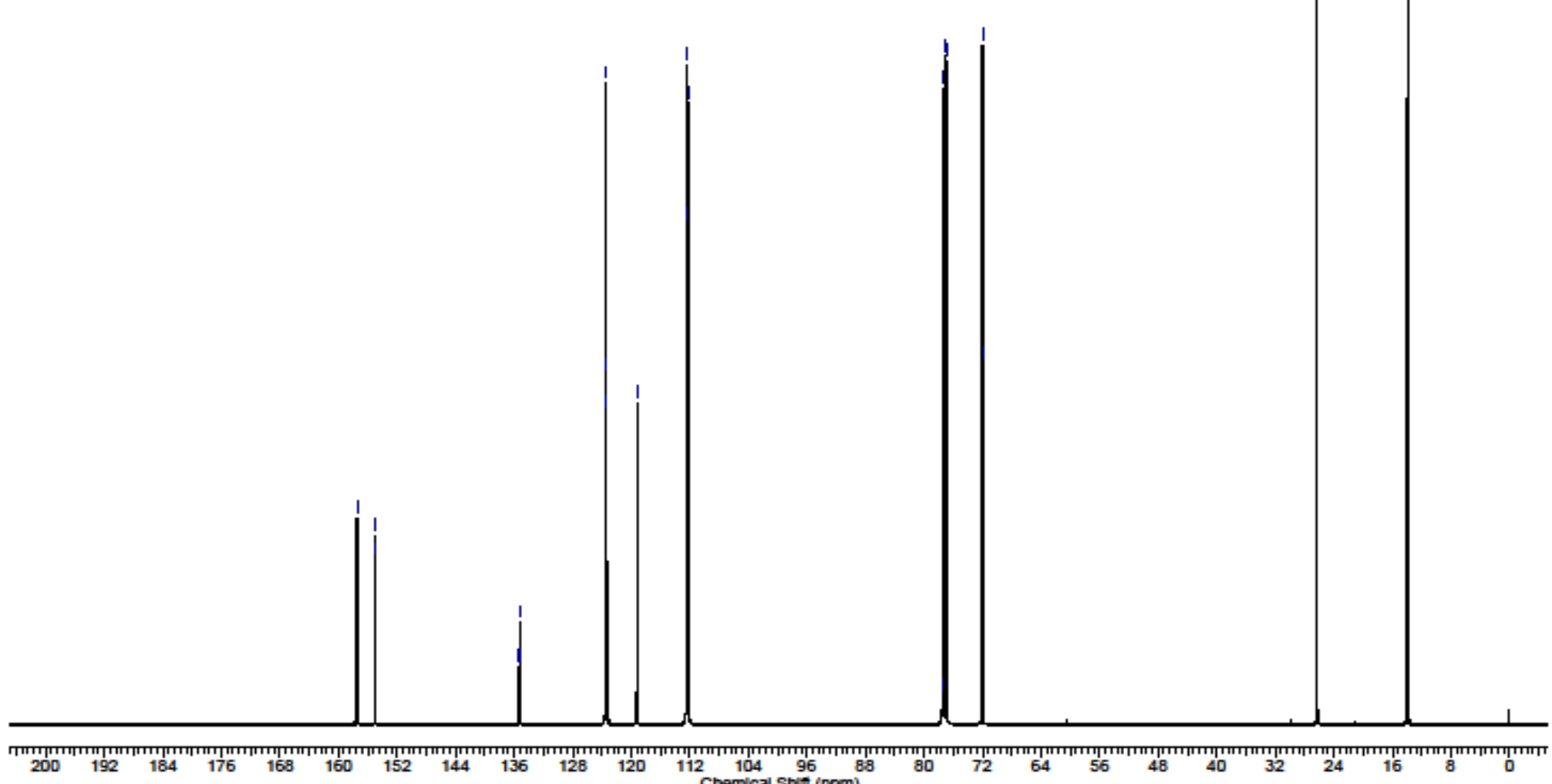


${ }^{1} \mathrm{H}$ NMR spectrum of 10 in $\mathrm{CDCl}_{3}$ with $0.05 \% \mathrm{v} / \mathrm{v}$ TMS $(400 \mathrm{MHz})$

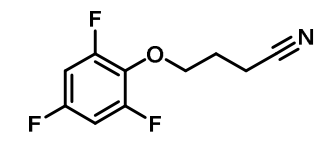

10

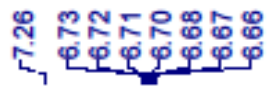

$$
\frac{\infty}{\dot{t}}=\frac{\infty}{\dot{t}}
$$

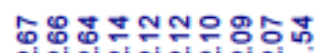

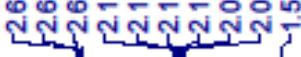

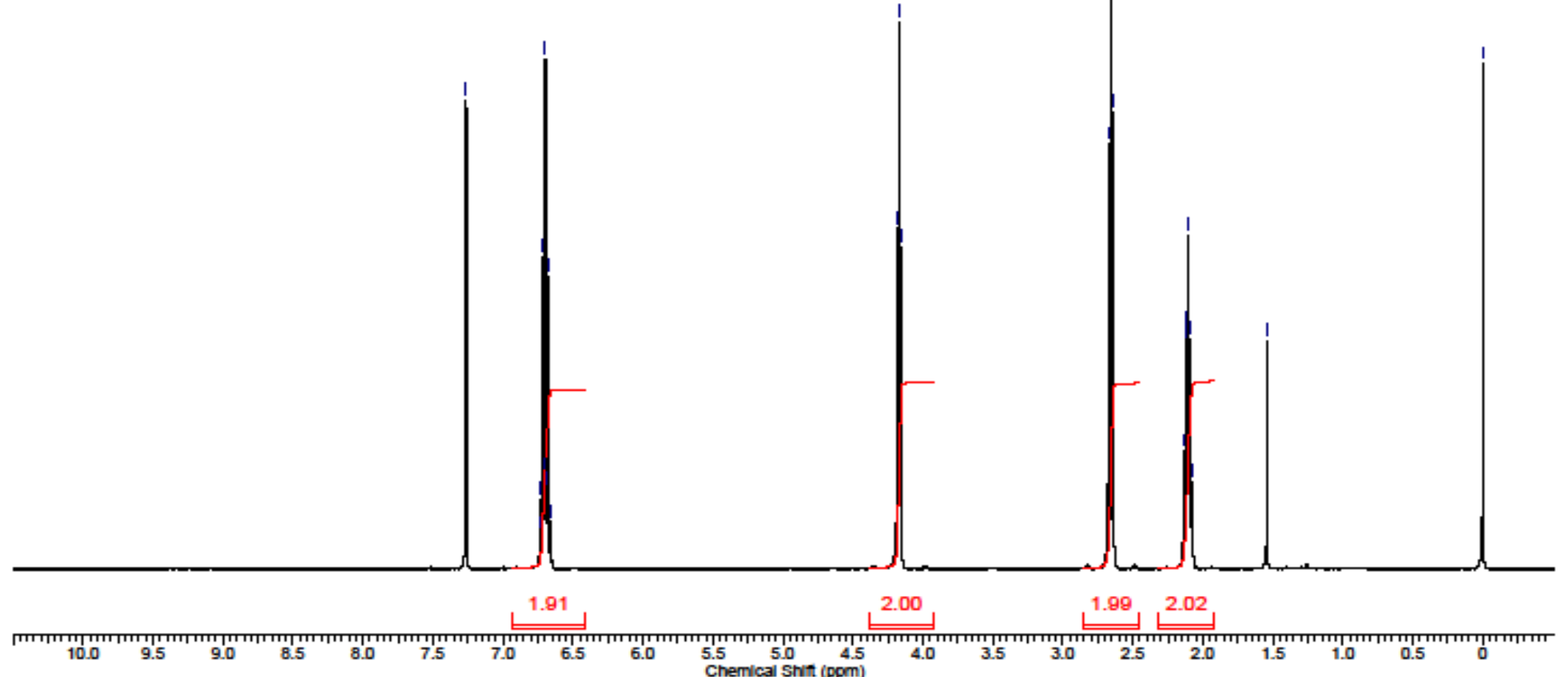


${ }^{13} \mathrm{C}\left\{{ }^{1} \mathrm{H}\right\}$ NMR spectrum of 10 in $\mathrm{CDCl}_{3}$ with $0.05 \% \mathrm{v} / \mathrm{v}$ TMS (100 MHz)

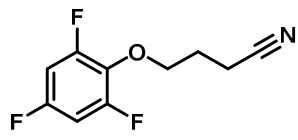

10

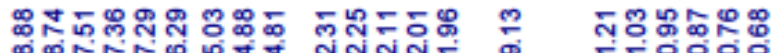

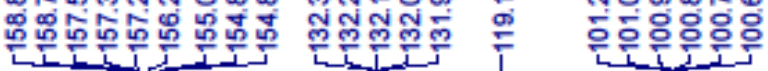

융ำ

EFEDT

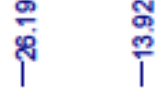

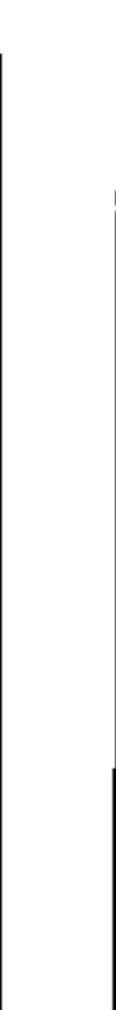

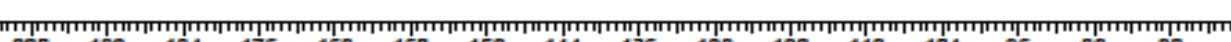

Chemical snit 96 
${ }^{1} \mathrm{H}$ NMR spectrum of $1 \mathrm{p}$ in $\mathrm{CDCl}_{3}$ with $0.05 \% \mathrm{v} / \mathrm{v}$ TMS $(400 \mathrm{MHz})$
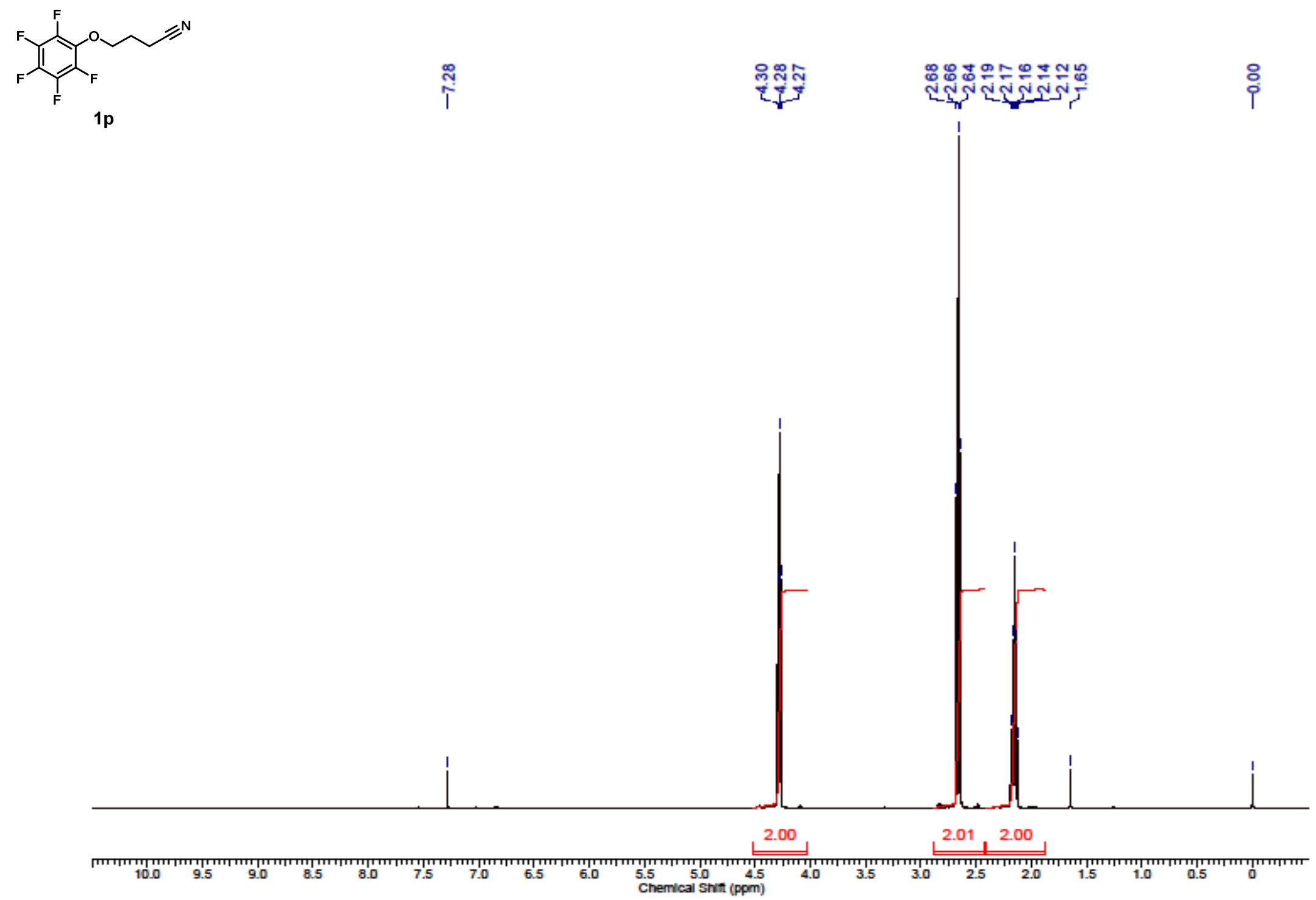
$\left.{ }^{13} \mathrm{C}^{1}{ }^{1} \mathrm{H}\right\}$ NMR spectrum of $\mathbf{1 p}$ in $\mathrm{CDCl}_{3}$ with $0.05 \% \mathrm{v} / \mathrm{v}$ TMS (100 MHz)

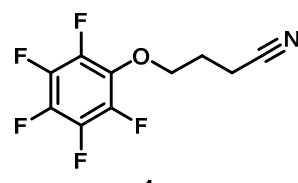

ำำำำ

$1 p$

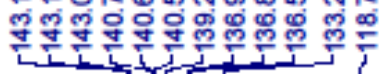

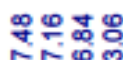

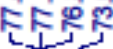

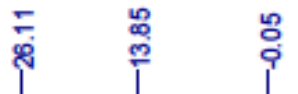
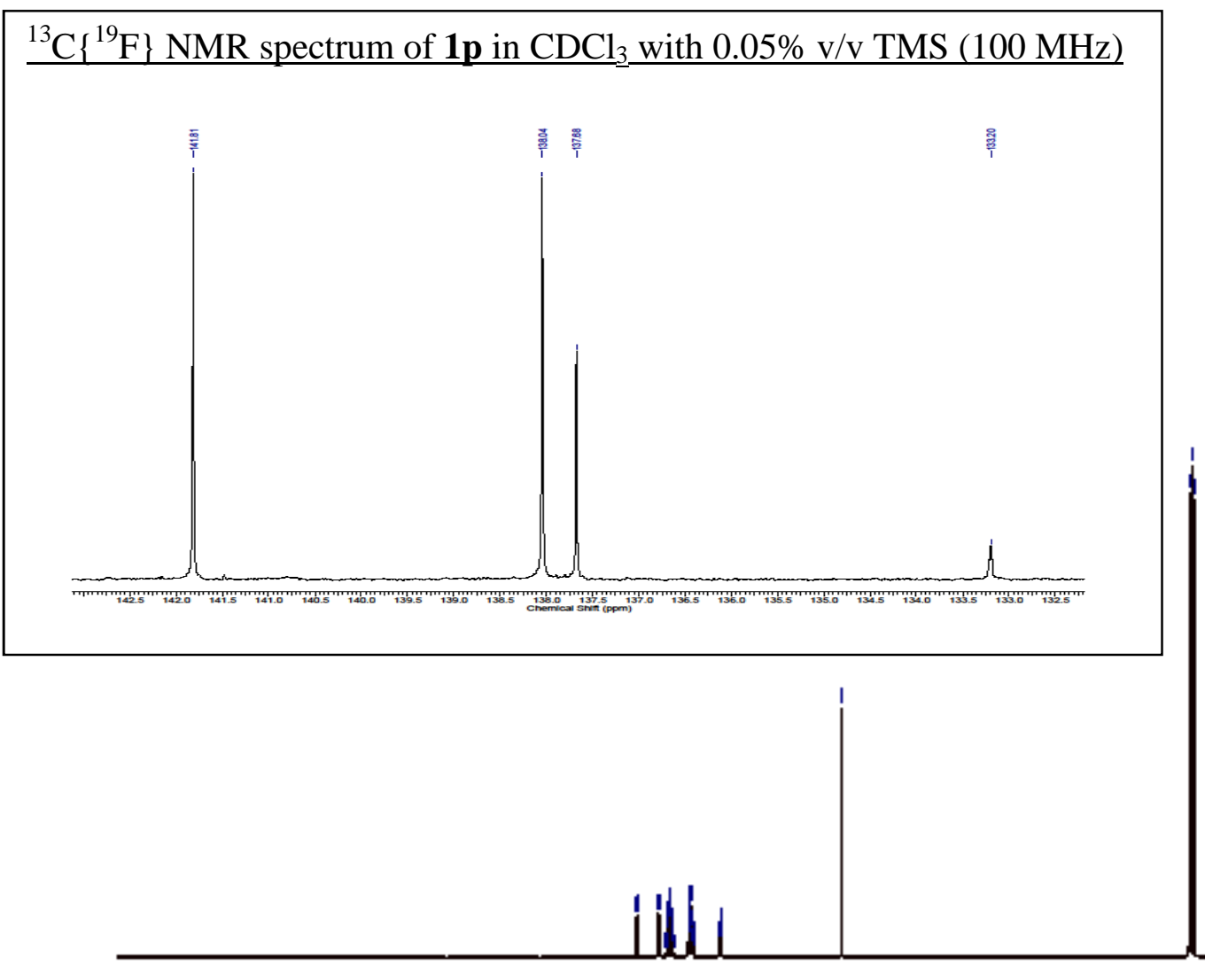

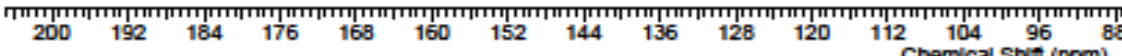
- 
${ }^{1} \mathrm{H}$ NMR spectrum of $1 \mathrm{q}$ in $\mathrm{CDCl}_{3}$ with $0.05 \% \mathrm{v} / \mathrm{v}$ TMS $(400 \mathrm{MHz})$

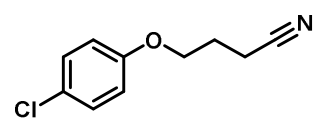

$1 q$

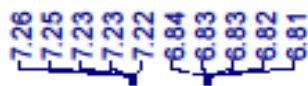

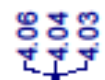

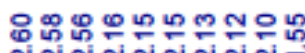

กำงสำกับง

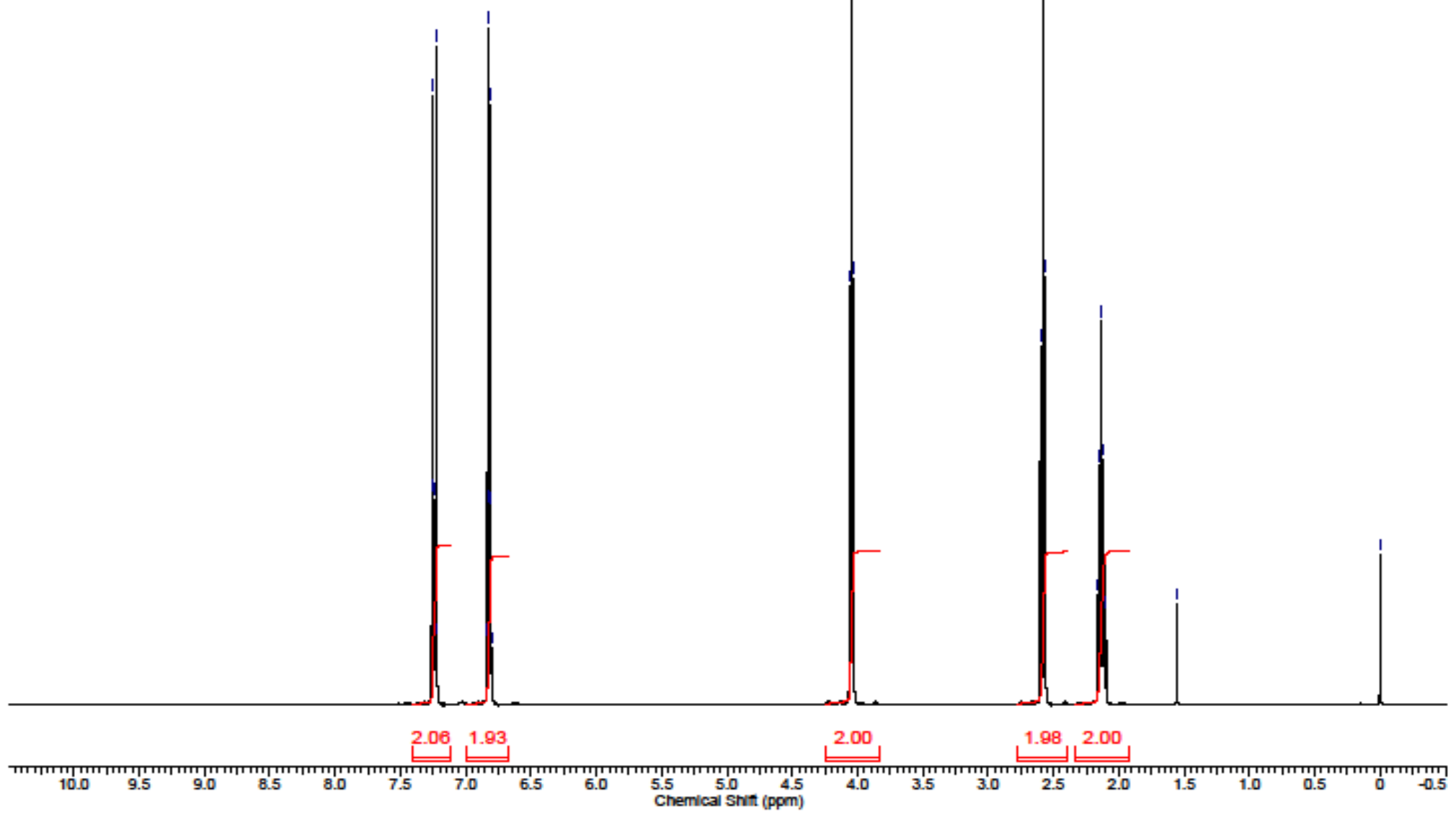


${ }^{13} \mathrm{C}\left\{{ }^{1} \mathrm{H}\right\}$ NMR spectrum of $1 \mathbf{1 q}$ in $\mathrm{CDCl}_{3}$ with $0.05 \% \mathrm{v} / \mathrm{v}$ MS $(100 \mathrm{MHz})$

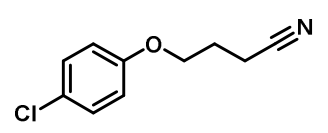

$1 q$
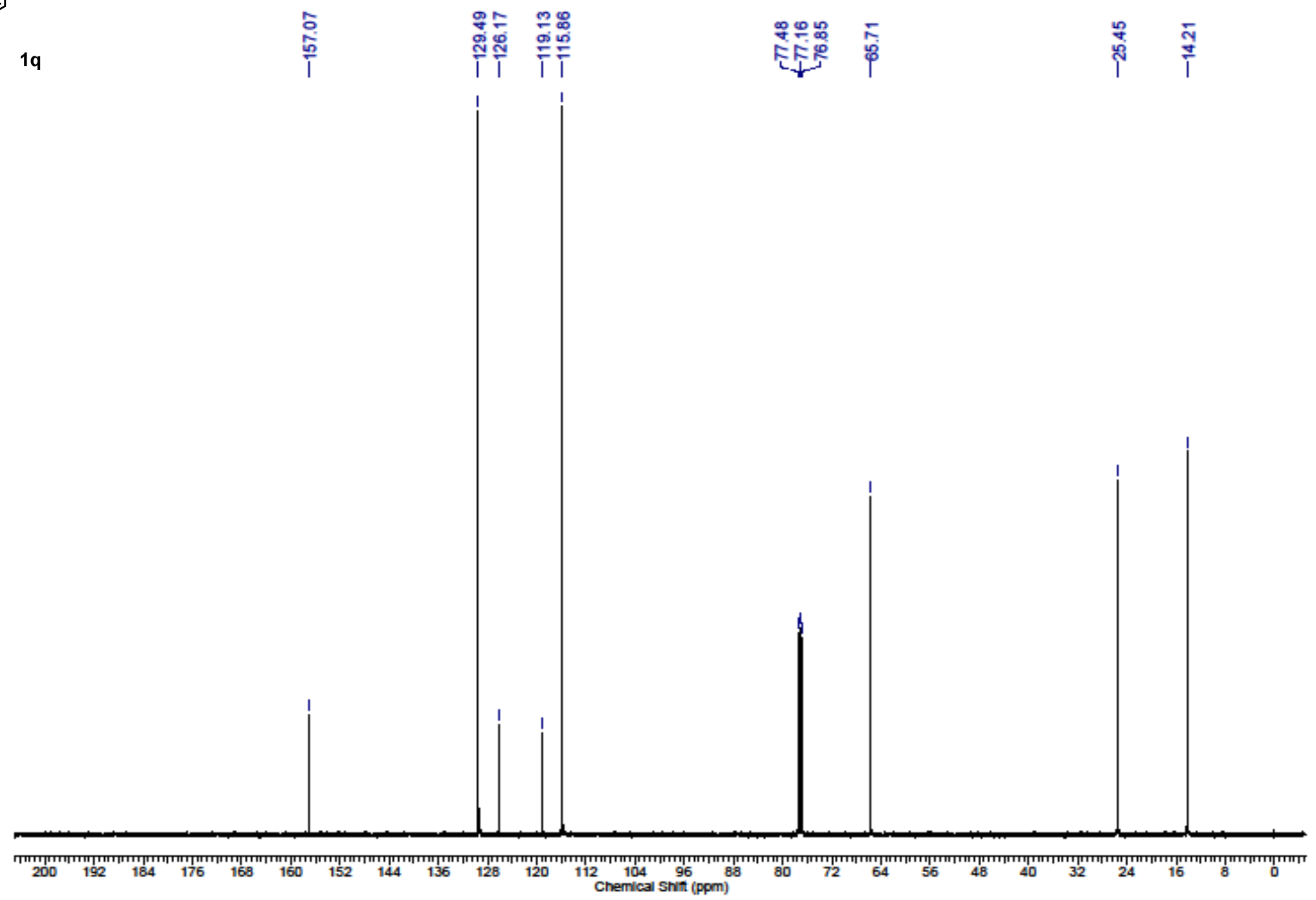

S40 
${ }^{1} \mathrm{H}$ NMR spectrum of $1 \mathbf{r}$ in $\mathrm{CDCl}_{3}$ with $0.05 \% \mathrm{v} / \mathrm{v}$ TMS $(400 \mathrm{MHz})$

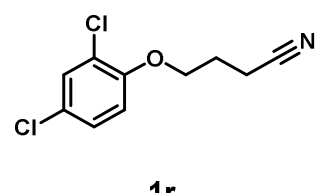

$1 \mathrm{r}$

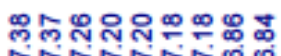

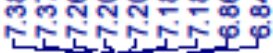

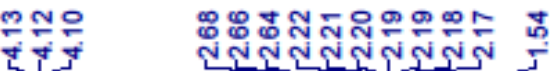

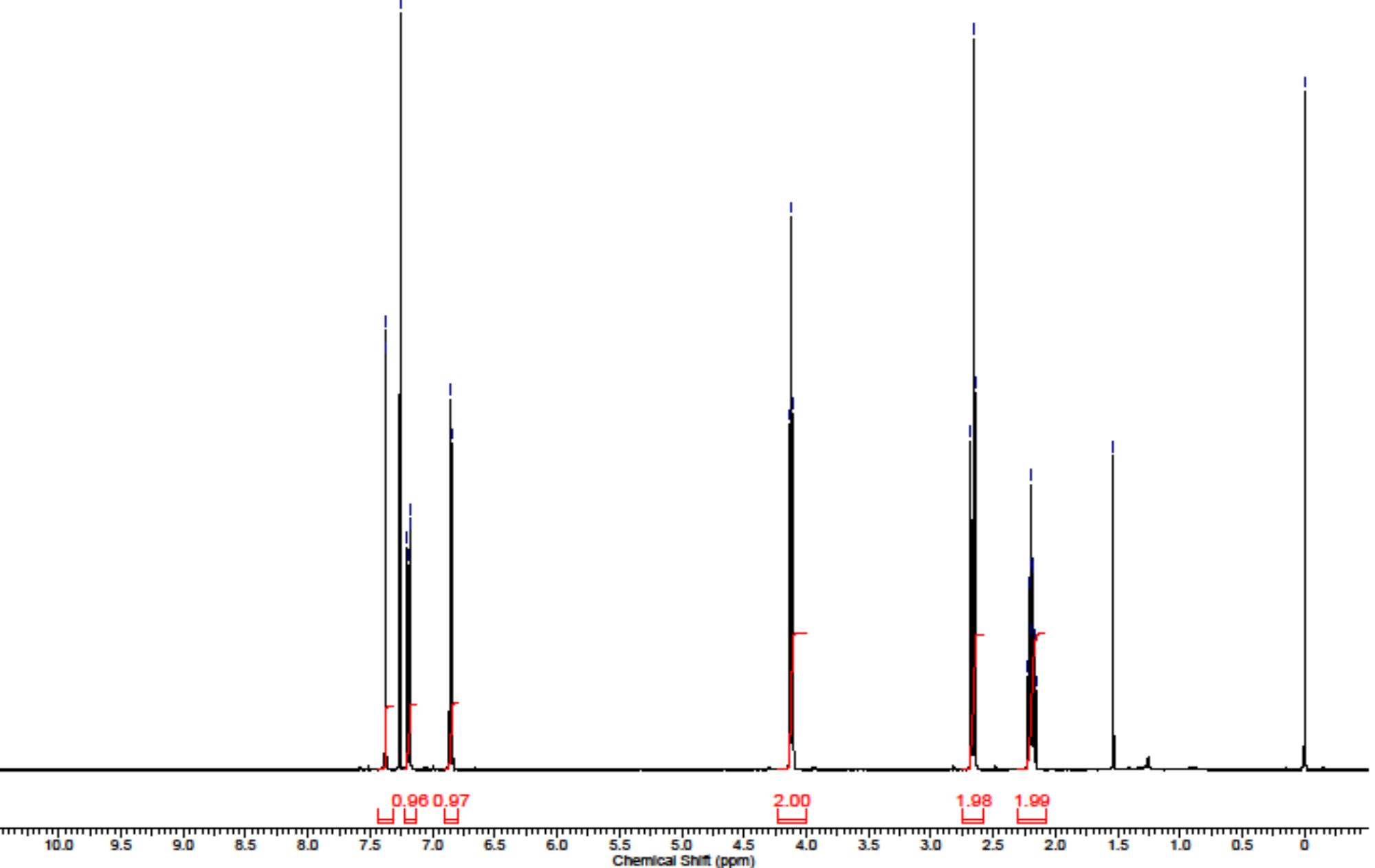




$$
\text { Jil }
$$


$\underline{{ }^{1} \mathrm{H} \text { NMR spectrum of } 1 \mathrm{~s} \text { in } \mathrm{CDCl}_{3}}$ with $0.05 \% \mathrm{v} / \mathrm{v}$ TMS (400 MHz)

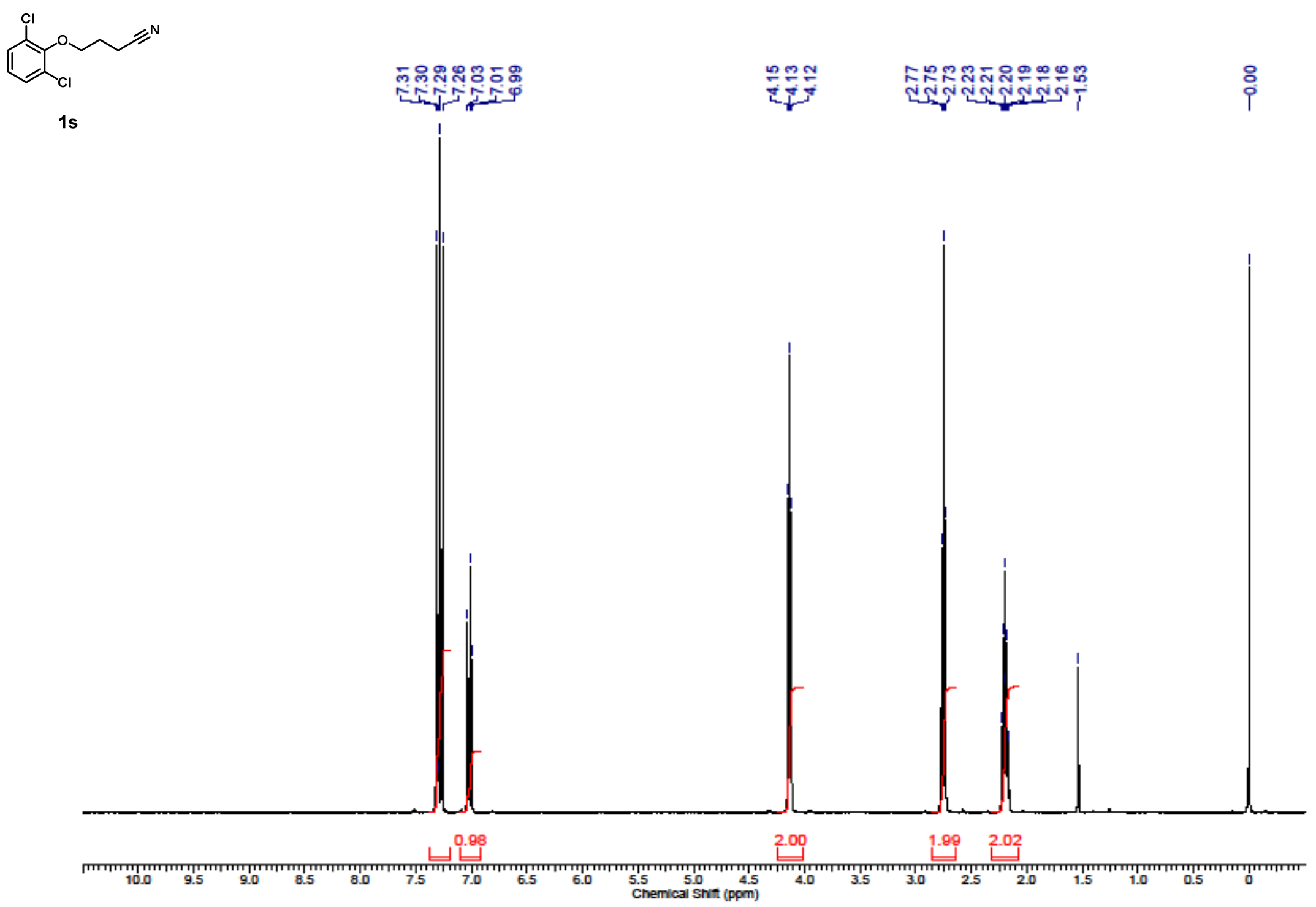




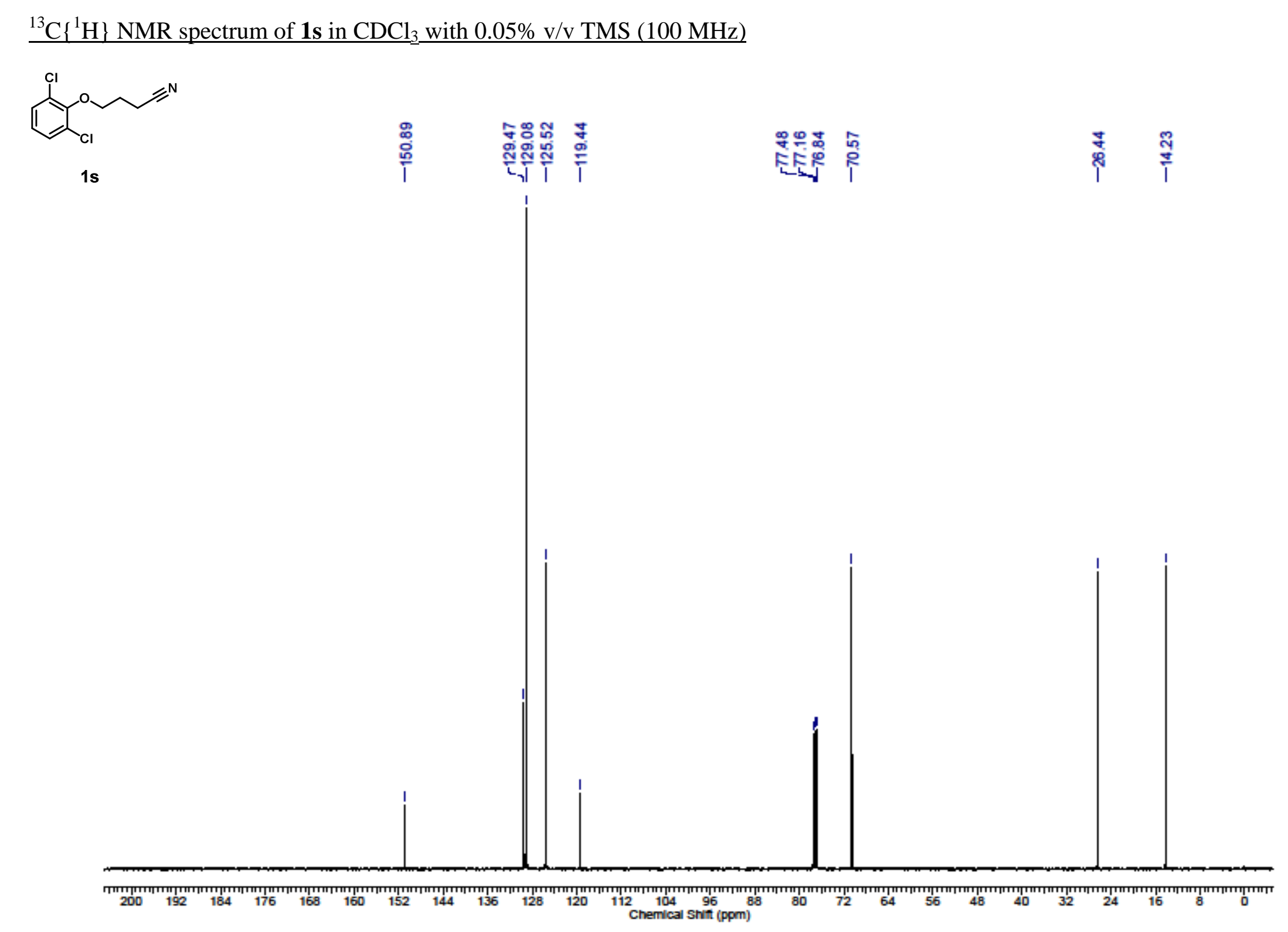

S44 
${ }^{1} \mathrm{H}$ NMR spectrum of $1 \mathrm{t}$ in $\mathrm{CDCl}_{3}$ with $0.05 \% \mathrm{v} / \mathrm{v}$ TMS $(400 \mathrm{MHz})$

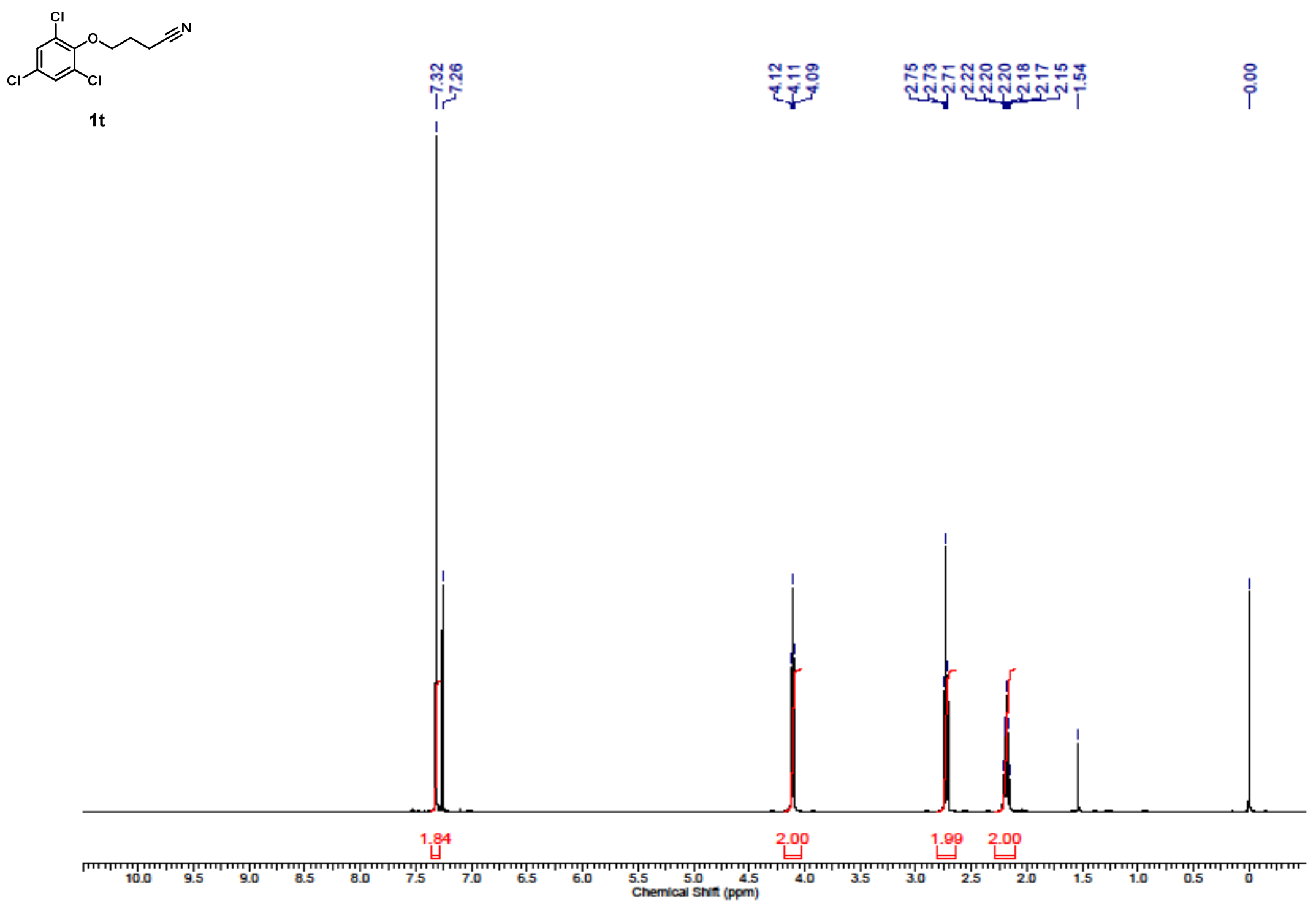




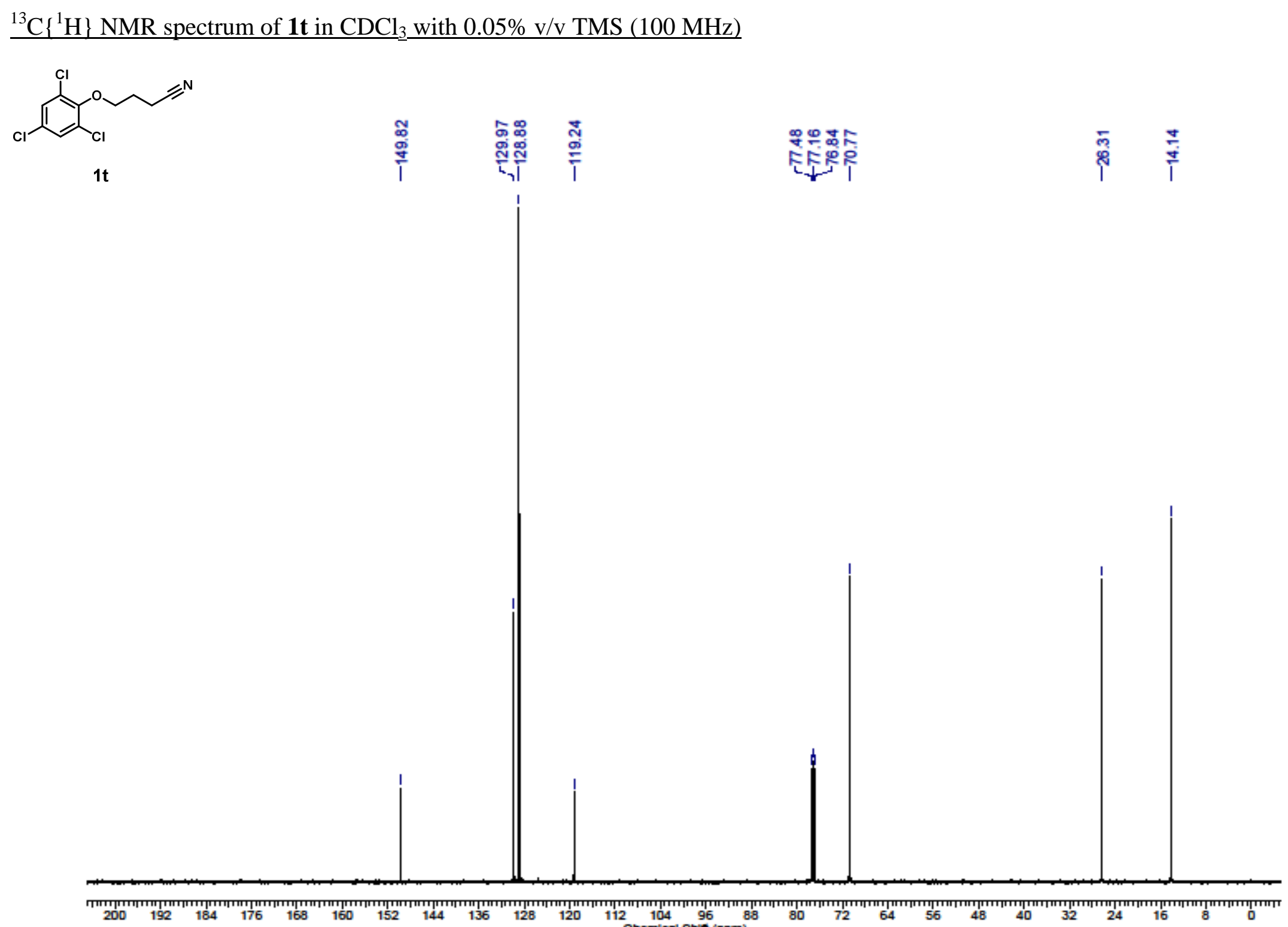

S46 
${ }^{1} \mathrm{H}$ NMR spectrum of $1 \mathrm{u}$ in $\mathrm{CDCl}_{3}$ with $0.05 \% \mathrm{v} / \mathrm{v}$ TMS $(400 \mathrm{MHz})$

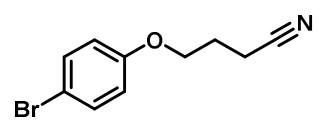

$1 \mathrm{u}$
밀

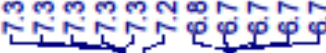

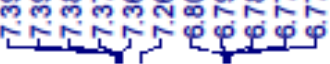

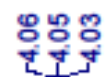

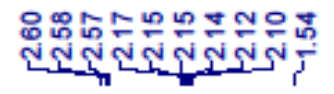

i̊

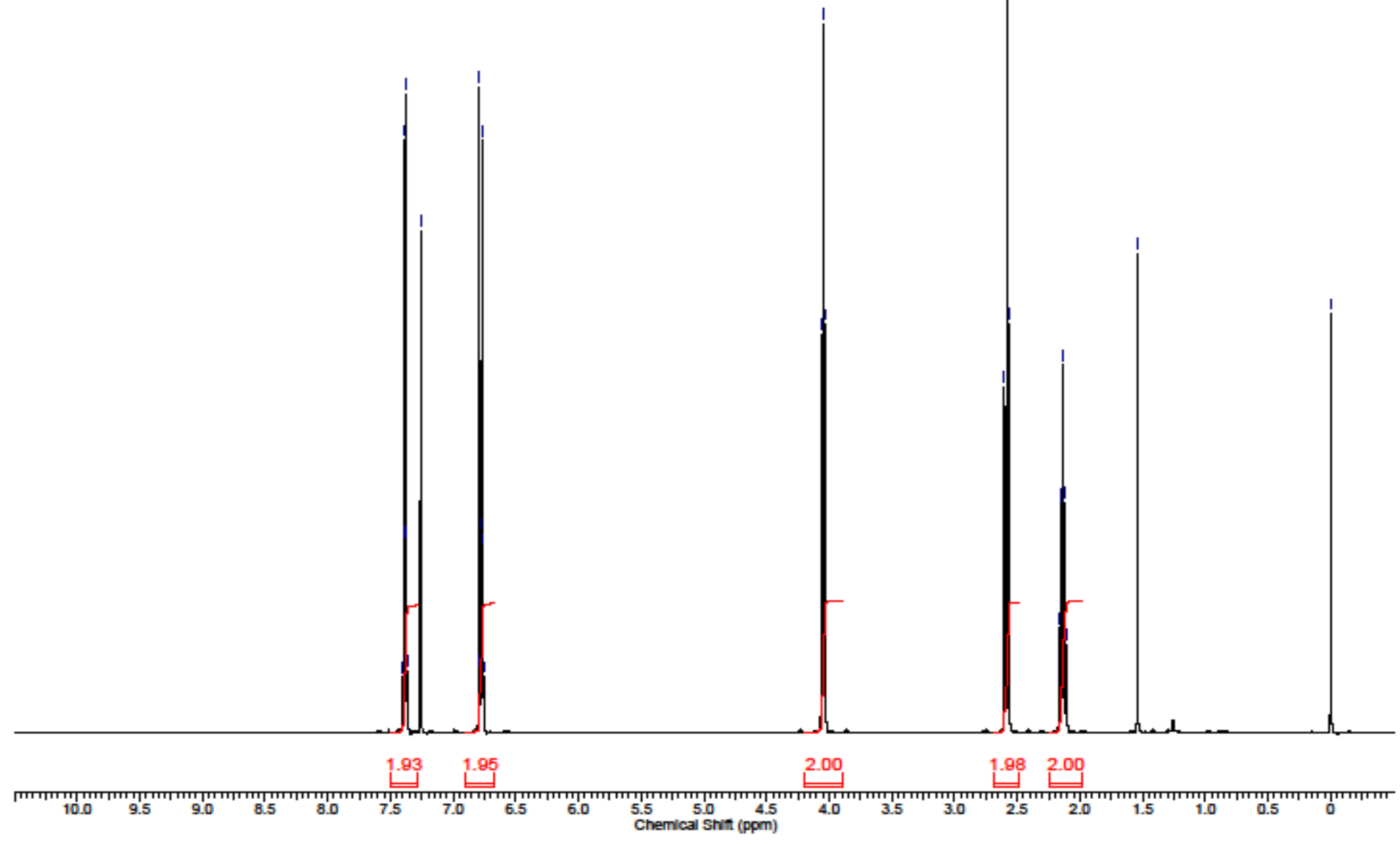


${ }^{13} \mathrm{C}\left\{{ }^{1} \mathrm{H}\right\}$ NMR spectrum of $\mathbf{1 u}$ in $\mathrm{CDCl}_{3}$ with $0.05 \%$ v/v TMS $(100 \mathrm{MHz})$

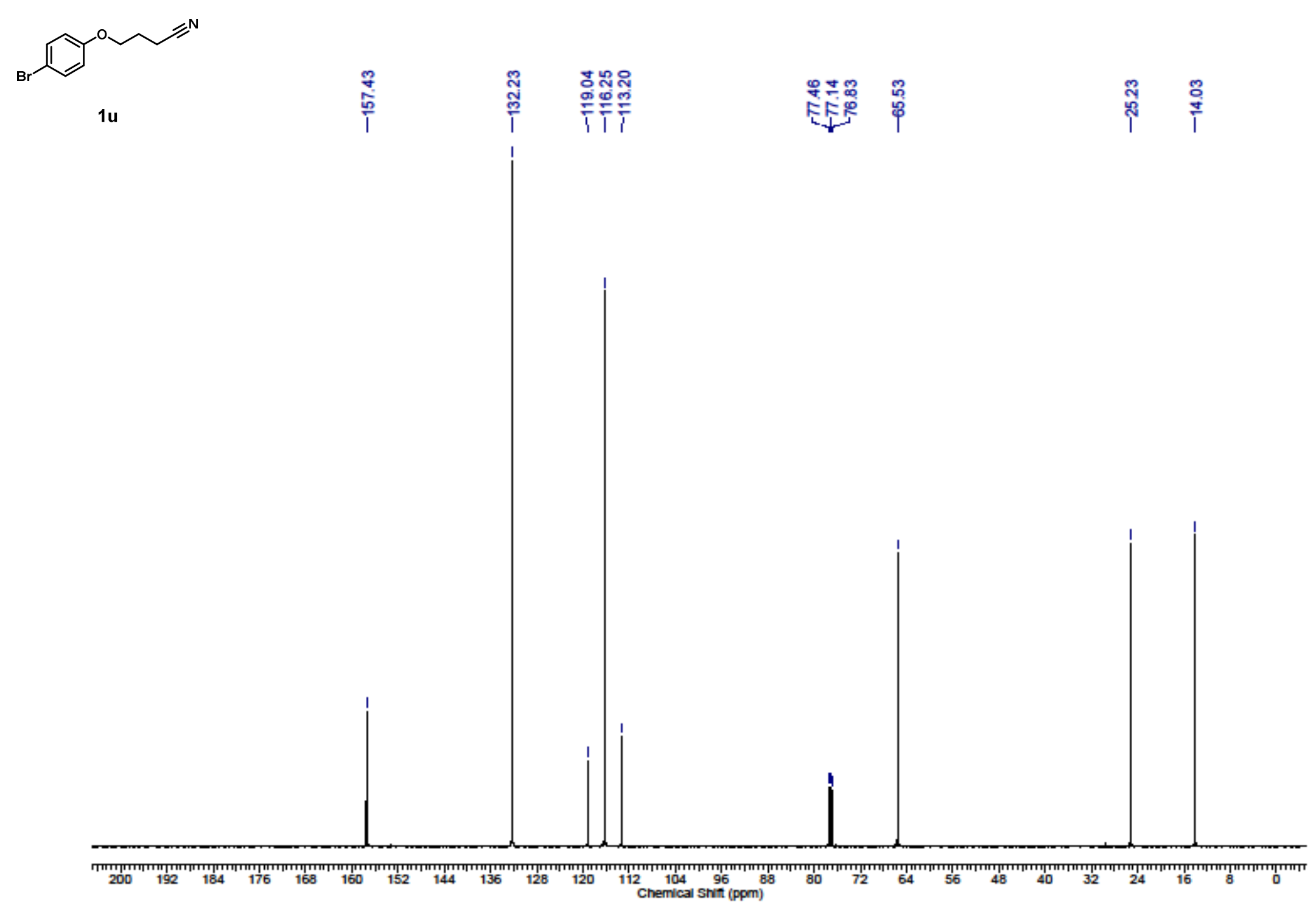

S48 
${ }^{1} \mathrm{H}$ NMR spectrum of $1 \mathrm{v}$ in $\mathrm{CDCl}_{3}$ with $0.05 \% \mathrm{v} / \mathrm{v}$ TMS $(400 \mathrm{MHz})$

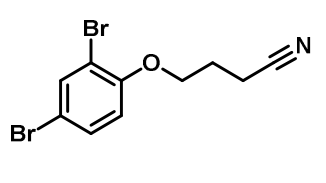

1v

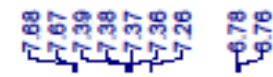

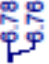

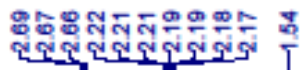

|
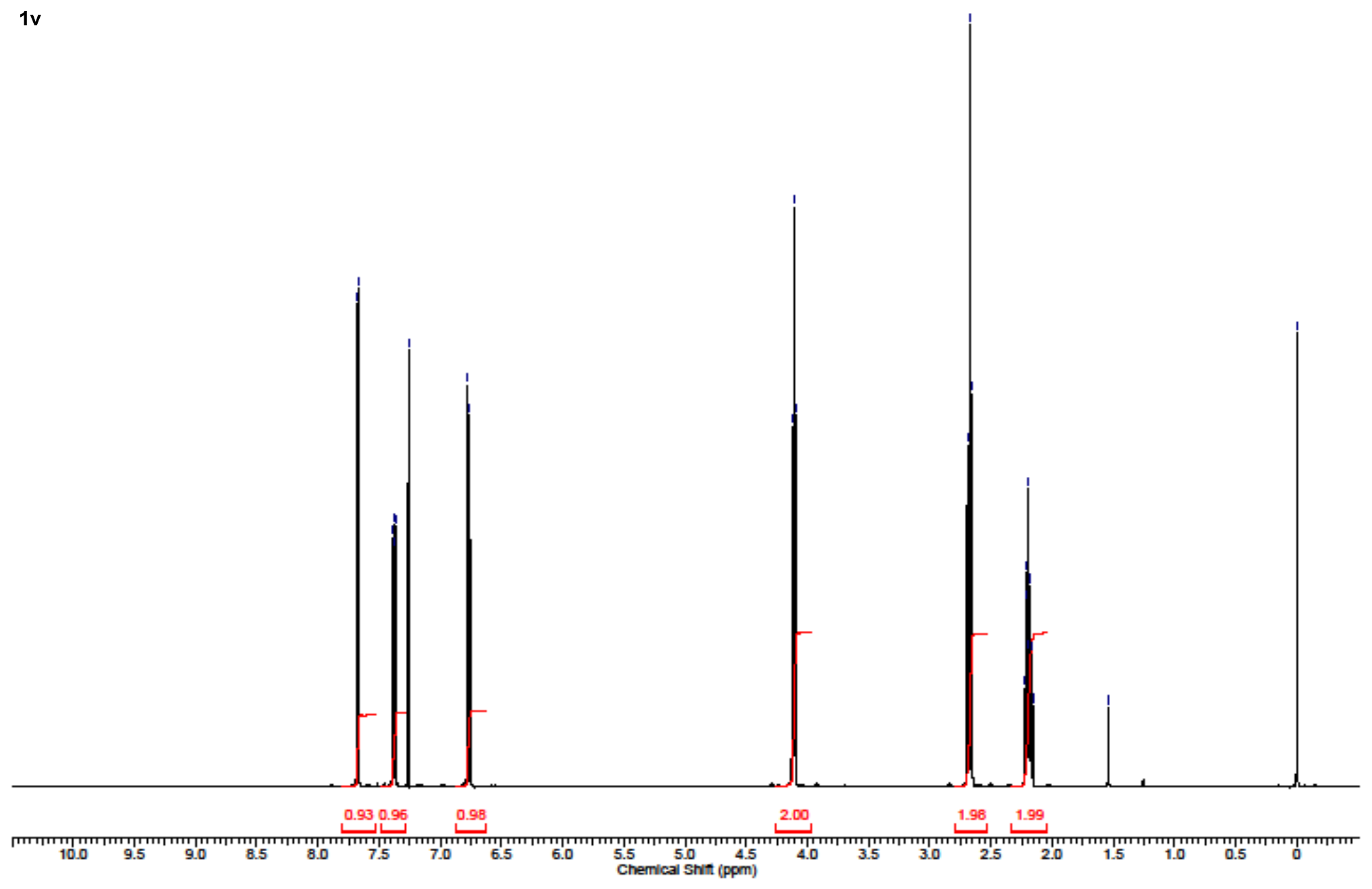
${ }^{13} \mathrm{C}\left\{{ }^{1} \mathrm{H}\right\}$ NMR spectrum of $\mathbf{1 v}$ in $\mathrm{CDCl}_{3}$ with $0.05 \% \mathrm{v} / \mathrm{v}$ TMS (100 MHz)

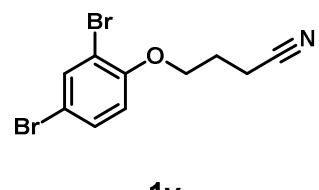

$1 v$

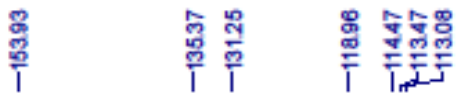

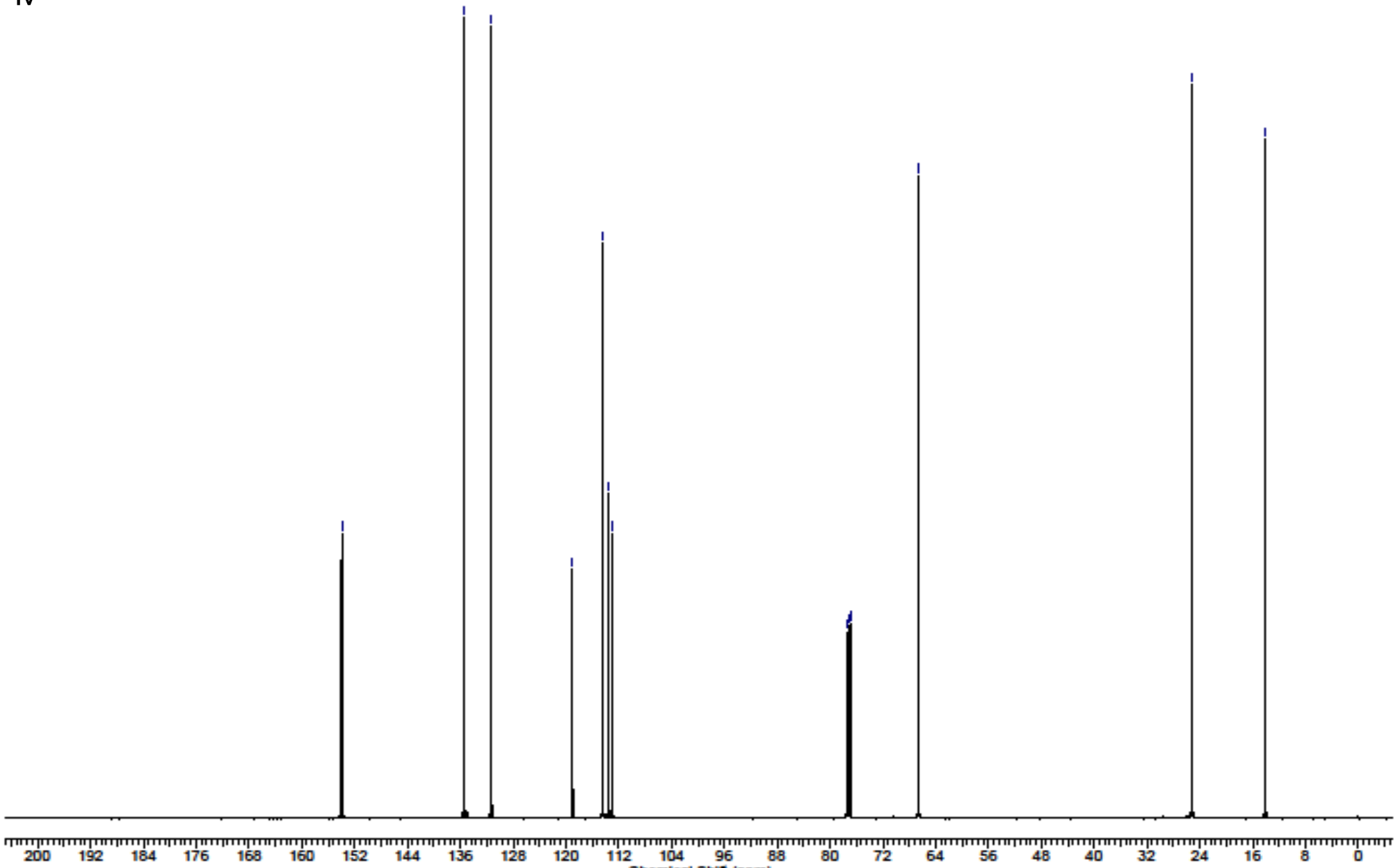

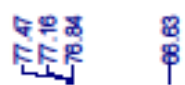

$\stackrel{8}{1} \frac{8}{1}$ 
${ }^{1} \mathrm{H}$ NMR spectrum of $\mathbf{1} \mathbf{w}$ in $\mathrm{CDCl}_{3}$ with $0.05 \% \mathrm{v} / \mathrm{v}$ TMS (400 MHz)

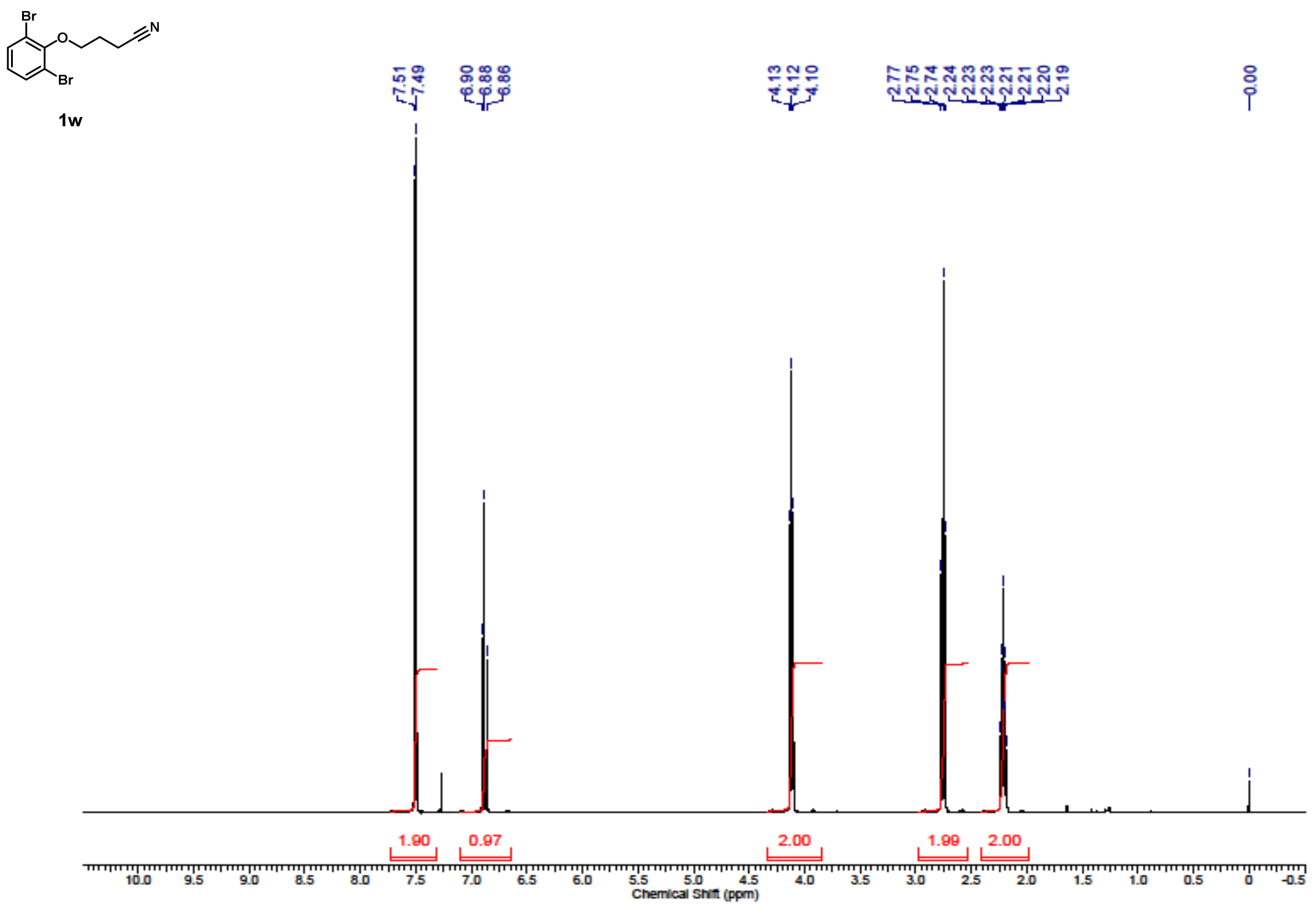


${ }^{13} \mathrm{C}\left\{{ }^{1} \mathrm{H}\right\}$ NMR spectrum of $\mathbf{1 w}$ in $\mathrm{CDCl}_{3}$ with $0.05 \% \mathrm{v} / \mathrm{v}$ TMS $(100 \mathrm{MHz})$

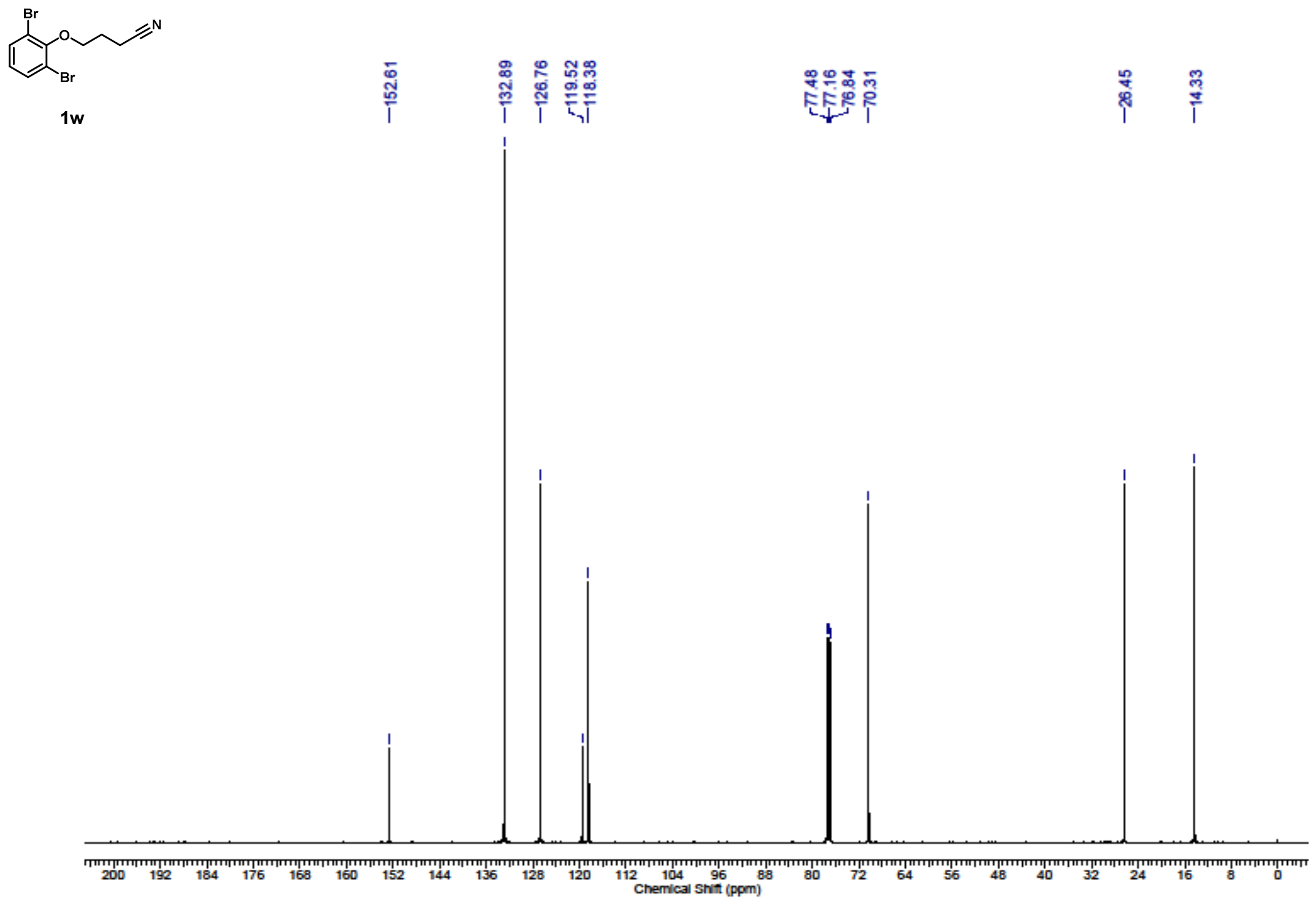


${ }^{1} \mathrm{H}$ NMR spectrum of $\mathbf{1} \mathbf{x}$ in $\mathrm{CDCl}_{3}$ with $0.05 \% \mathrm{v} / \mathrm{v}$ TMS $(400 \mathrm{MHz})$

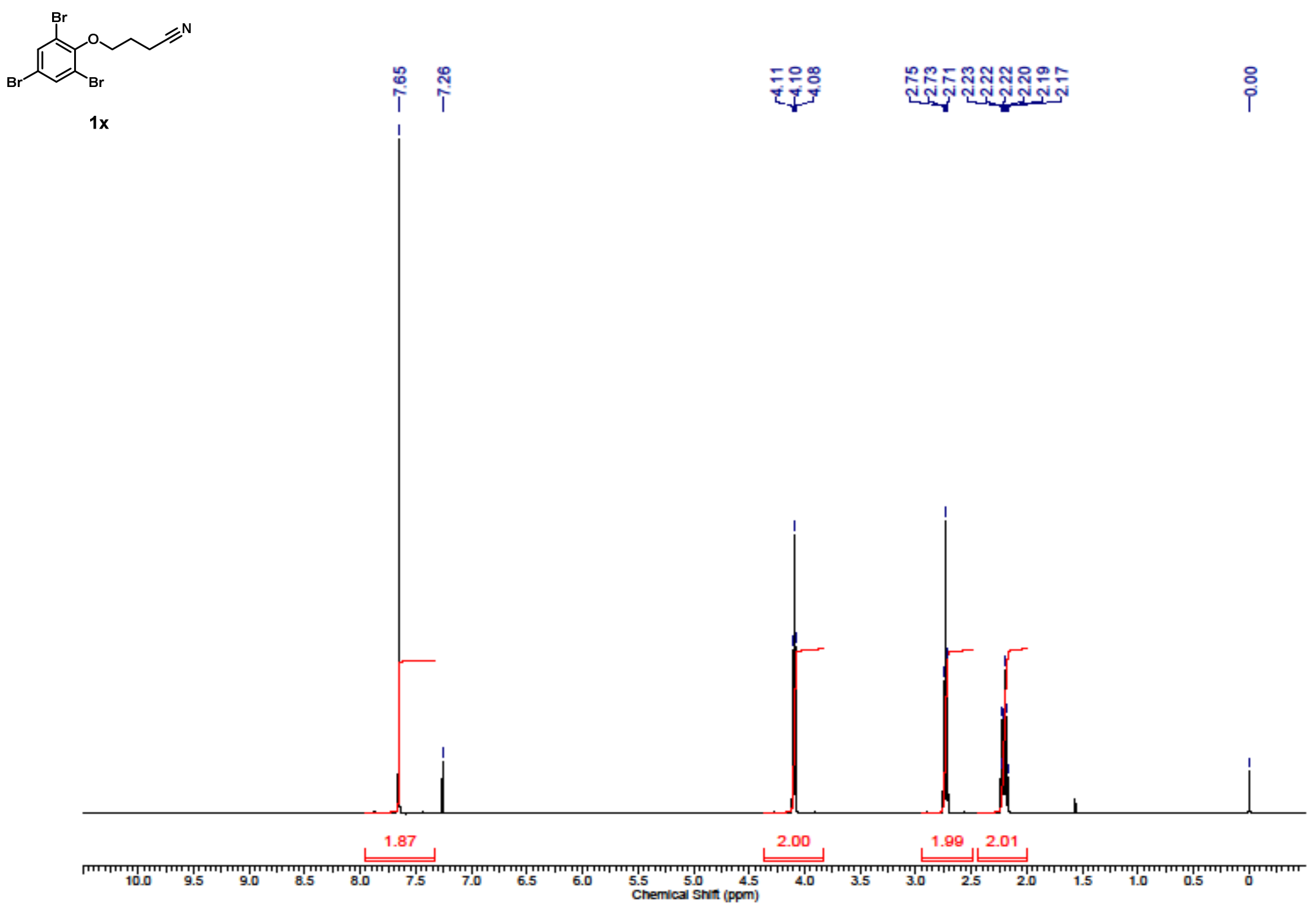


${ }^{13} \mathrm{C}\left\{{ }^{1} \mathrm{H}\right\}$ NMR spectrum of $\mathbf{1 x}$ in $\mathrm{CDCl}_{3}$ with $0.05 \% \mathrm{v} / \mathrm{v}$ TMS (100 MHz)
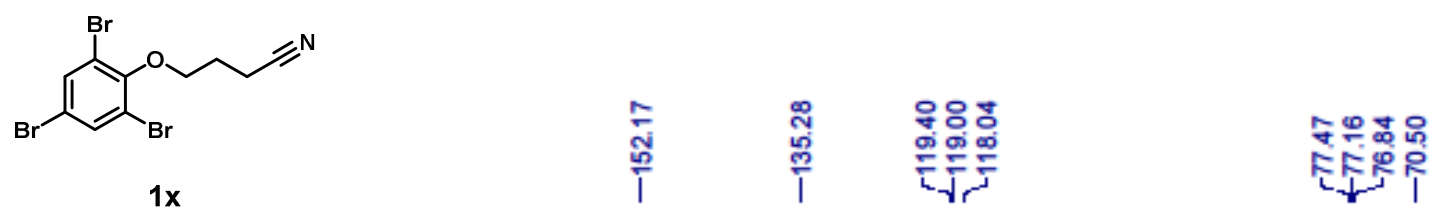

i

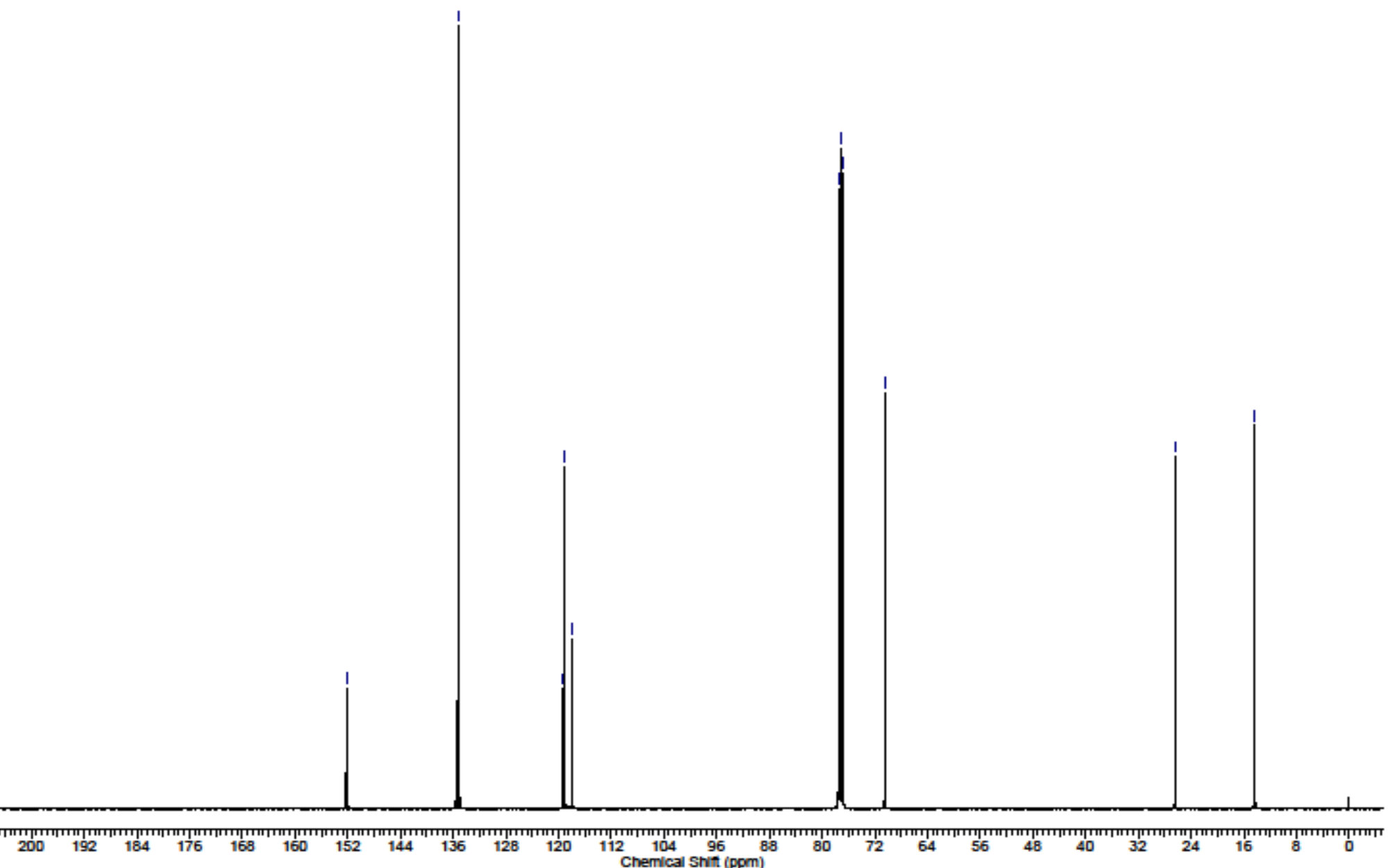


${ }^{1} \mathrm{H}$ NMR spectrum of $\mathbf{1 y}$ in $\mathrm{CDCl}_{3}$ with $0.05 \% \mathrm{v} / \mathrm{v}$ TMS (400 MHz)

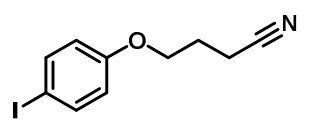

$1 y$

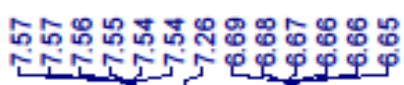

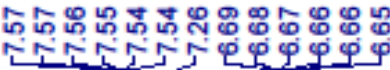

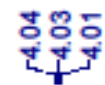

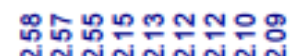

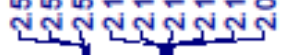

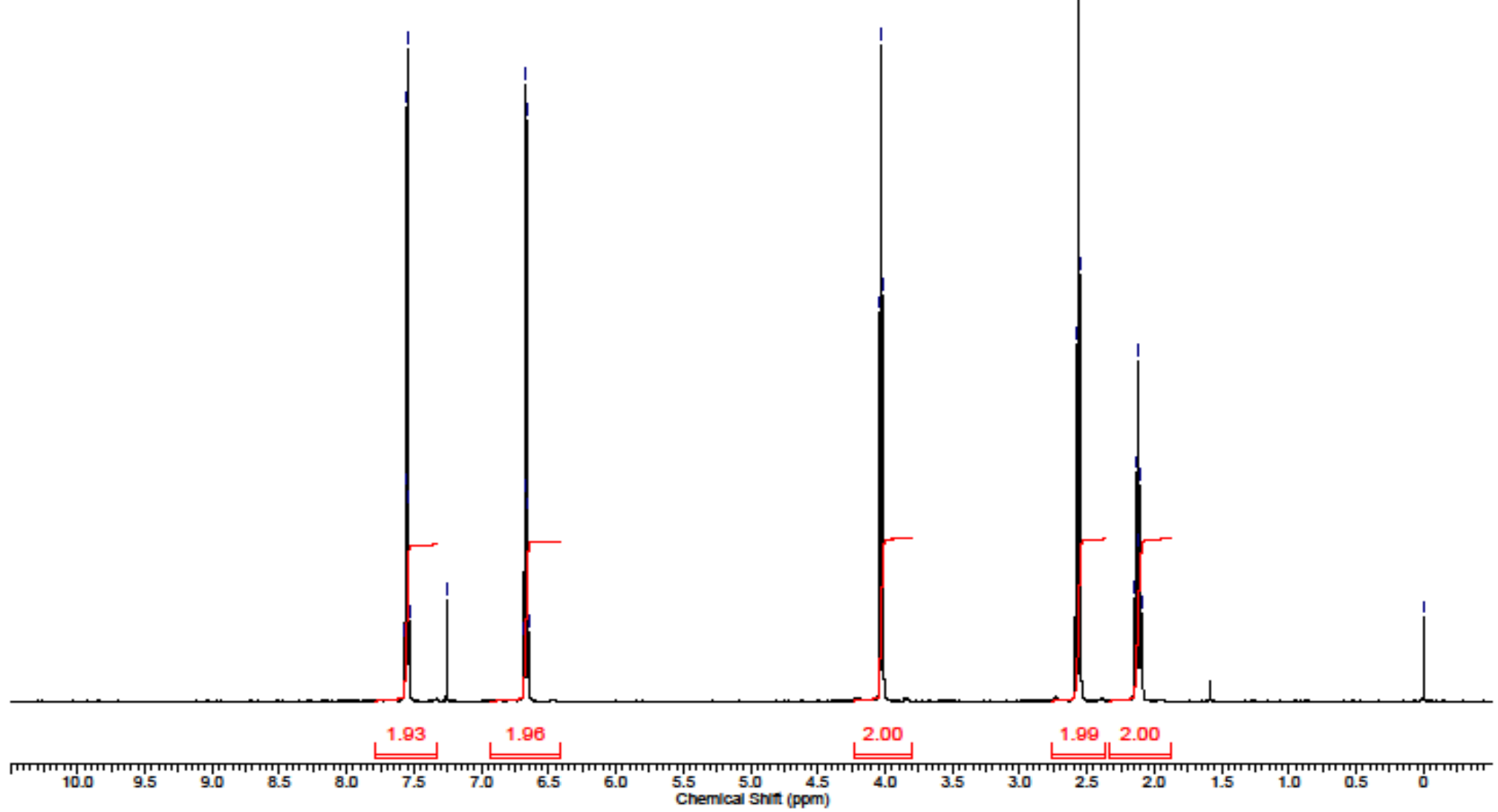


${ }^{13} \mathrm{C}\left\{{ }^{1} \mathrm{H}\right\}$ NMR spectrum of $\mathbf{1 y}$ in $\mathrm{CDCl}_{3}$ with $0.05 \% \mathrm{v} / \mathrm{v}$ MS $(100 \mathrm{MHz})$
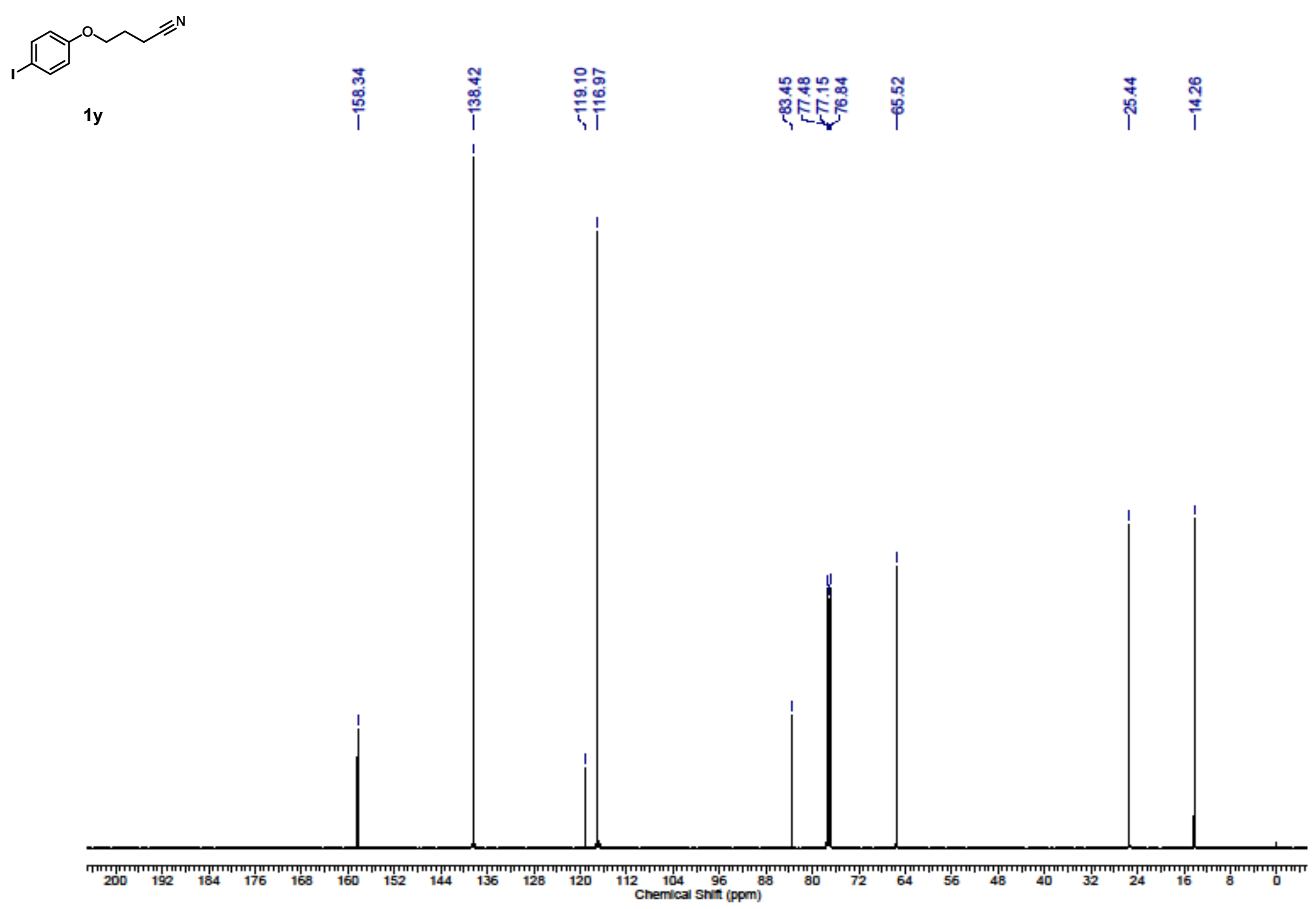

S56 
${ }^{1} \mathrm{H}$ NMR spectrum of $\mathbf{1 z}$ in $\mathrm{CDCl}_{3}$ with $0.05 \% \mathrm{v} / \mathrm{v}$ TMS $(400 \mathrm{MHz})$

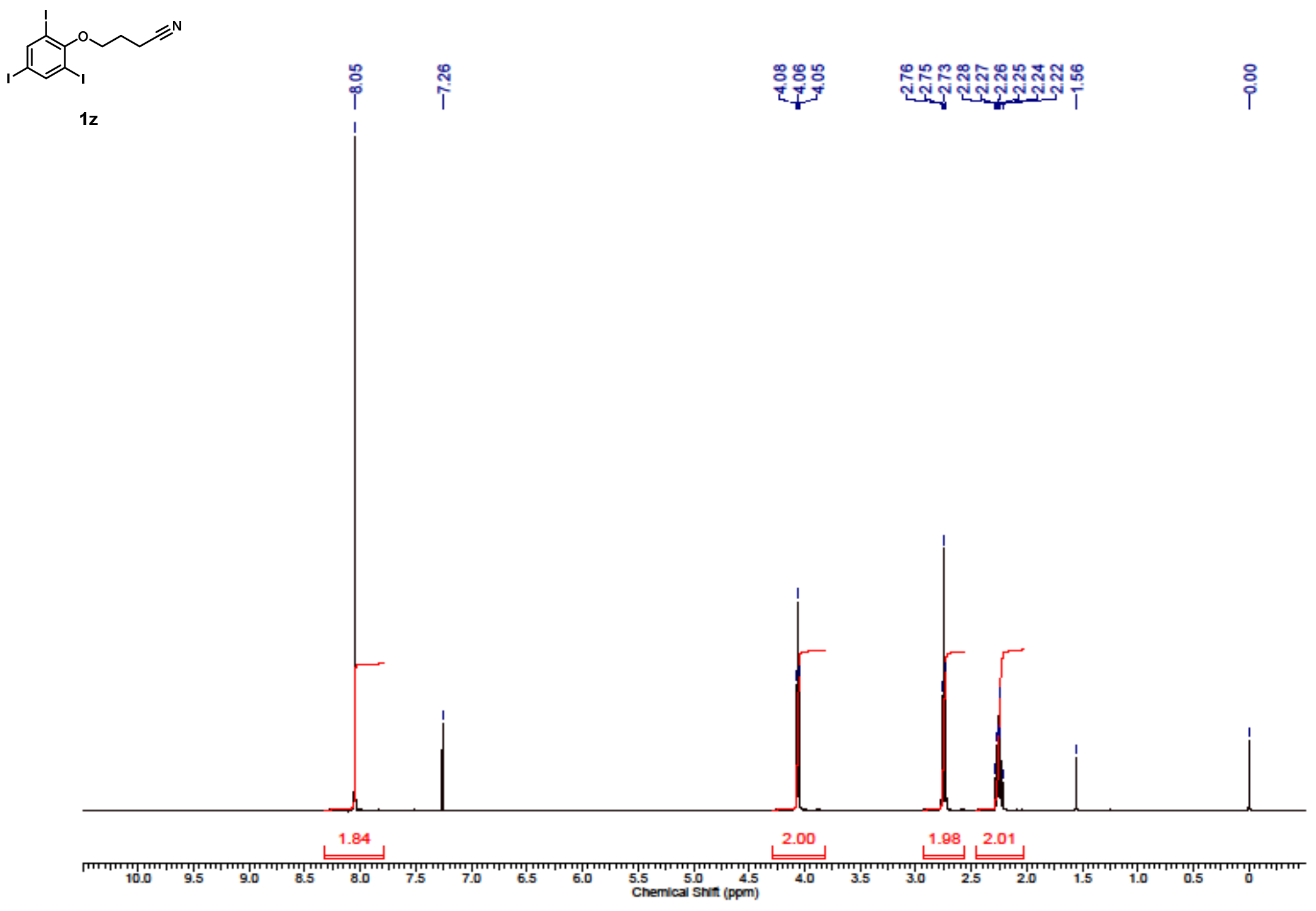


${ }^{13} \mathrm{C}\left\{{ }^{1} \mathrm{H}\right\}$ NMR spectrum of $\mathbf{1 z}$ in $\mathrm{CDCl}_{3}$ with $0.05 \% \mathrm{v} / \mathrm{v}$ TMS $(100 \mathrm{MHz})$
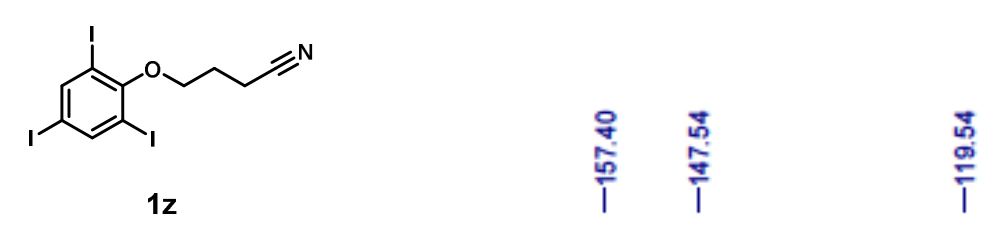

鞹
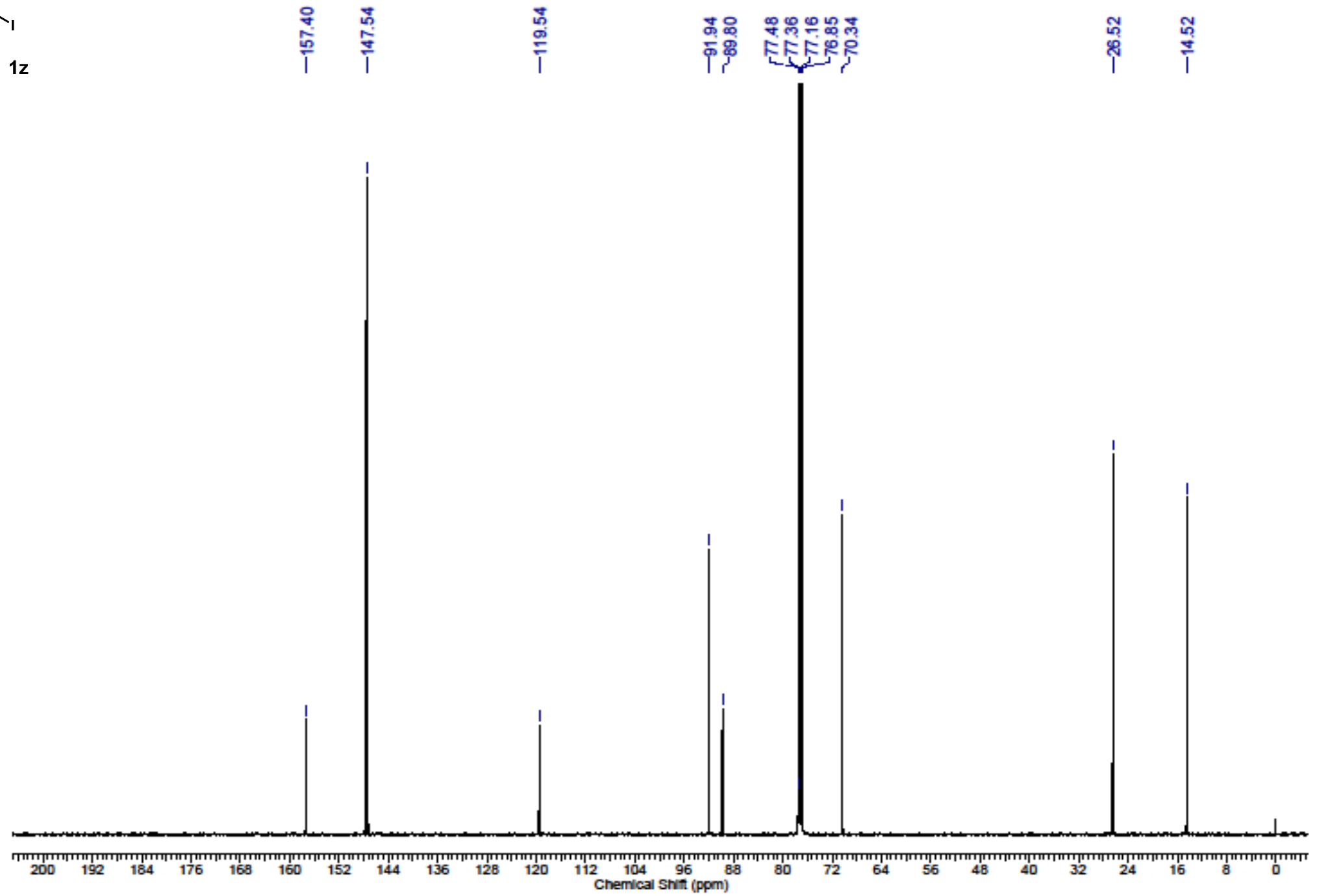

S58 
${ }^{1} \mathrm{H}$ NMR spectrum of $2 \mathrm{a}$ in $\mathrm{CDCl}_{3}$ with $0.05 \% \mathrm{v} / \mathrm{v}$ TMS $(400 \mathrm{MHz})$

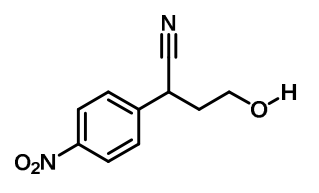

$2 a$

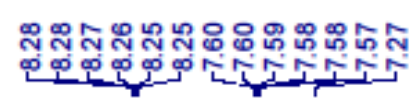

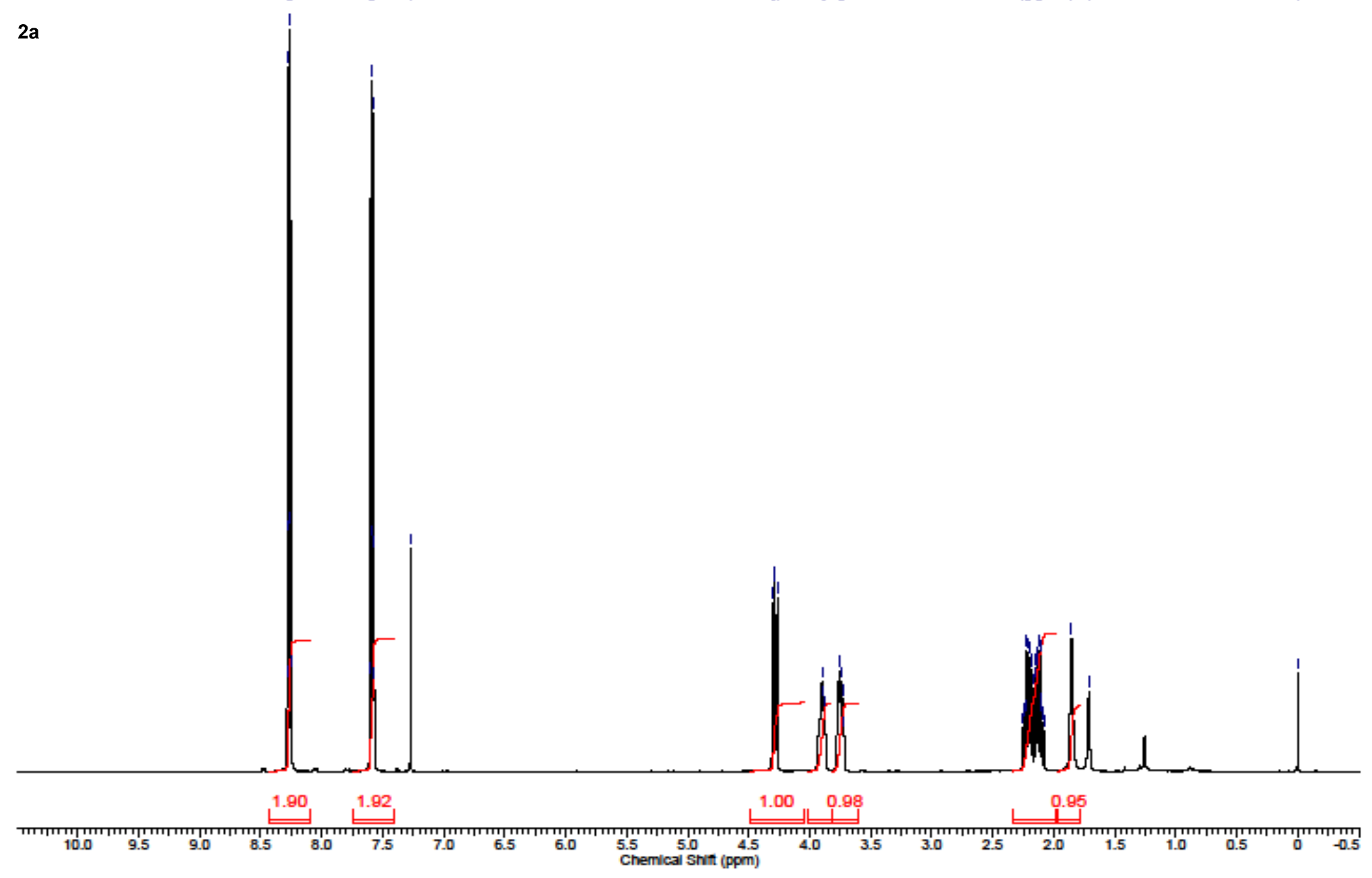

-

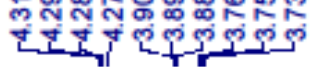

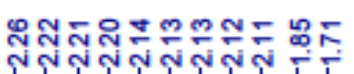

: 
${ }^{1} \mathrm{H}$ NMR spectrum of $\mathbf{2 a}$ in $\left(\mathrm{CD}_{3}\right)_{2}$ SO with $0.05 \% \mathrm{v} / \mathrm{v}$ TMS $(400 \mathrm{MHz})$

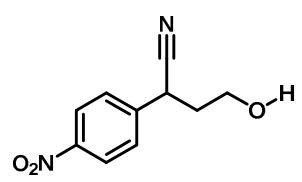

สิศกิ

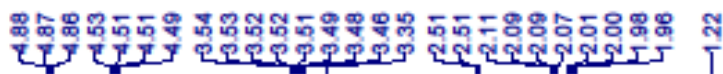

2a

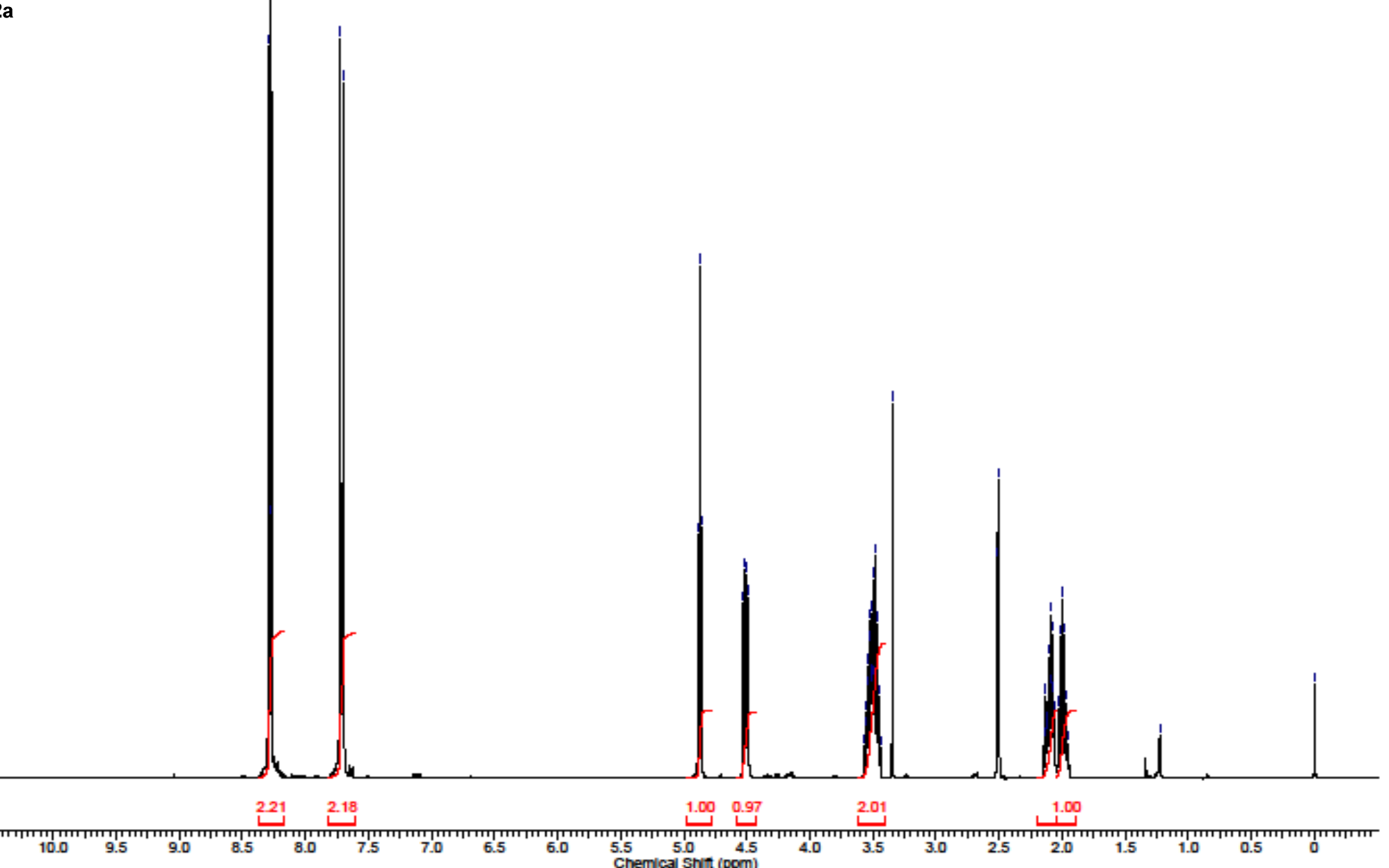


${ }^{13} \mathrm{C}\left\{{ }^{1} \mathrm{H}\right\}$ NMR spectrum of $2 \mathrm{a}$ in $\mathrm{CDCl}_{3}$ with $0.05 \% \mathrm{v} / \mathrm{v}$ TMS (100 MHz)

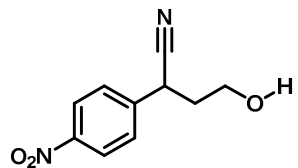

$\mathbf{2 a}$
充紊

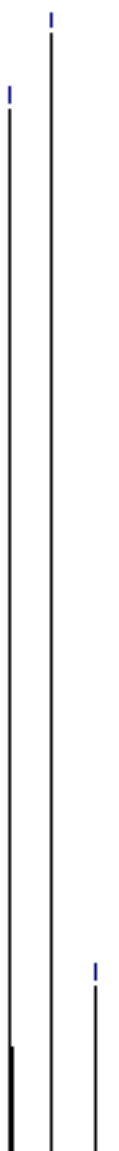

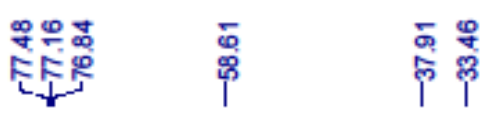
|||||| $\mid$ 
${ }^{13} \mathrm{C}\left\{{ }^{1} \mathrm{H}\right\}$ NMR spectrum of $\mathbf{2 a}$ in $\left(\mathrm{CD}_{3}\right)_{2} \underline{S O}$ with $0.05 \% \mathrm{v} / \mathrm{v}$ TMS $(100 \mathrm{MHz})$

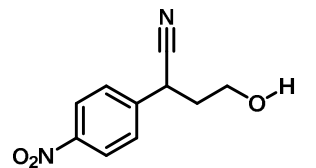

$\mathbf{2 a}$

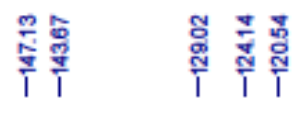

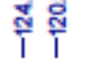

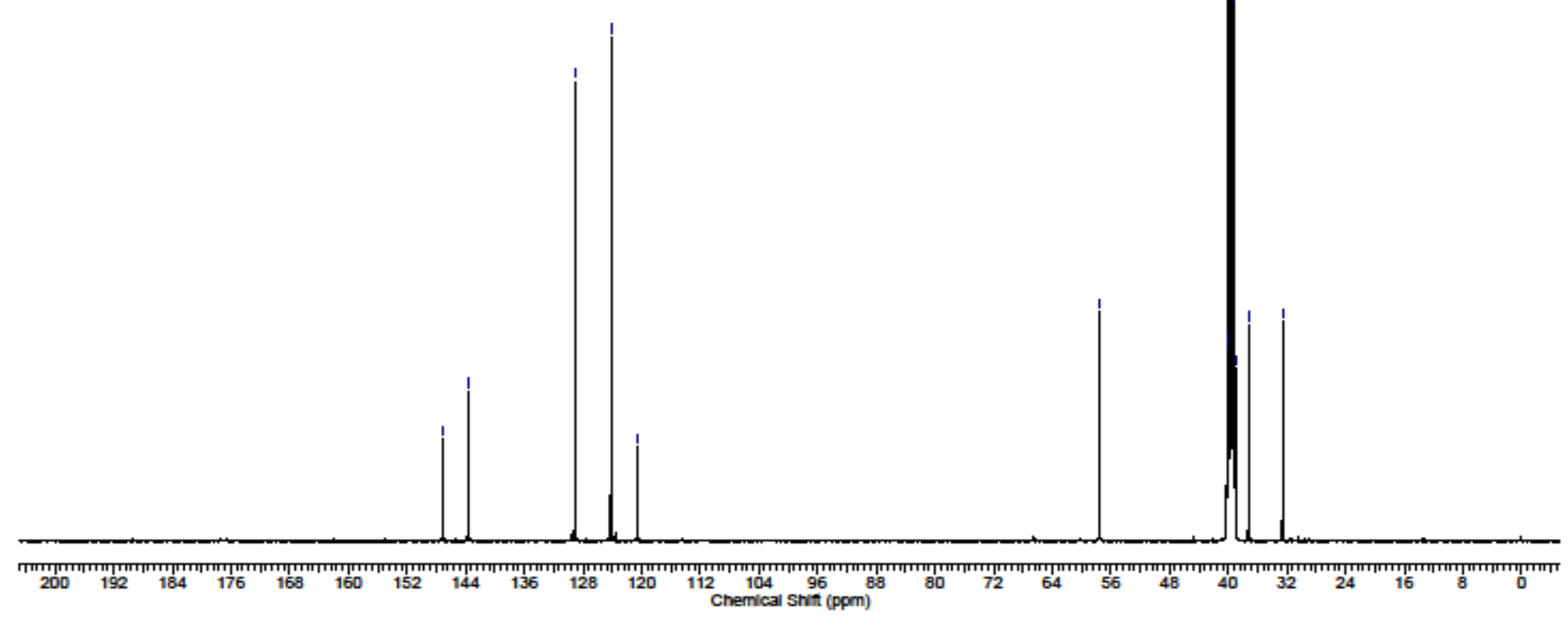


${ }^{1} \mathrm{H}$ NMR spectrum of $\mathbf{2 c}$ in $\mathrm{CDCl}_{3}$ with $0.05 \% \mathrm{v} / \mathrm{v}$ TMS $(400 \mathrm{MHz})$

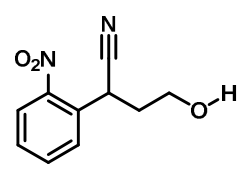

2c
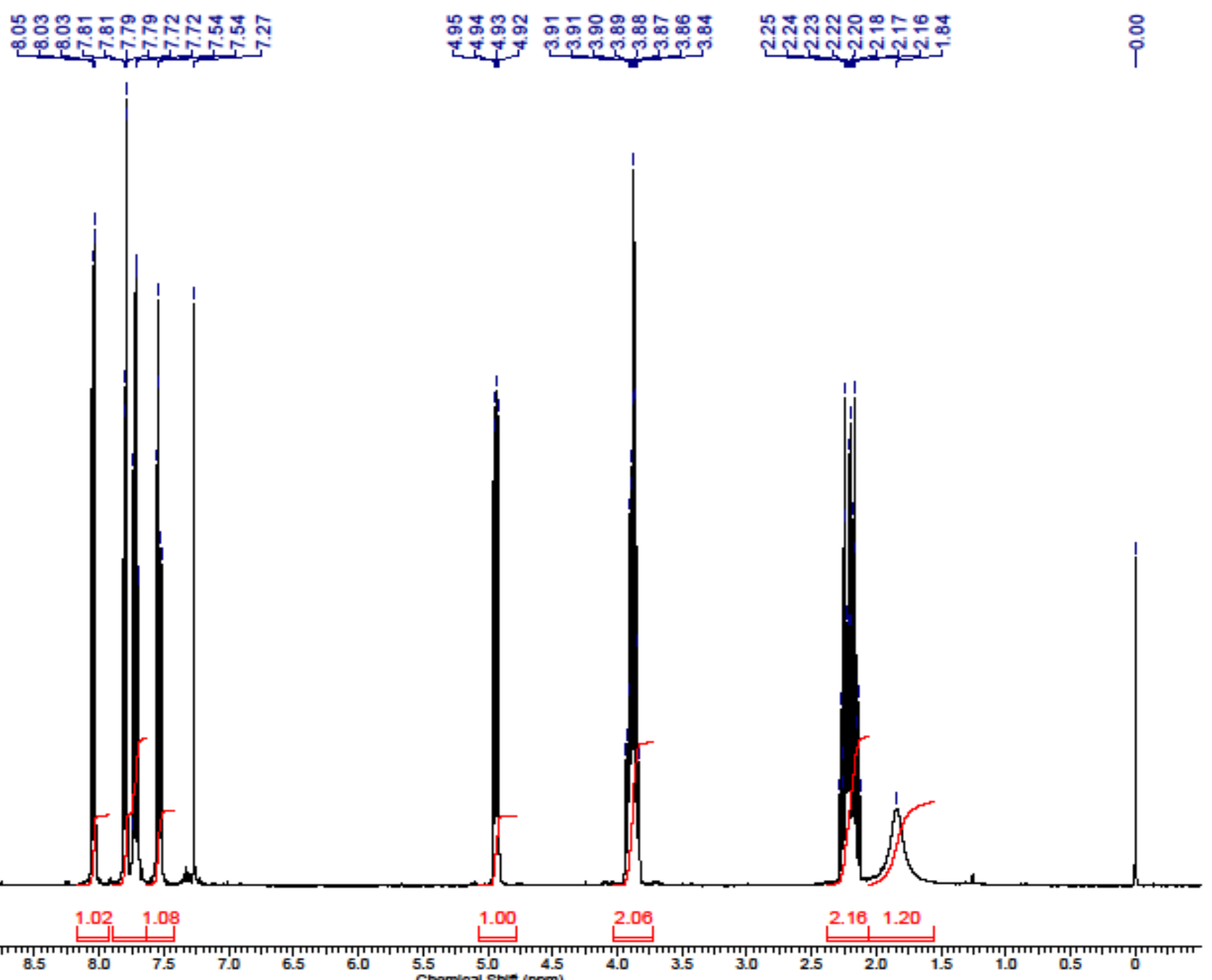
${ }^{13} \mathrm{C}\left\{{ }^{1} \mathrm{H}\right\}$ NMR spectrum of $2 \mathrm{c}$ in $\mathrm{CDCl}_{3}$ with $0.05 \% \mathrm{v} / \mathrm{v}$ TMS (100 MHz)

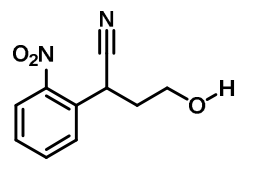

2c

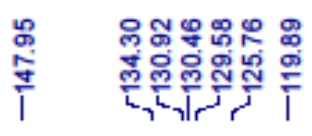

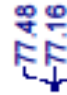

눈

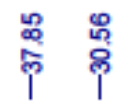

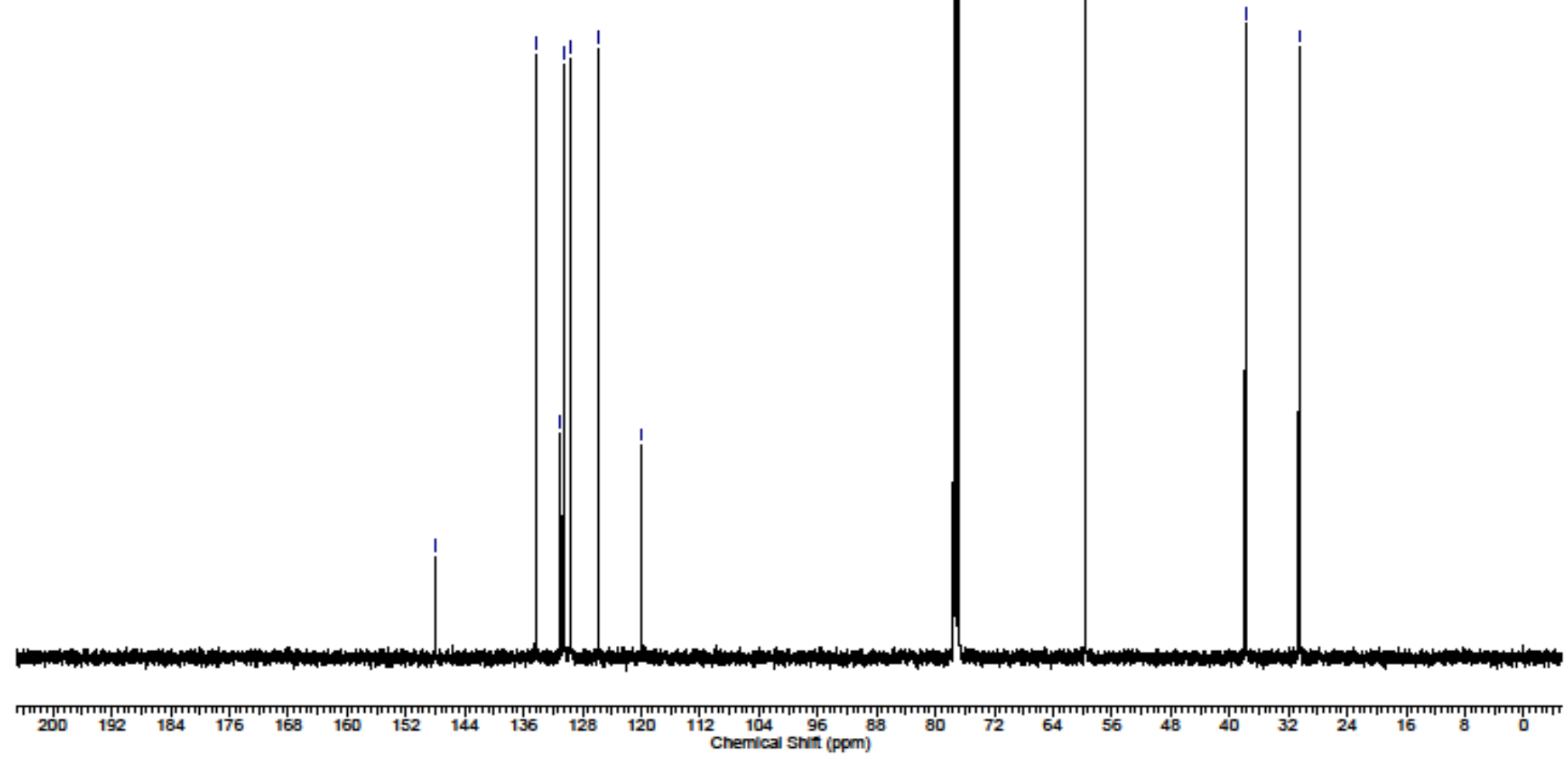


${ }^{1} \mathrm{H}$ NMR spectrum of $\mathbf{2 d}$ in $\mathrm{CDCl}_{3}$ with $0.05 \% \mathrm{v} / \mathrm{v}$ TMS $(400 \mathrm{MHz})$

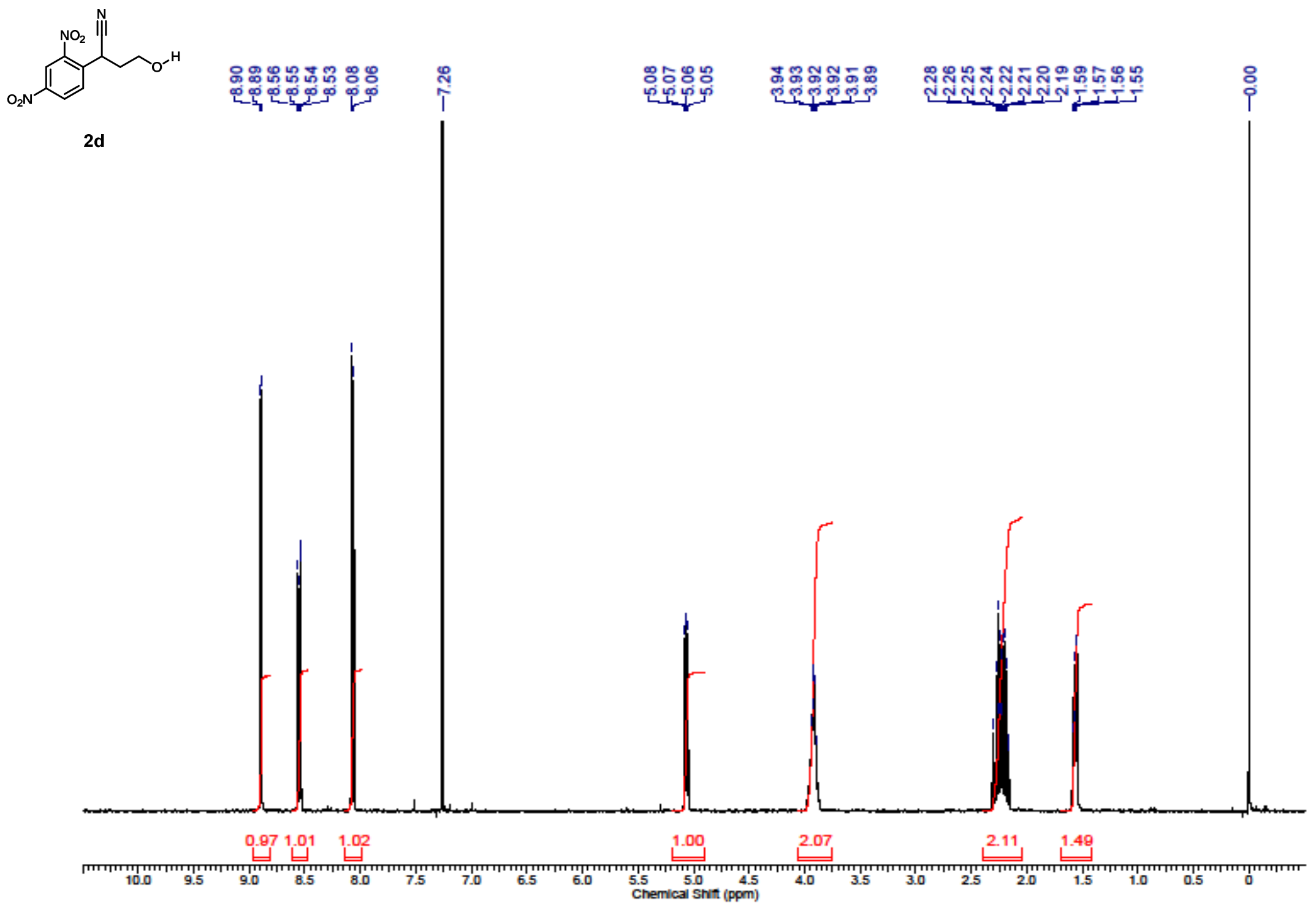


${ }^{13} \mathrm{C}\left\{{ }^{1} \mathrm{H}\right\}$ NMR spectrum of $2 \mathrm{~d}$ in $\mathrm{CDCl}_{3}$ with $0.05 \% \mathrm{v} / \mathrm{v}$ MS $(100 \mathrm{MHz})$<smiles>N#CC(CCO)c1ccc([N+](=O)[O-])cc1[N+](=O)[O-]</smiles>

Id
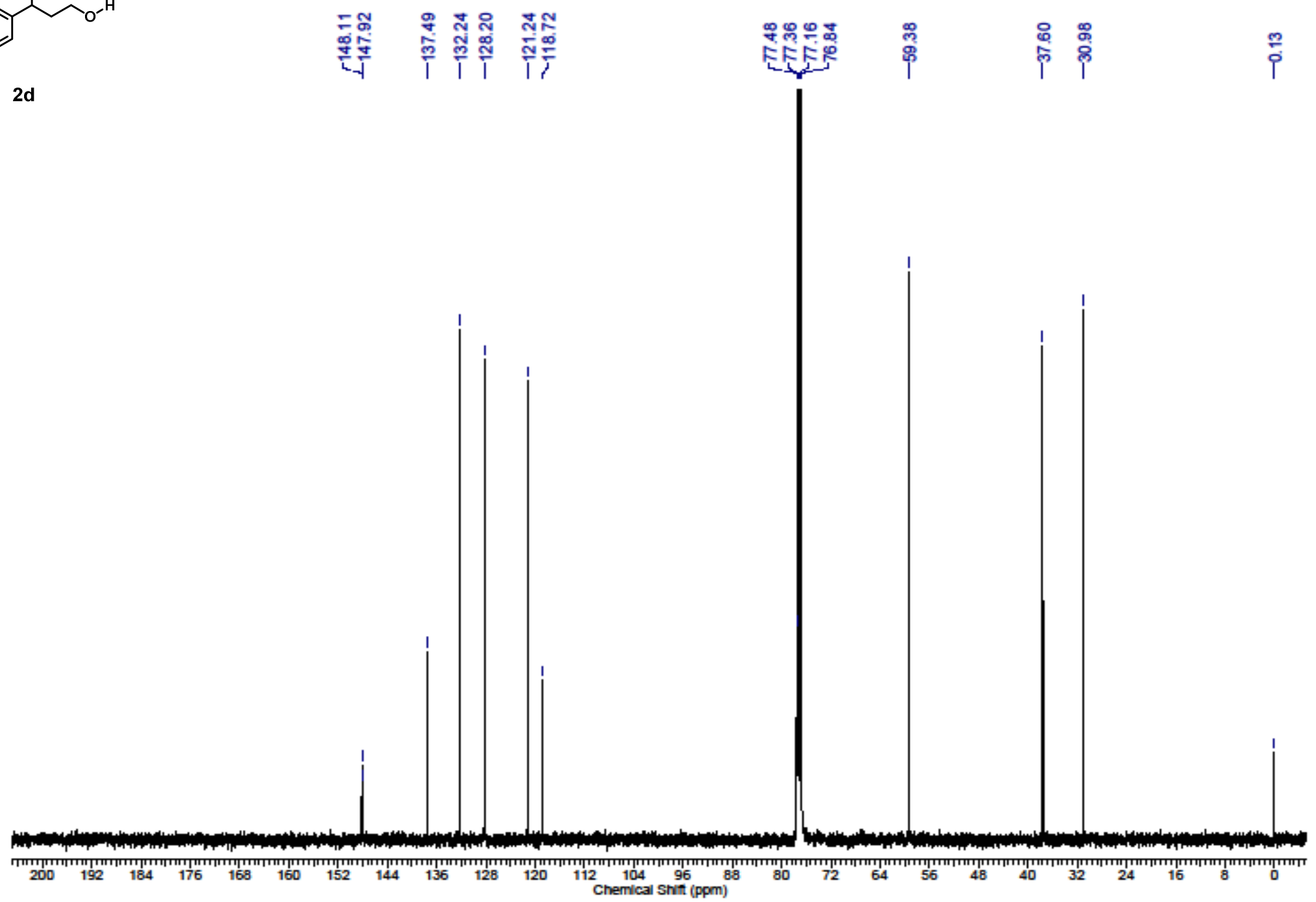

S66 
${ }^{1} \mathrm{H}$ NMR spectrum of $2 \mathbf{e}$ in $\mathrm{CDCl}_{3}$ with $0.05 \% \mathrm{v} / \mathrm{v}$ TMS $(400 \mathrm{MHz})$

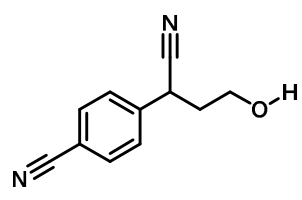

$2 \mathrm{e}$

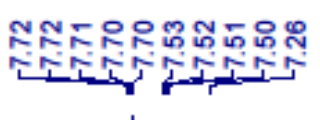

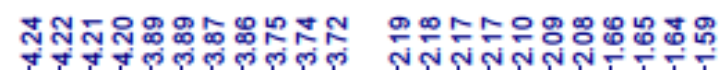

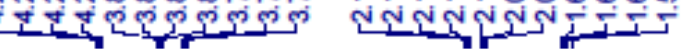

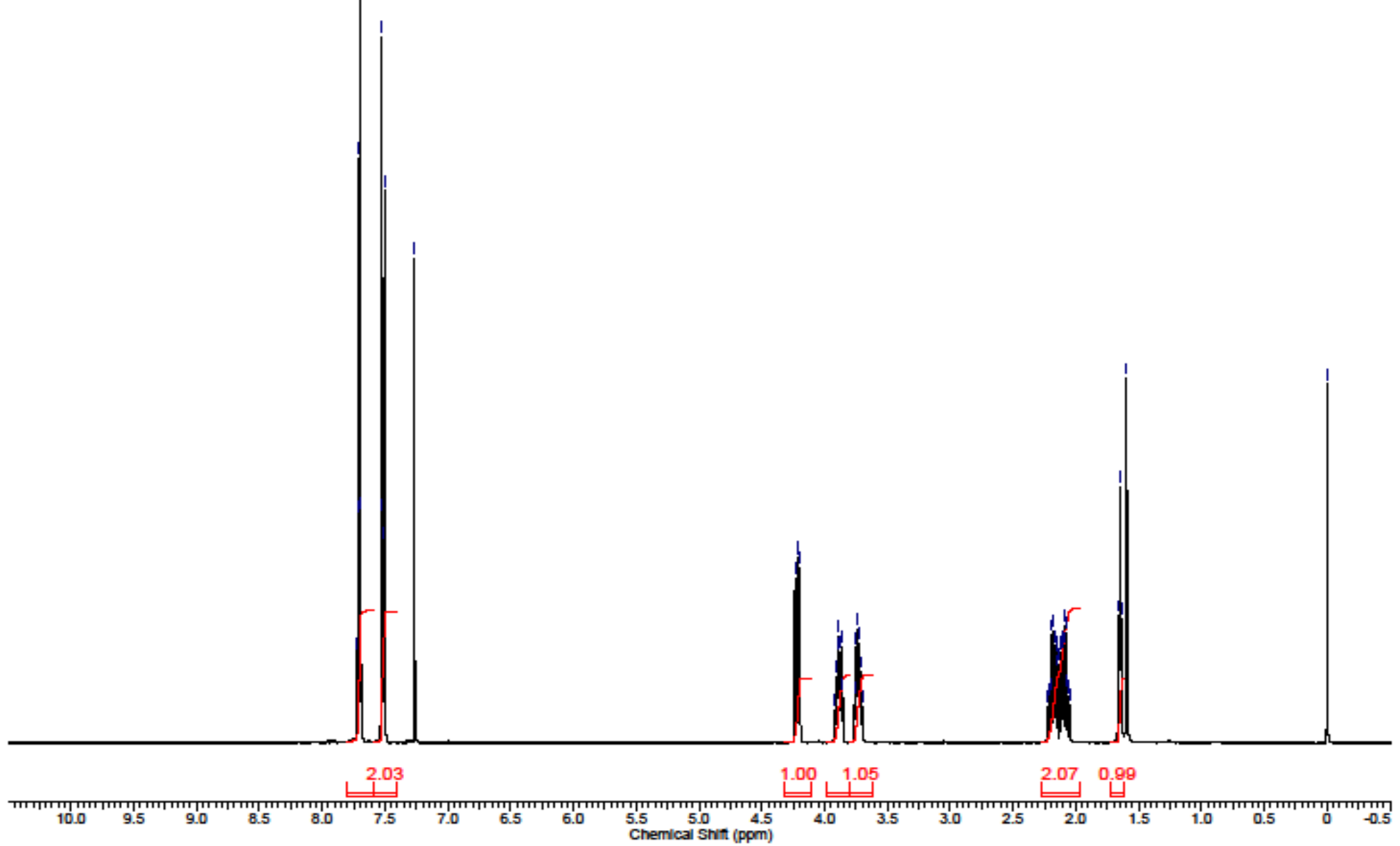


${ }^{13} \mathrm{C}\left\{{ }^{1} \mathrm{H}\right\}$ NMR spectrum of $2 \mathrm{e}$ in $\mathrm{CDCl}_{3}$ with $0.05 \% \mathrm{v} / \mathrm{v}$ TMS (100 MHz)

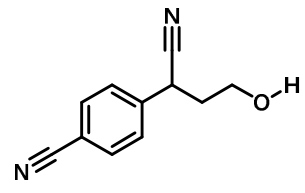

$2 \mathrm{e}$ i

怘

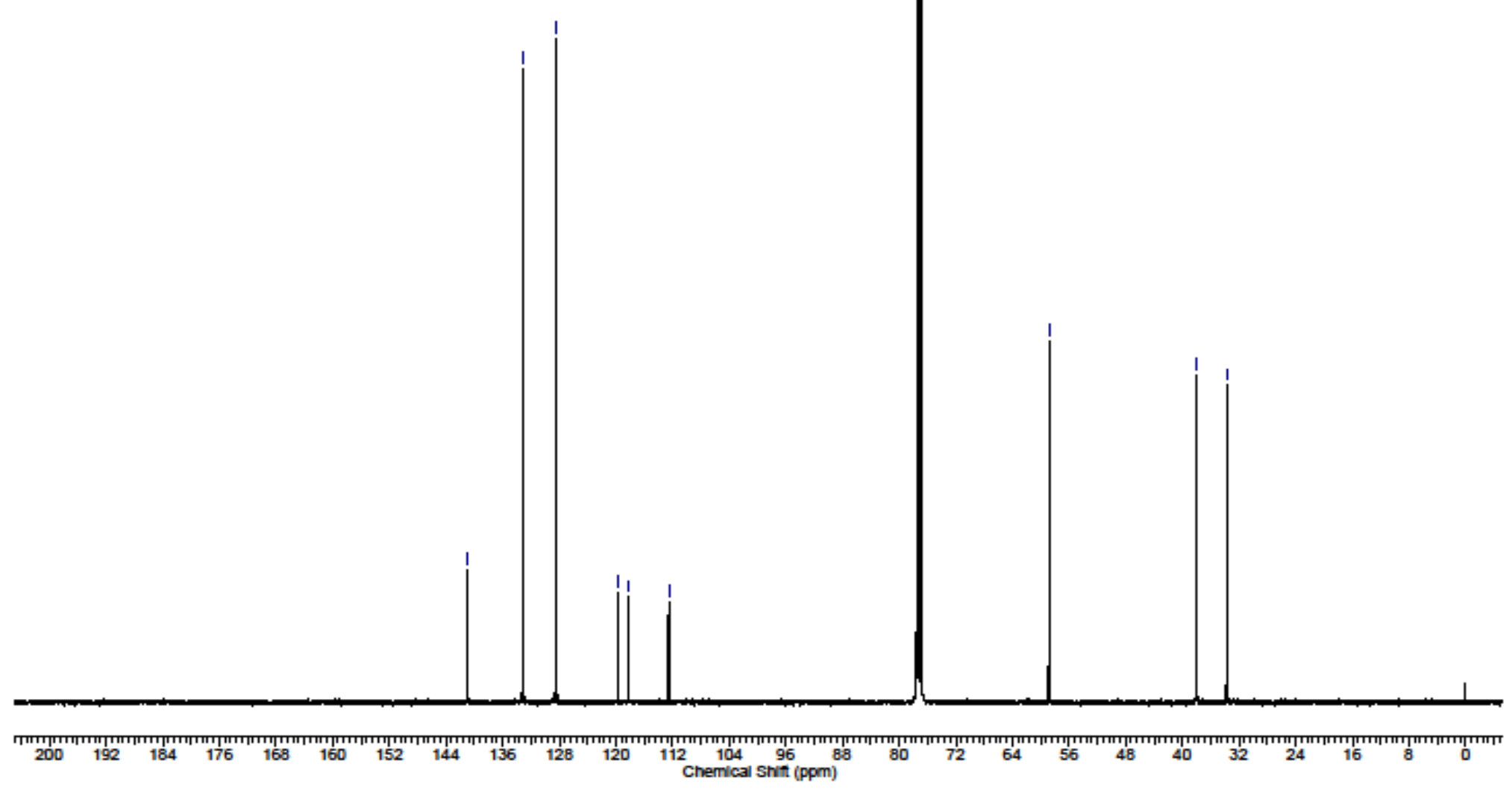


$\underline{{ }^{1} \mathrm{H} N M R \text { spectrum of } \mathbf{2 f} \text { in } \mathrm{CDCl}_{3} \text { with } 0.05 \% \mathrm{v} / \mathrm{v} \text { TMS (400 MHz) }}$

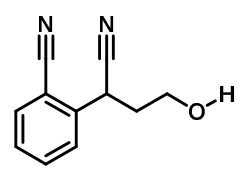

2f
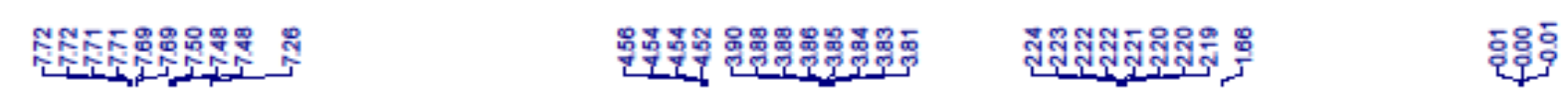

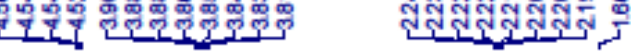

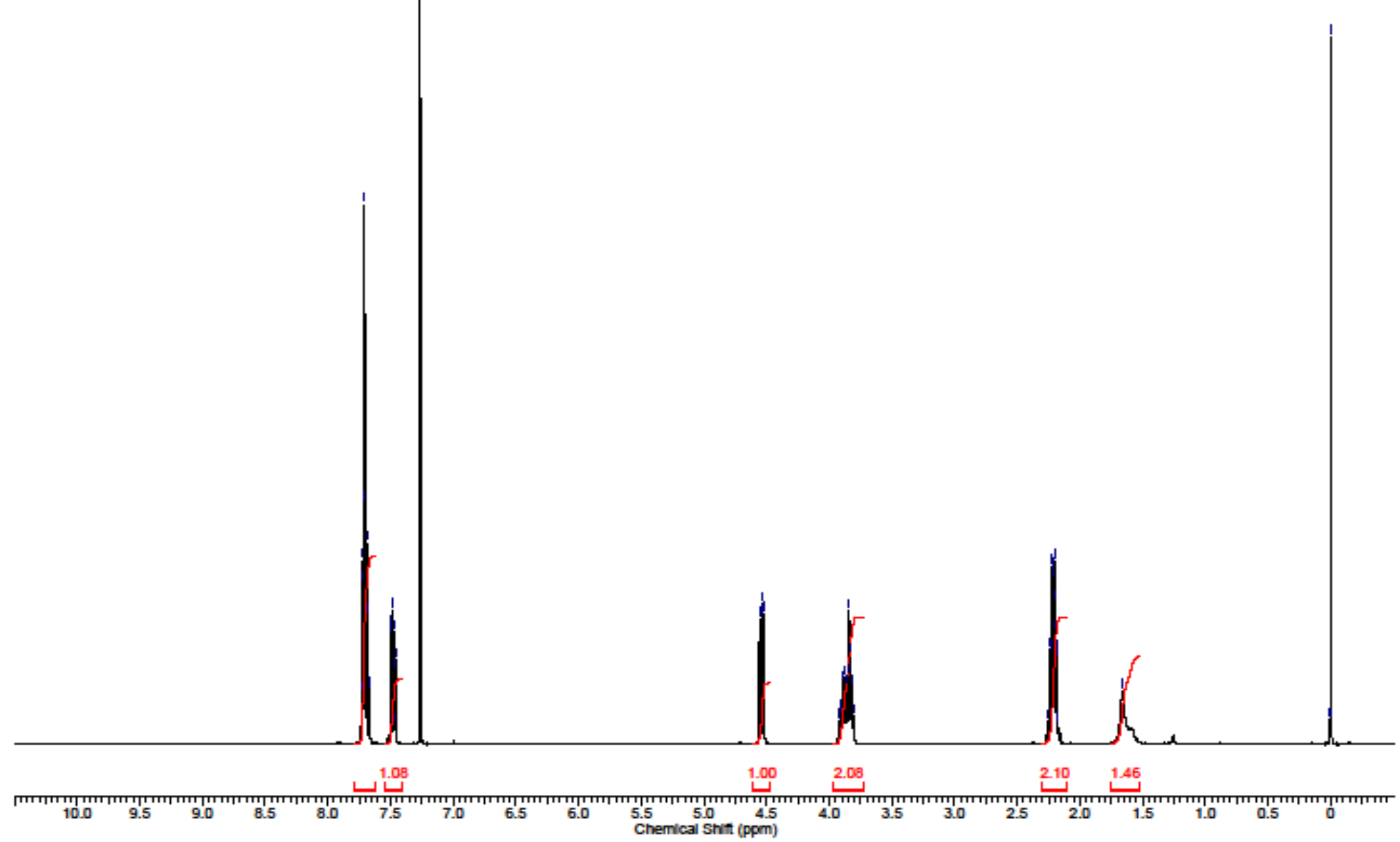


${ }^{13} \mathrm{C}\left\{{ }^{1} \mathrm{H}\right\}$ NMR spectrum of $2 \mathrm{f}$ in $\mathrm{CDCl}_{3}$ with $0.05 \% \mathrm{v} / \mathrm{v}$ TMS (100 MHz)

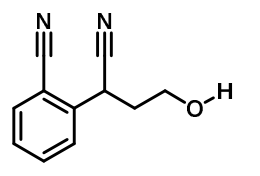

$2 f$

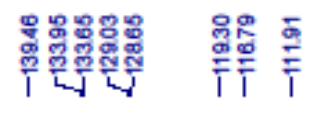

क्षाप का

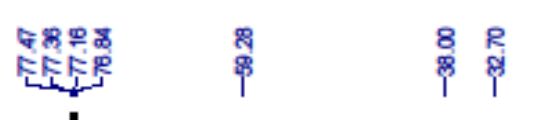

$\frac{1}{p}$

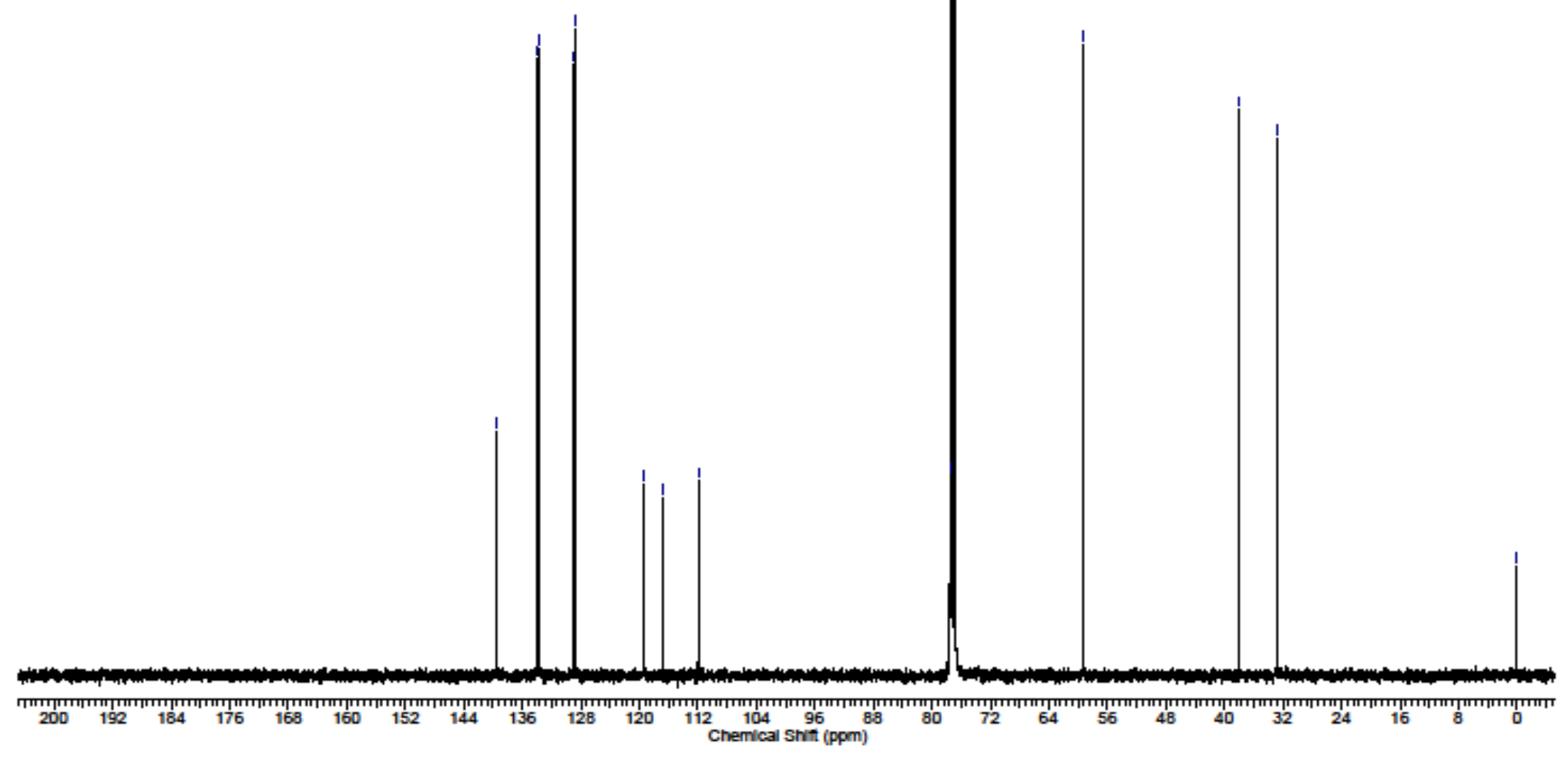


${ }^{1} \mathrm{H}$ NMR spectrum of $\mathbf{2 g}$ in $\mathrm{CDCl}_{3}$ with $0.05 \% \mathrm{v} / \mathrm{v}$ TMS (400 MHz)

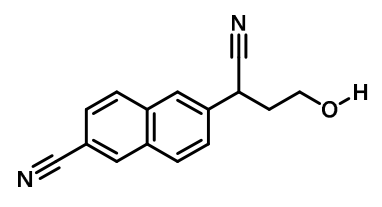

2g
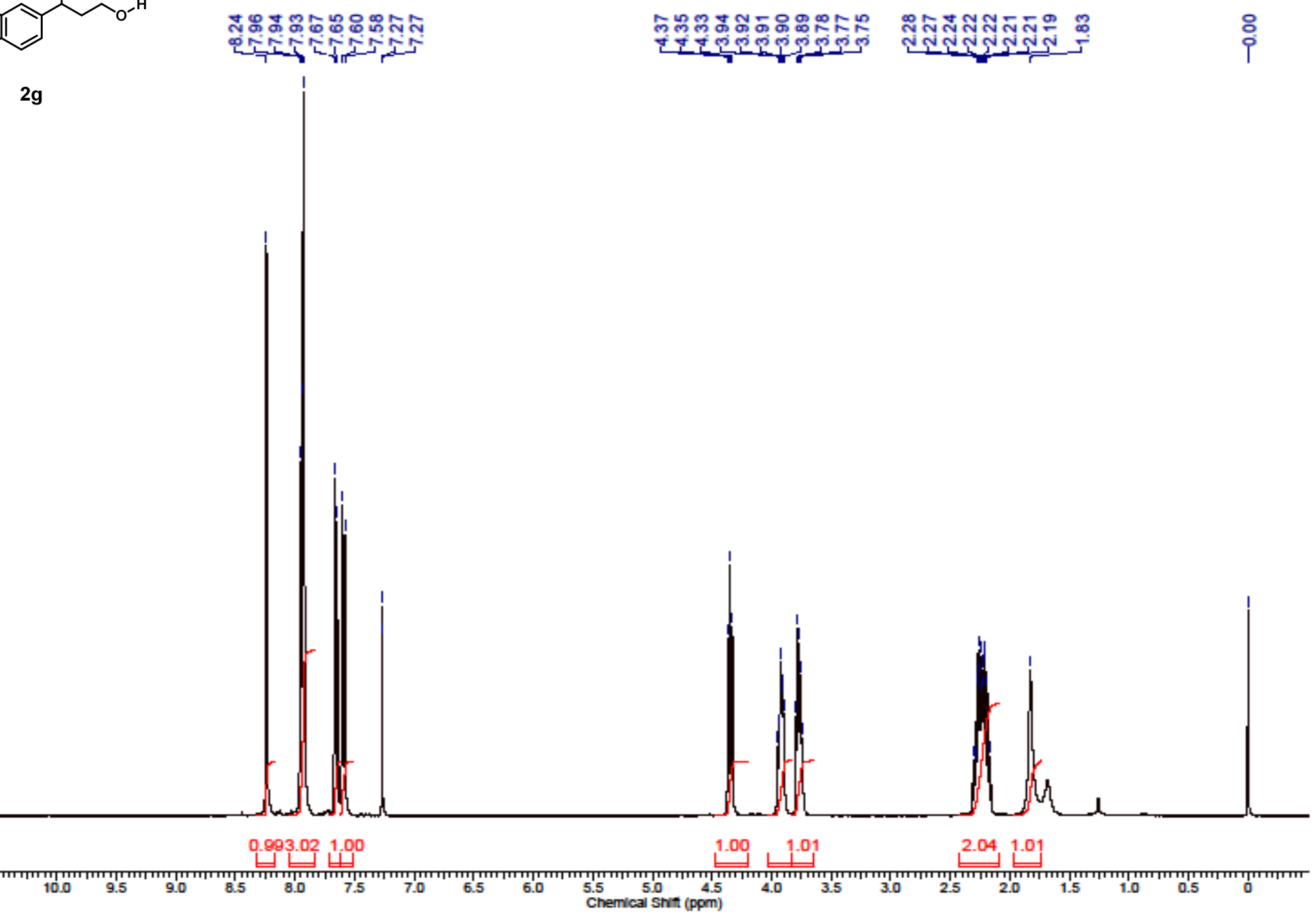


$$
\bar{I}
$$


$\underline{{ }^{1} \mathrm{H} \text { NMR spectrum of } \mathbf{2} \mathbf{j} \text { in } \mathrm{CDCl}_{3} \text { with } 0.05 \% \mathrm{v} / \mathrm{v} \text { TMS (400 MHz) }}$

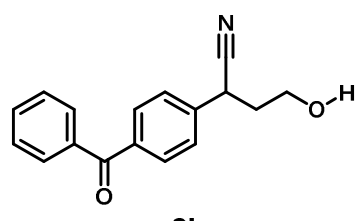

2j

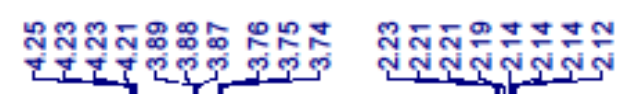

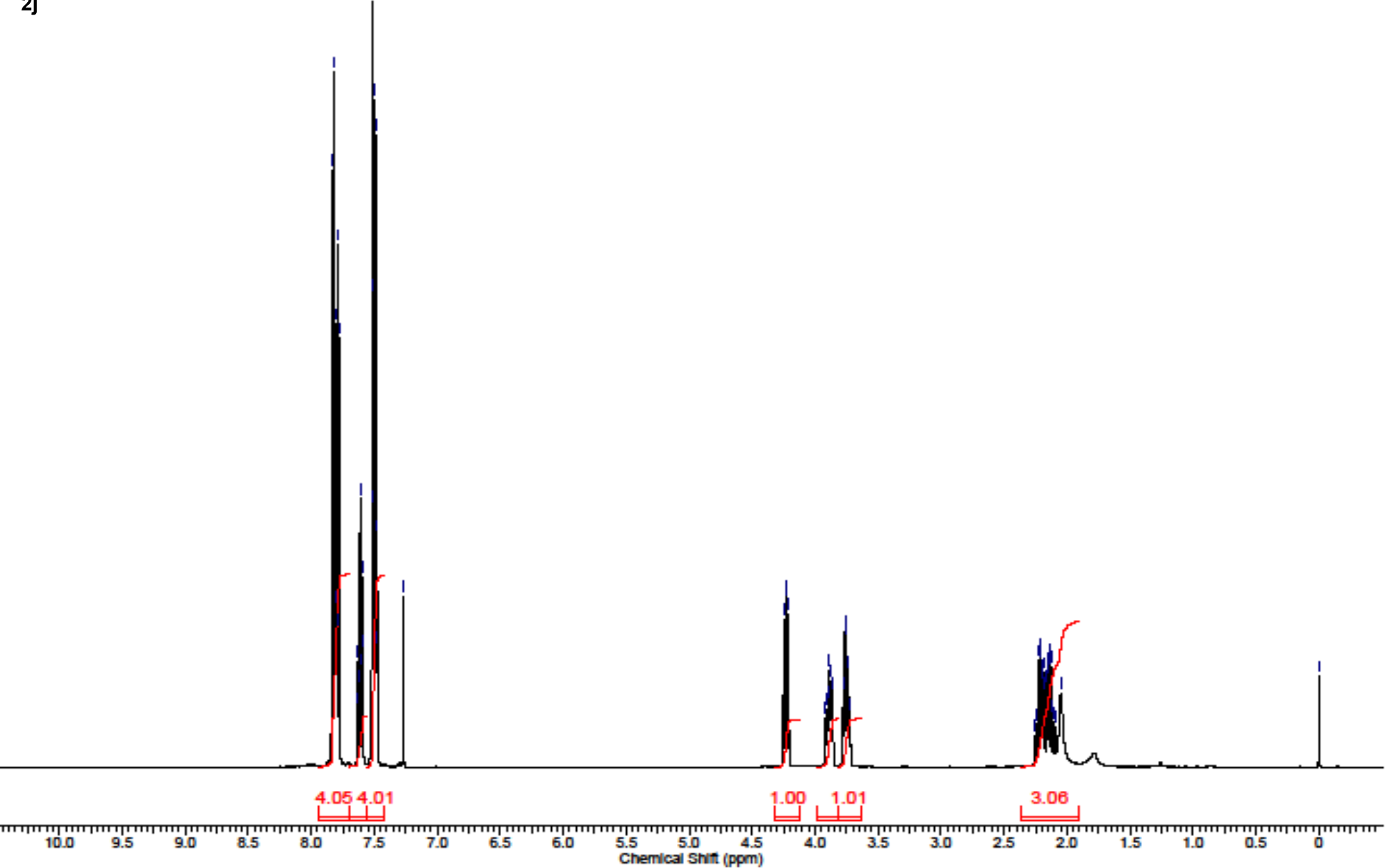


${ }^{13} \mathrm{C}\left\{{ }^{1} \mathrm{H}\right\}$ NMR spectrum of $2 \mathbf{j}$ in $\mathrm{CDCl}_{3}$ with $0.05 \% \mathrm{v} / \mathrm{v}$ TMS (100 MHz)
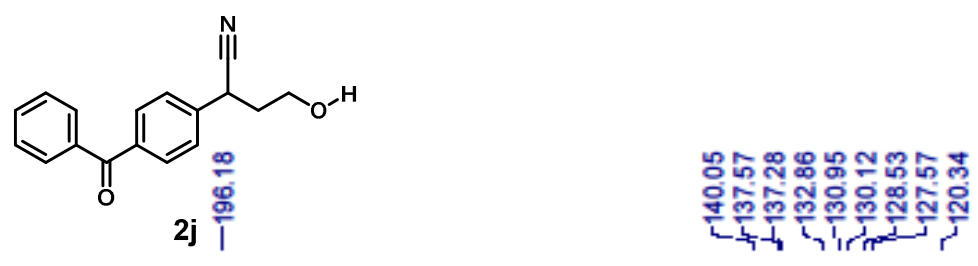

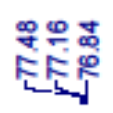

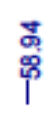

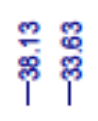

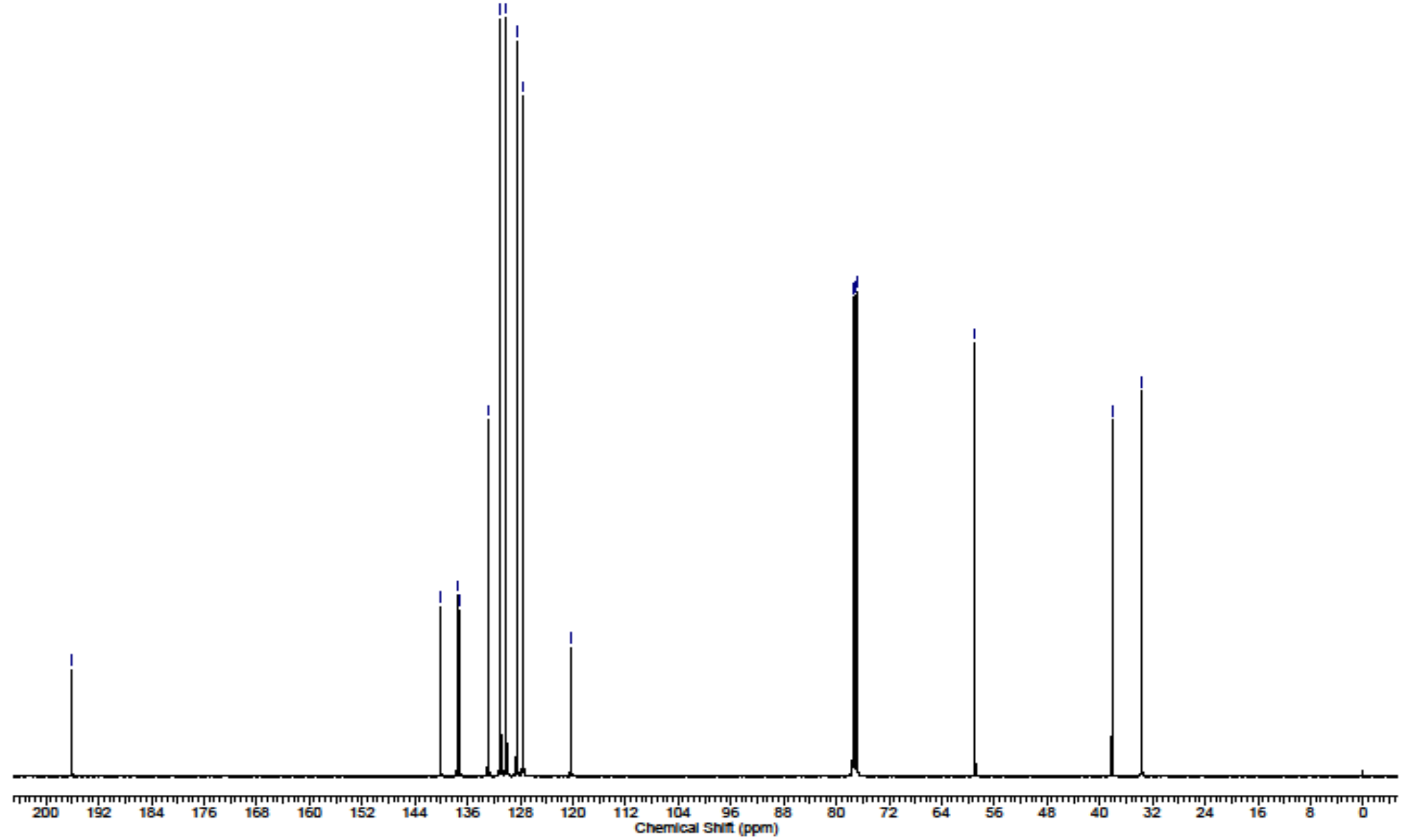

S74 
${ }^{1} \mathrm{H}$ NMR spectrum of $2 \mathbf{r}$ in $\mathrm{CDCl}_{3}$ with $0.05 \%$ v/v TMS (400 MHz)

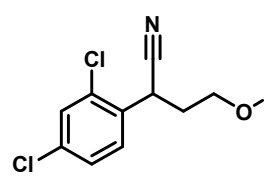

$2 r$
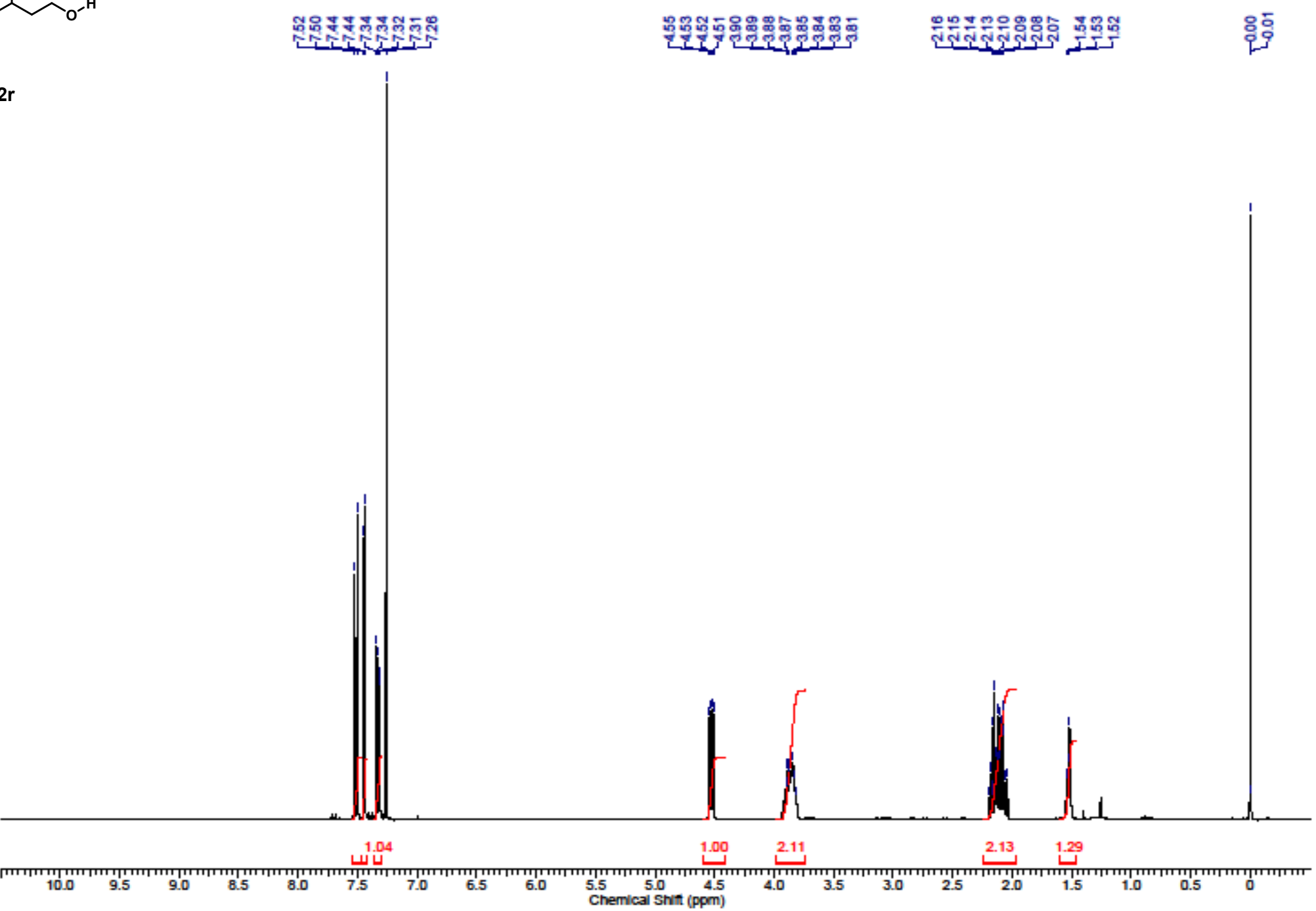
${ }^{13} \mathrm{C}\left\{{ }^{1} \mathrm{H}\right\}$ NMR spectrum of $2 \mathbf{r}$ in $\mathrm{CDCl}_{3}$ with $0.05 \% \mathrm{v} / \mathrm{v}$ TMS (100 MHz)

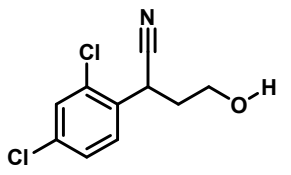

$2 r$

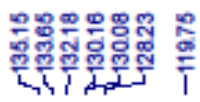

눈

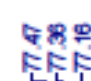

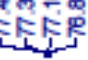

I

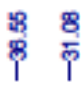

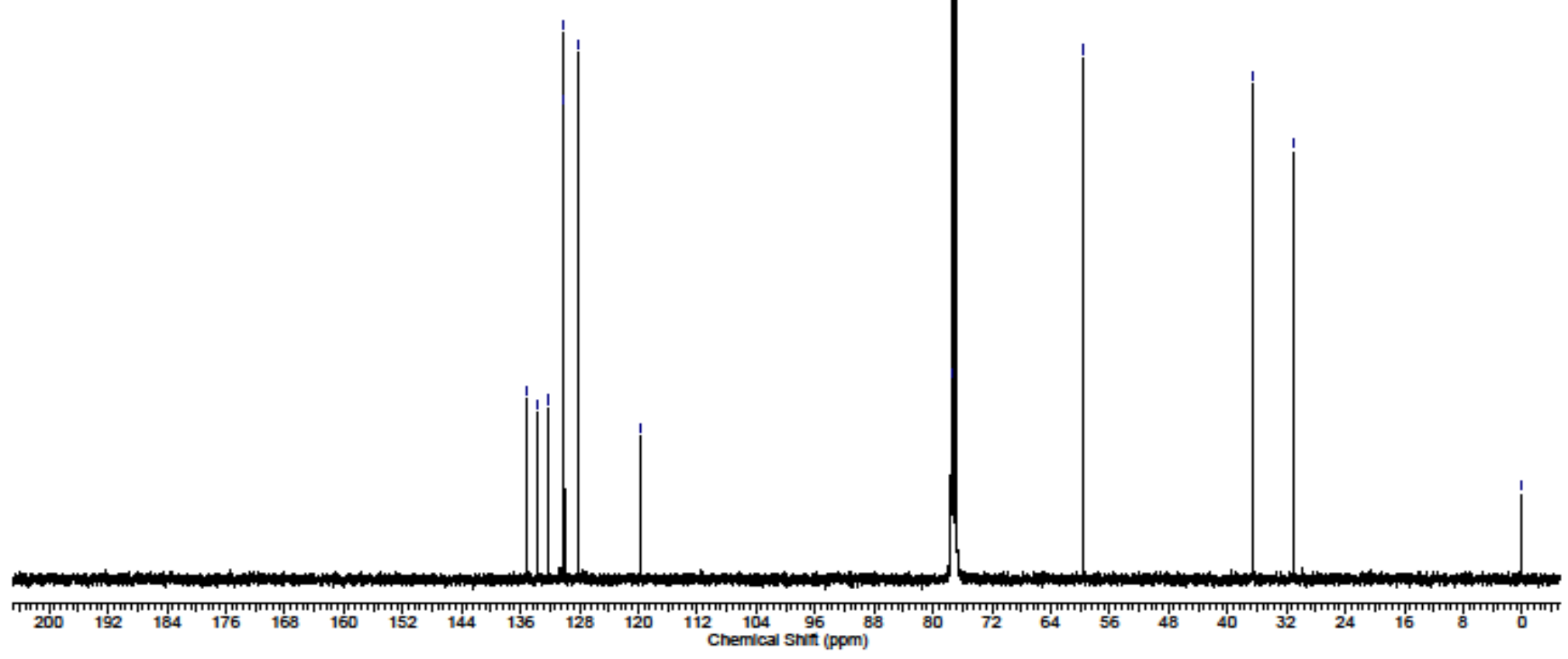


${ }^{1} \mathrm{H}$ NMR spectrum of $2 \mathrm{~s}$ in $\mathrm{CDCl}_{3}$ with $0.05 \% \mathrm{v} / \mathrm{v}$ TMS (400 MHz)

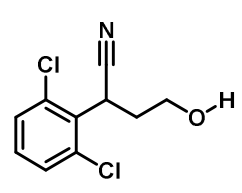

๓ะ⿻ำ

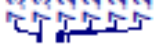

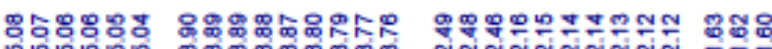

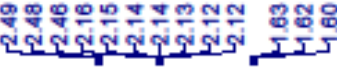

2s

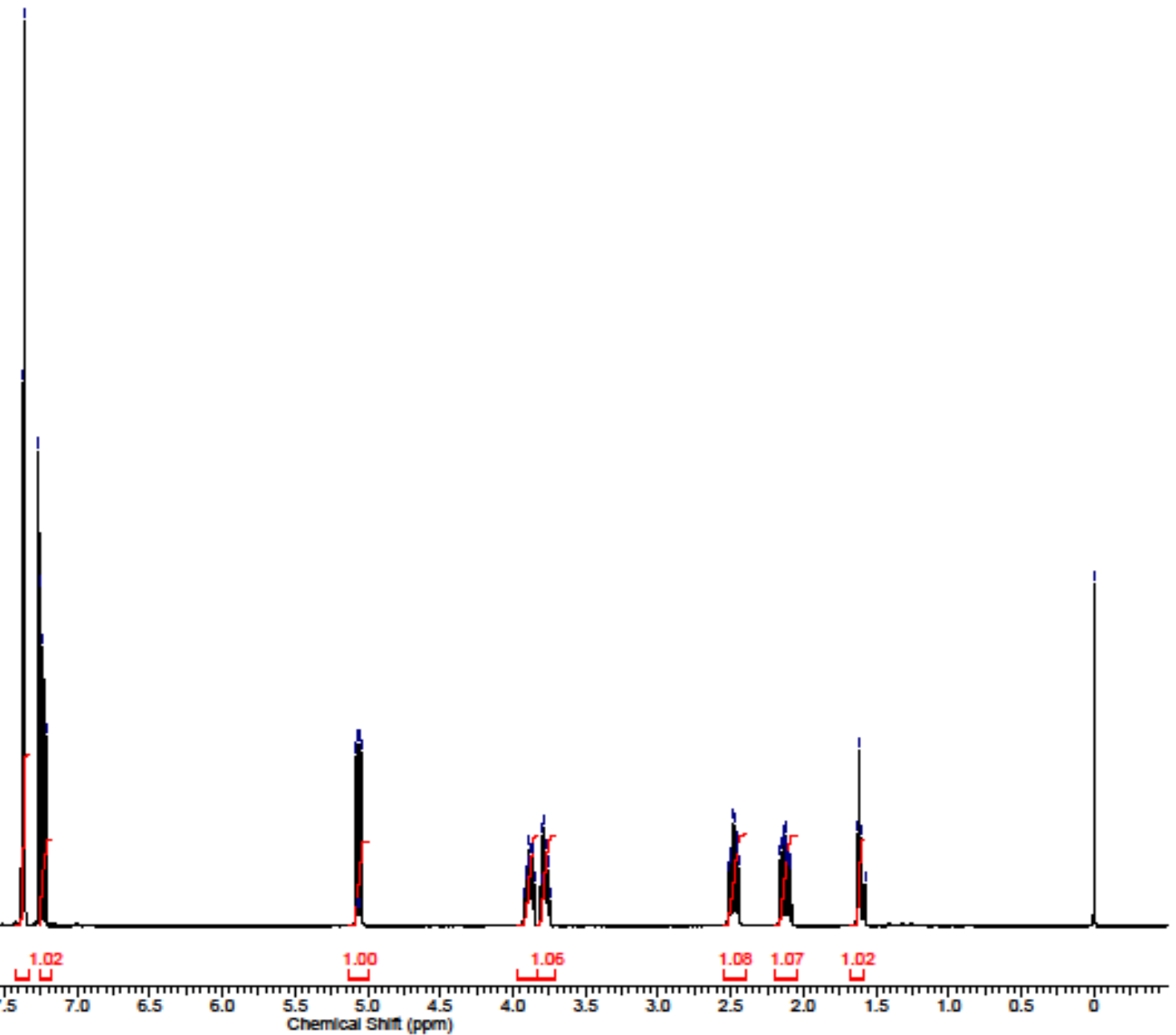




$$
\text { Till }
$$


${ }^{1} \mathrm{H}$ NMR spectrum of $\mathbf{2 t}$ in $\mathrm{CDCl}_{3}$ with $0.05 \% \mathrm{v} / \mathrm{v}$ TMS $(400 \mathrm{MHz})$
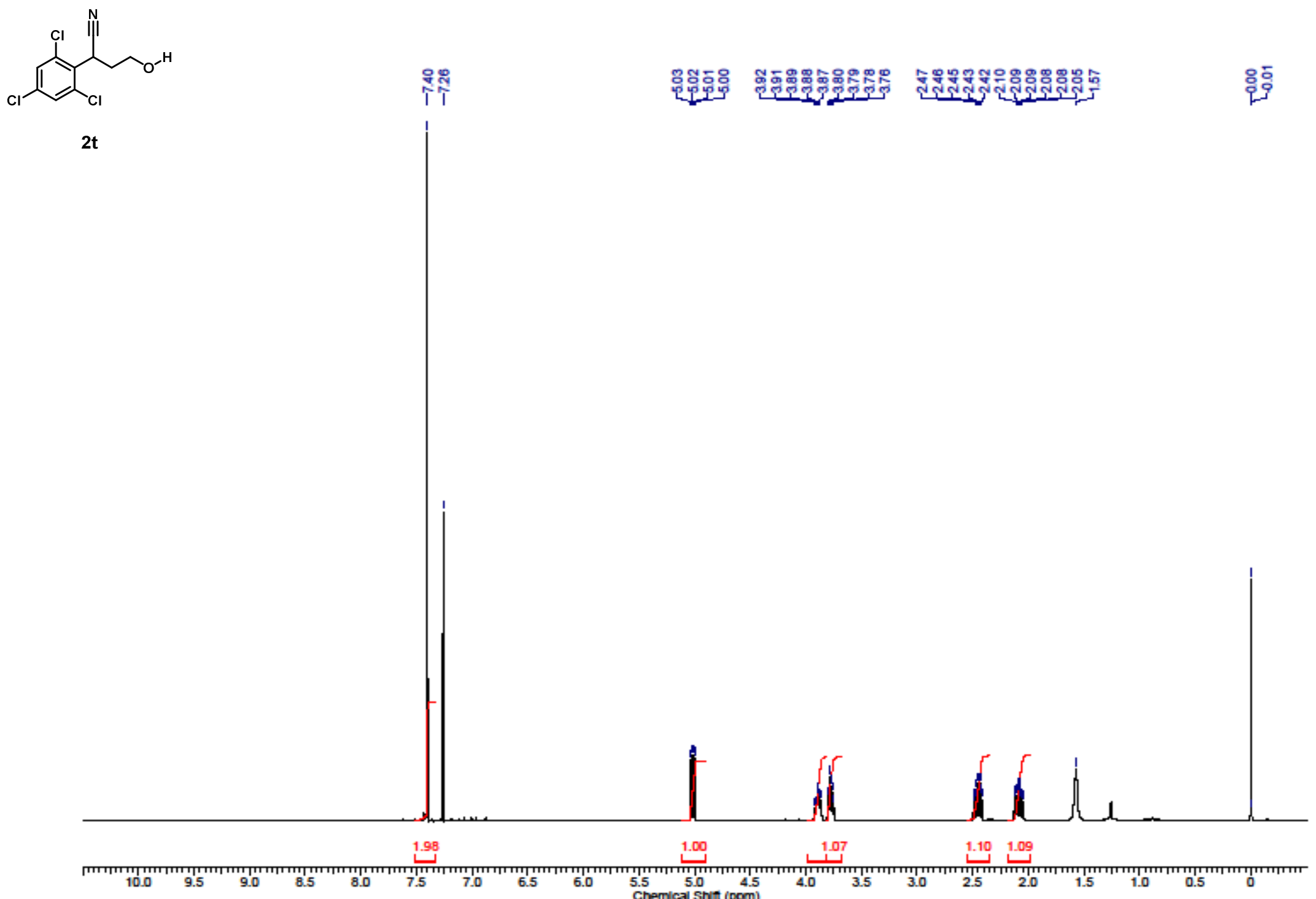
${ }^{13} \mathrm{C}\left\{{ }^{1} \mathrm{H}\right\}$ NMR spectrum of $\mathbf{2 t}$ in $\mathrm{CDCl}_{3}$ with $0.05 \% \mathrm{v} / \mathrm{v}$ TMS (100 MHz)

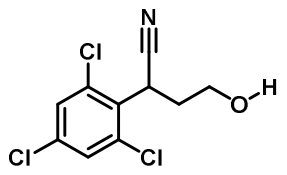

$2 t$

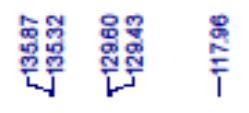

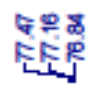

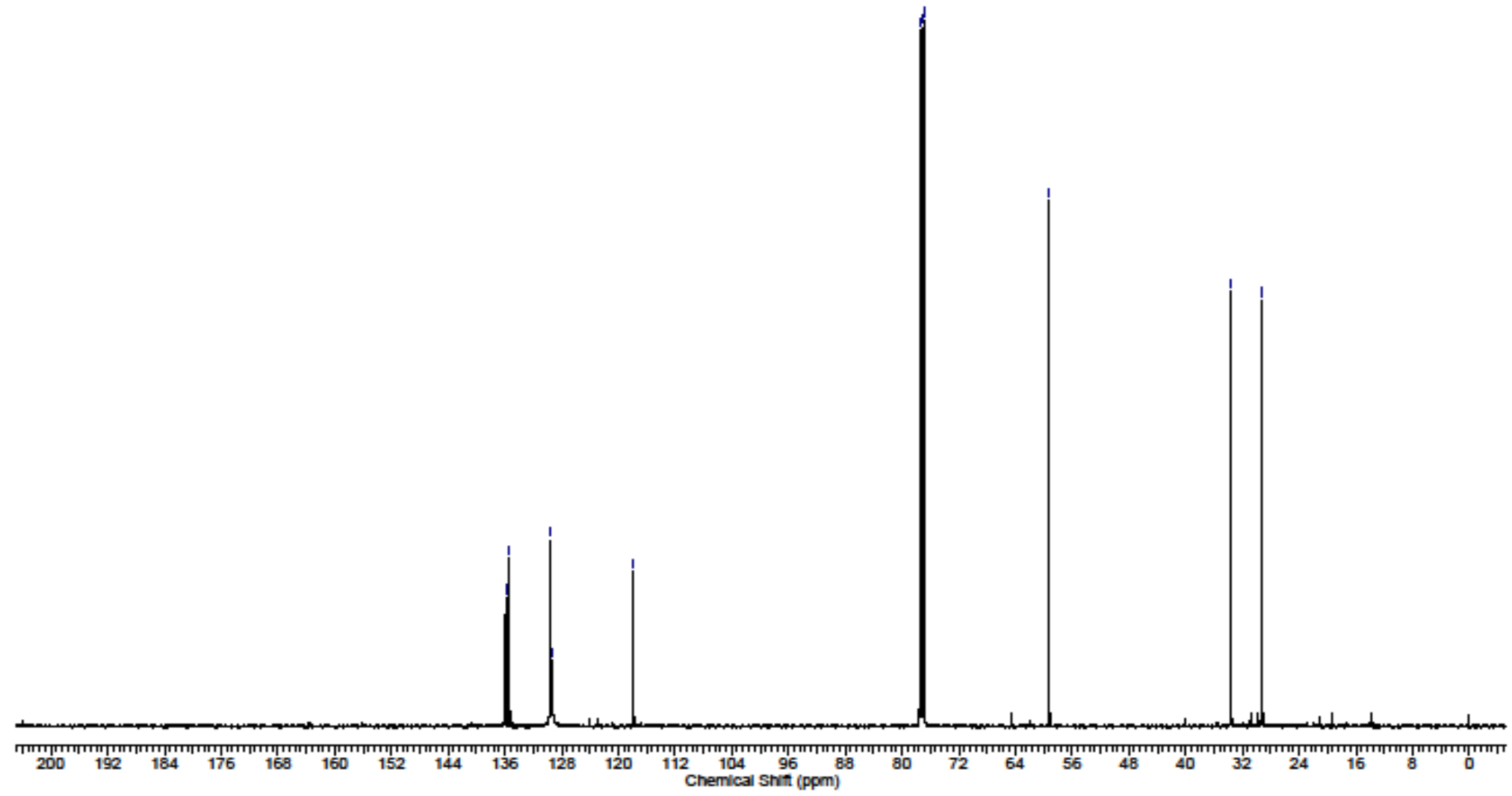


${ }^{1} \mathrm{H}$ NMR spectrum of $\mathbf{2 w}$ in $\mathrm{CDCl}_{3}$ with $0.05 \% \mathrm{v} / \mathrm{v}$ TMS (400 MHz)

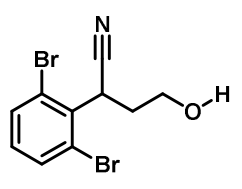

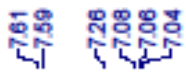

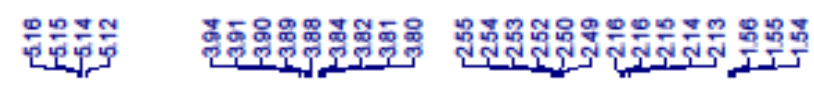

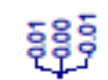

2w
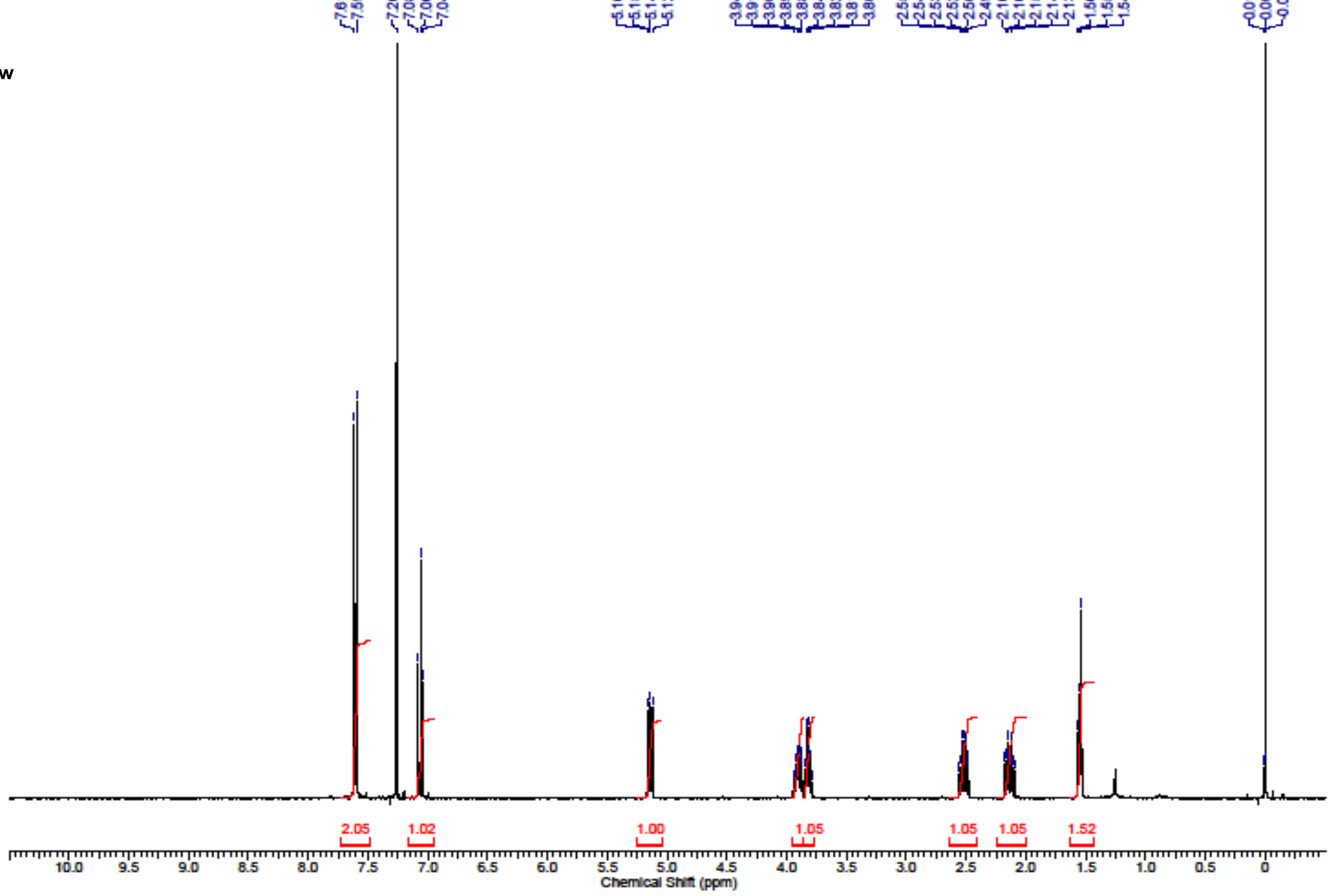
${ }^{13} \mathrm{C}\left\{{ }^{1} \mathrm{H}\right\}$ NMR spectrum of $\mathbf{2 w}$ in $\mathrm{CDCl}_{3}$ with $0.05 \% \mathrm{v} / \mathrm{v}$ TMS $(100 \mathrm{MHz})$
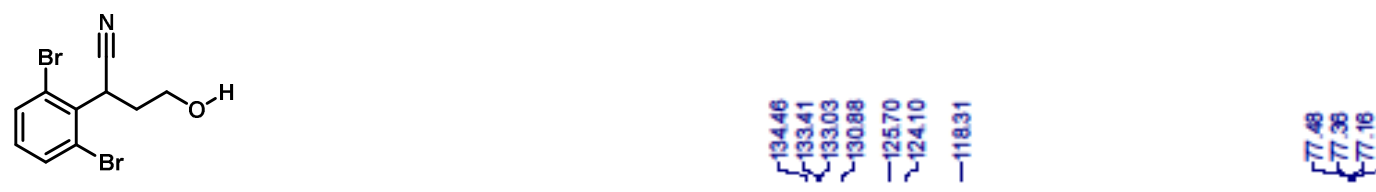

雬要

$2 w$

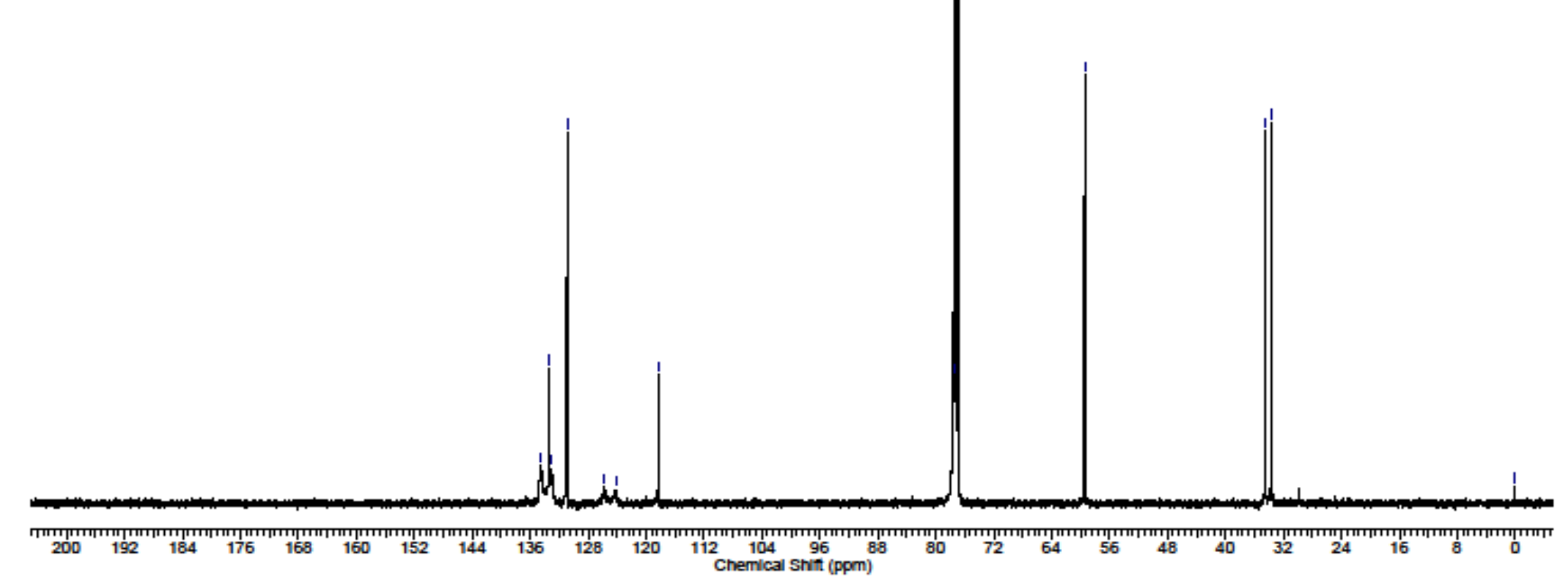




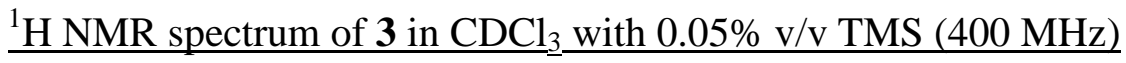

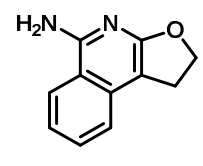

3

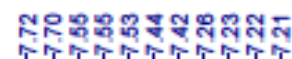

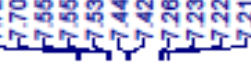

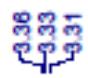

$\stackrel{\square}{\uparrow}$

$\stackrel{8}{i}$

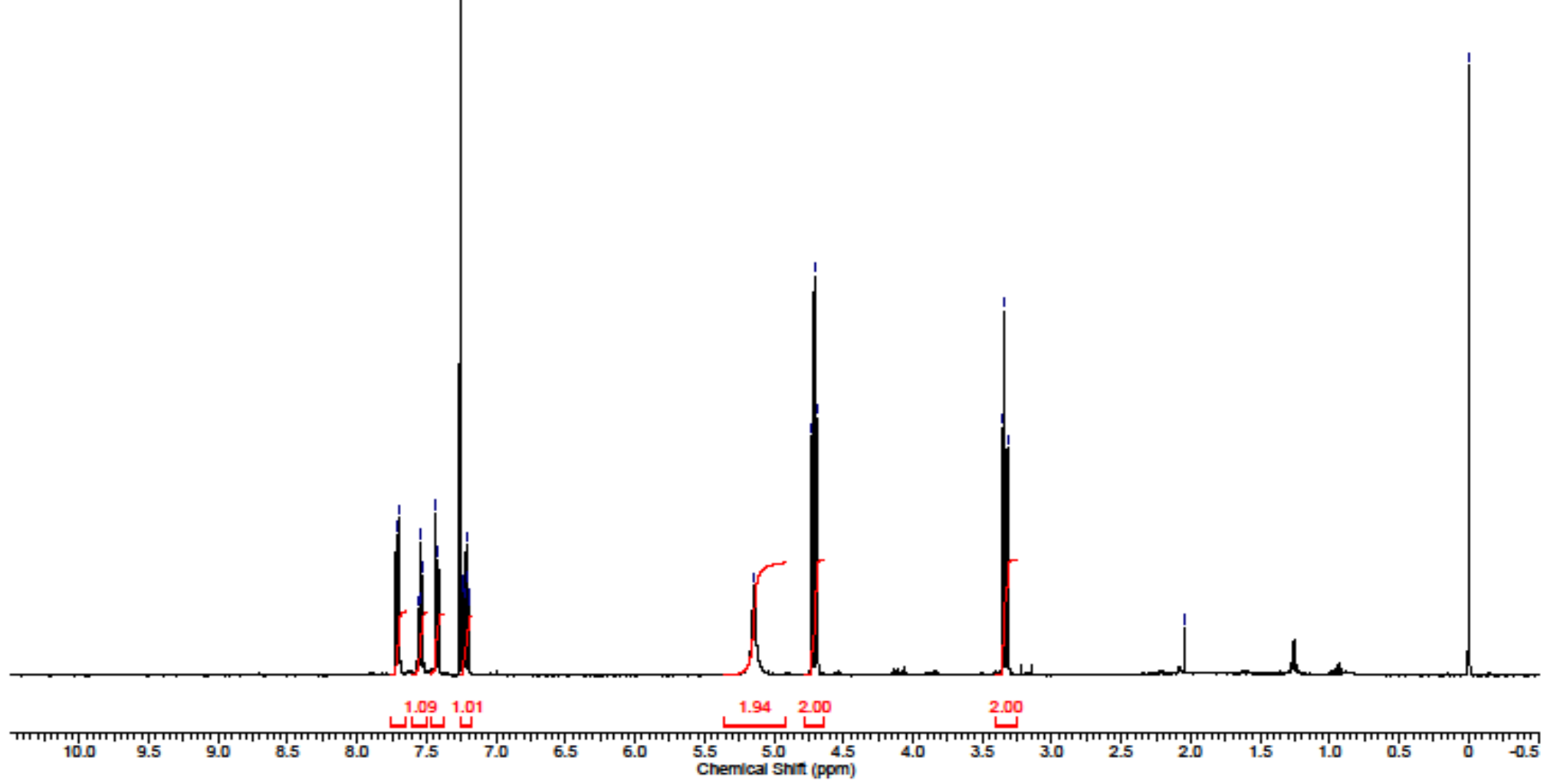

S83 
${ }^{1} \mathrm{H}$ NMR spectrum of 4 in $\mathrm{CDCl}_{3}$ with $0.05 \% \mathrm{v} / \mathrm{v}$ TMS (400 MHz)

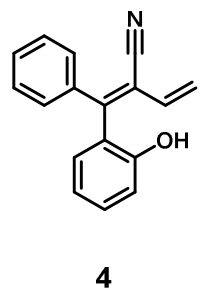

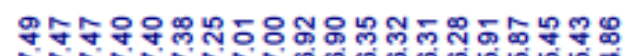

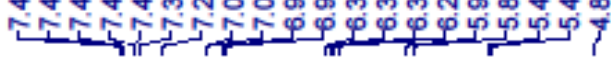

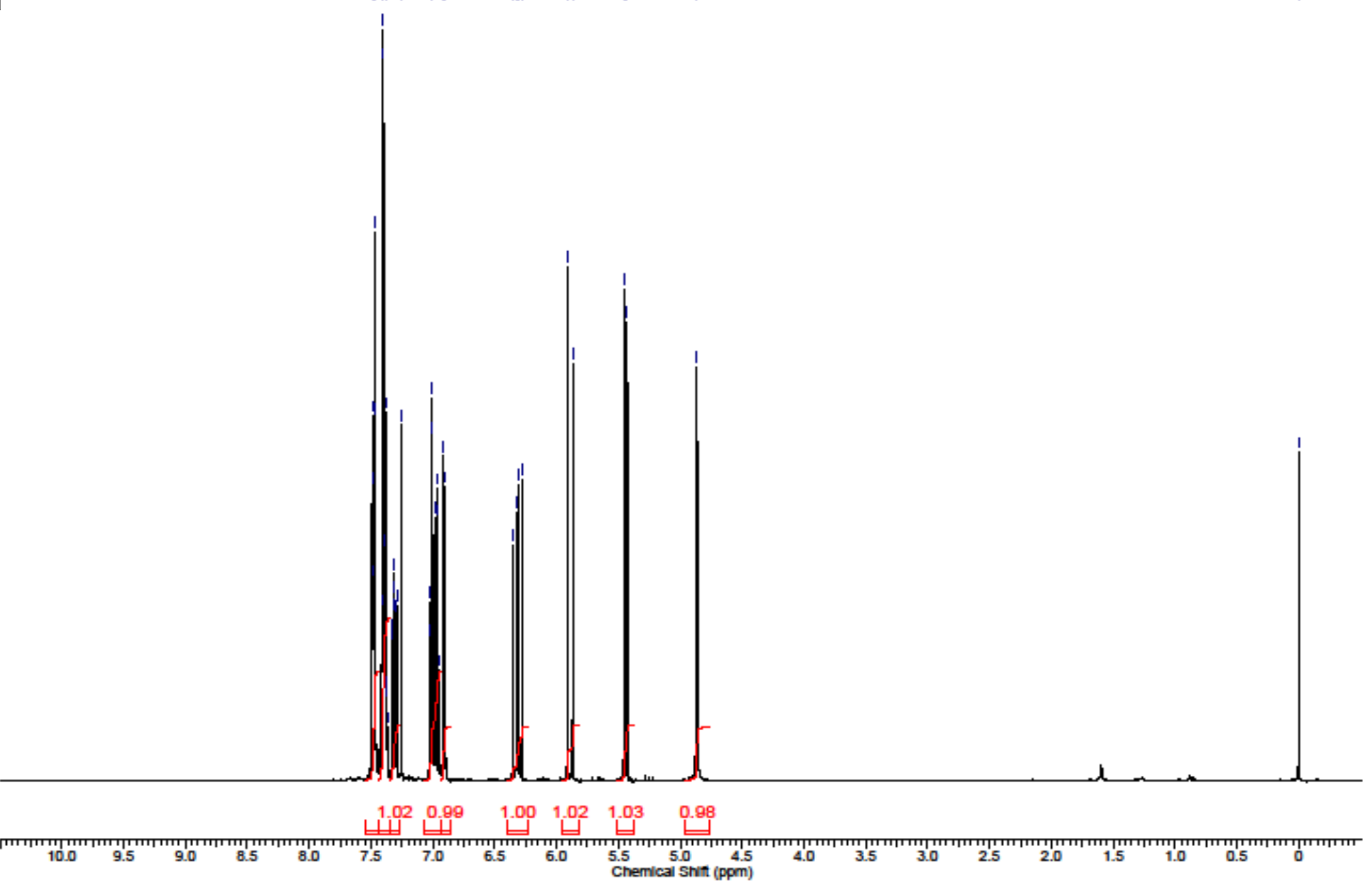


${ }^{13} \mathrm{C}\left\{{ }^{1} \mathrm{H}\right\}$ NMR spectrum of 4 in $\mathrm{CDCl}_{3}$ with $0.05 \% \mathrm{v} / \mathrm{v}$ MS $(100 \mathrm{MHz})$

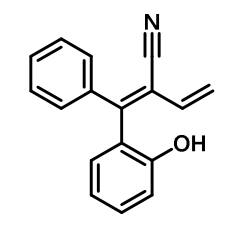

4
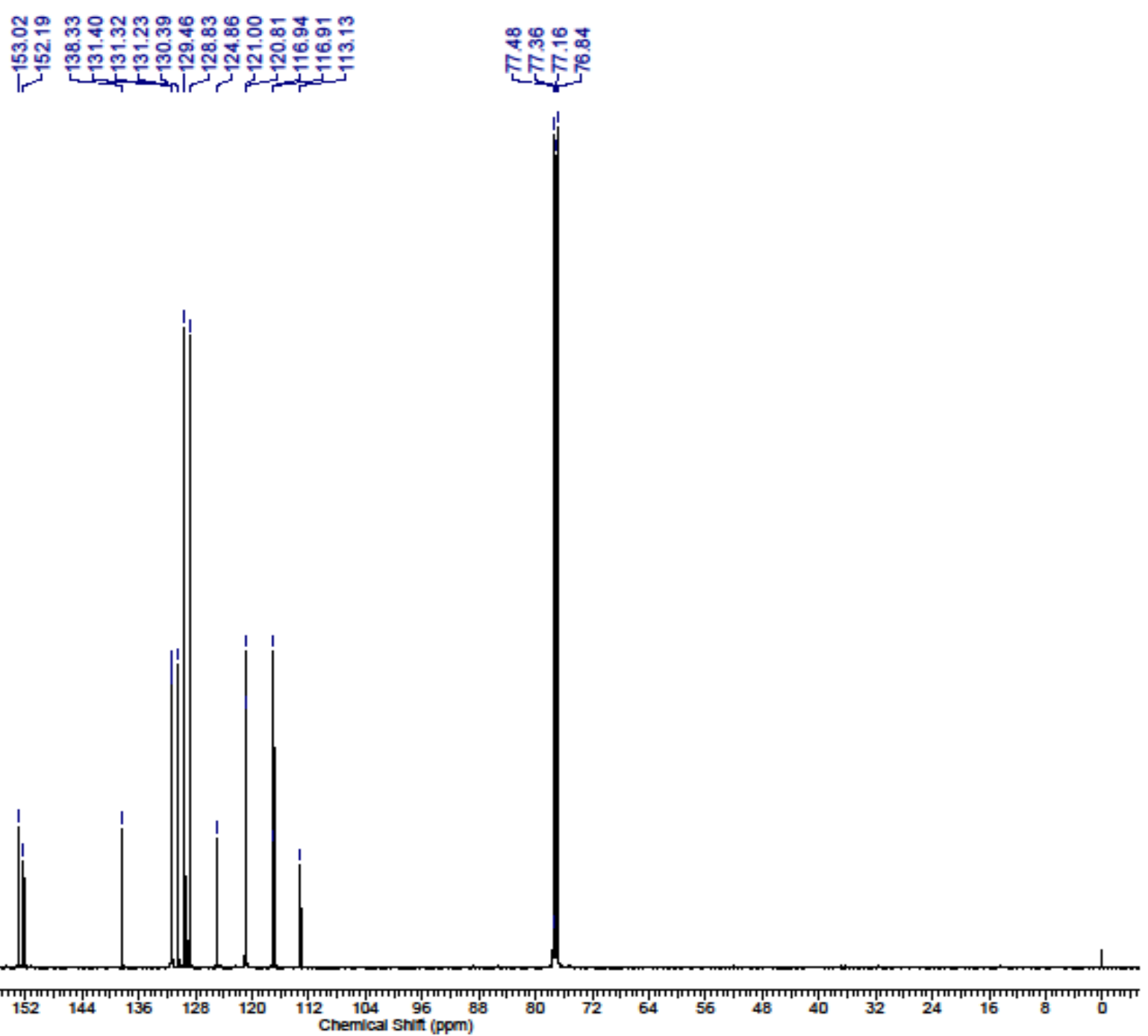

S85 
${ }^{1} \mathrm{H}$ NMR spectrum of 5 in $\mathrm{CDCl}_{3}$ with $0.05 \% \mathrm{v} / \mathrm{v}$ TMS (400 MHz)

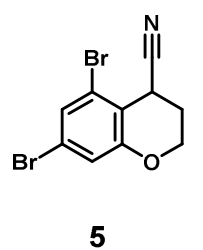

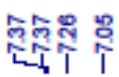

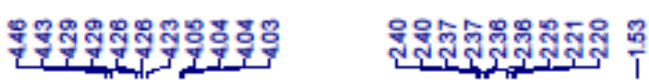

5

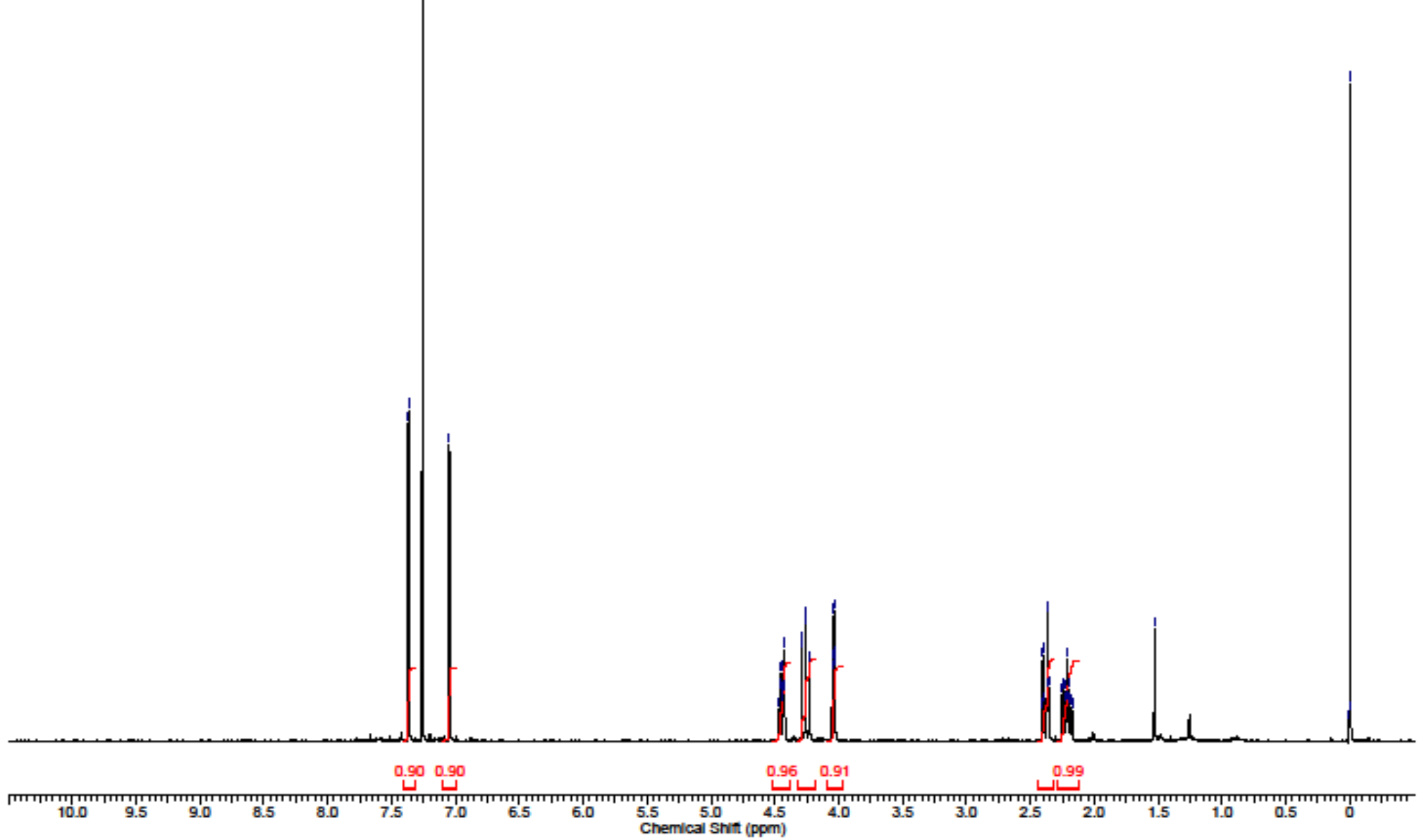




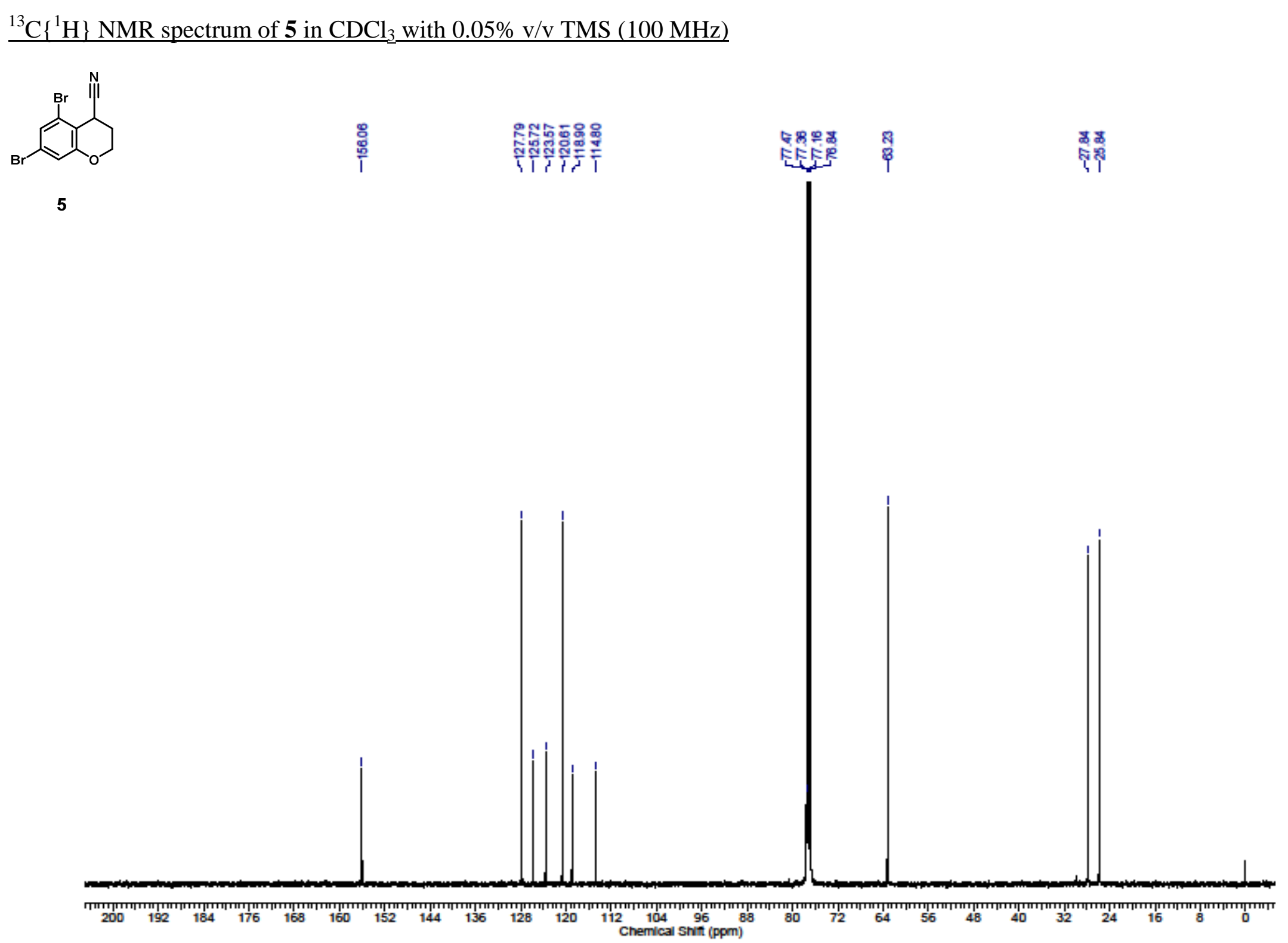

S87 
${ }^{1} \mathrm{H}$ NMR spectrum in $\left(\mathrm{CD}_{3}\right)_{2} \underline{\mathrm{SO}}$ with $0.05 \% \mathrm{v} / \mathrm{v}$ TMS $(400 \mathrm{MHz})$

In situ observation of Meisenheimer intermediate (NOTE: 1a annotated with *)

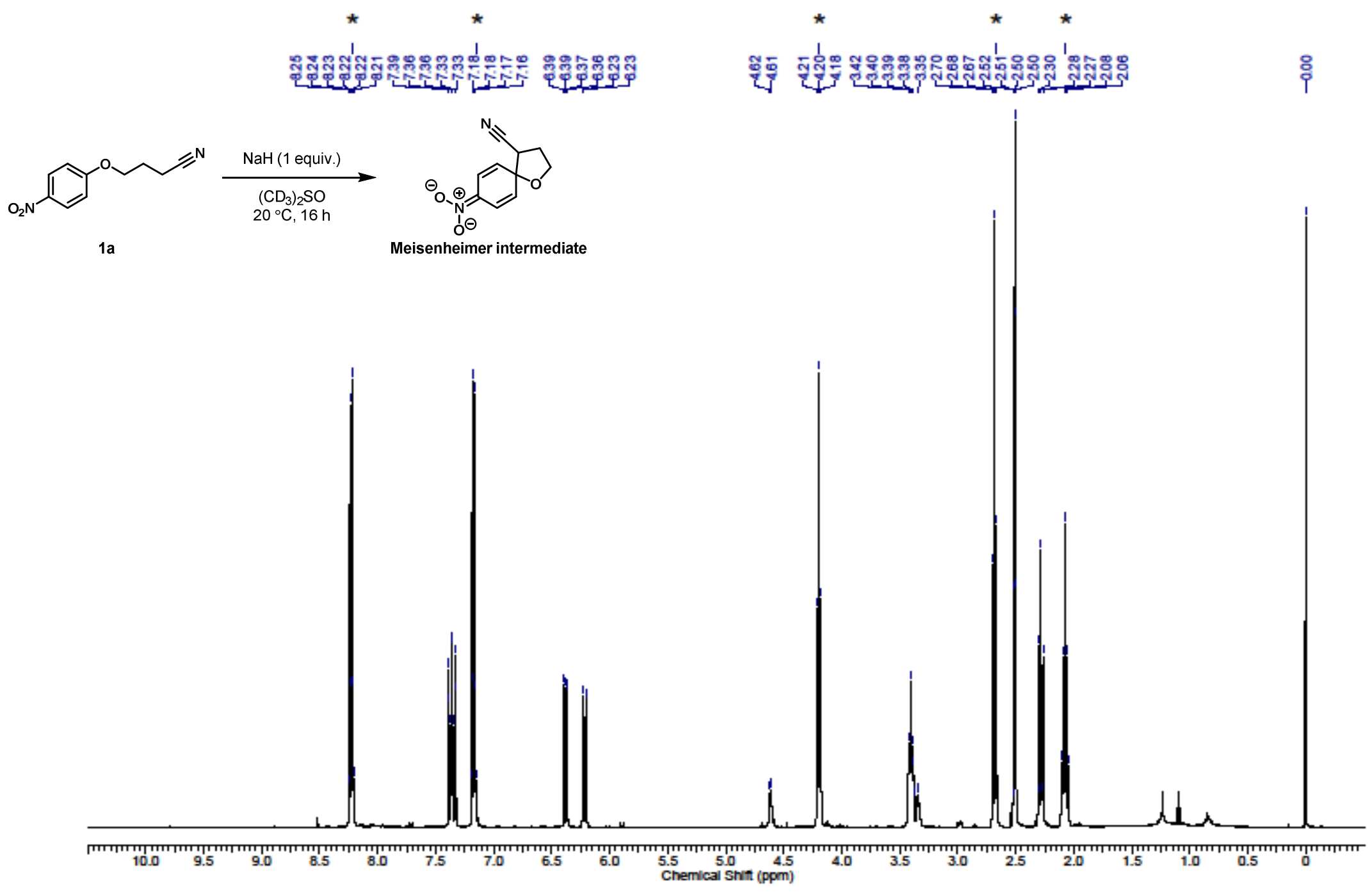


${ }^{13} \mathrm{C}\left\{{ }^{1} \mathrm{H}\right\}$ NMR spectrum in $\left(\mathrm{CD}_{3}{ }_{2} 2 \underline{\mathrm{SO}}\right.$ with $0.05 \% \mathrm{v} / \mathrm{v}$ PMS $(100 \mathrm{MHz})$

In situ observation of Meisenheimer intermediate (NOTE: Ia annotated with *)

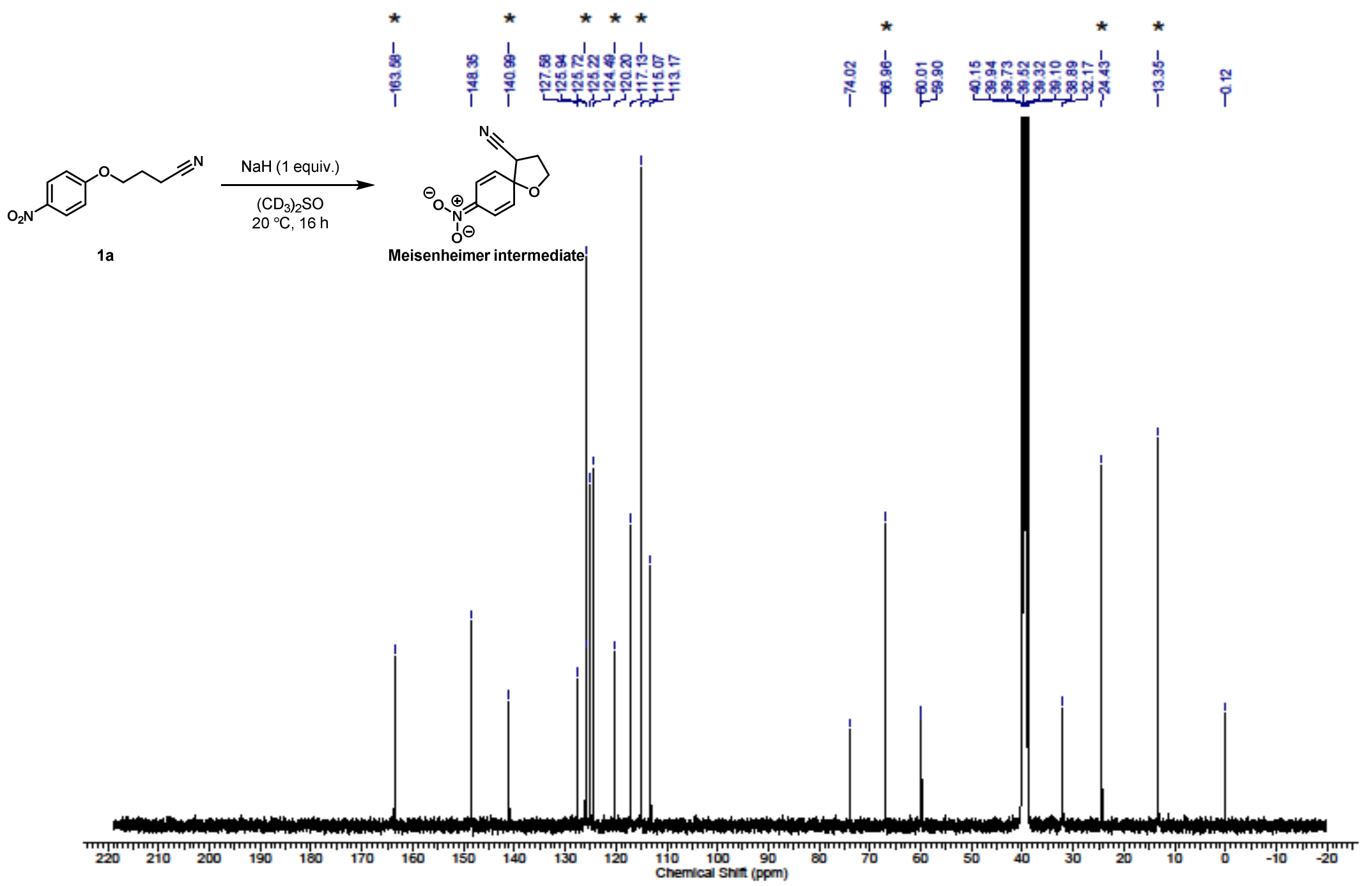

S89 